Claremont Colleges

Scholarship@ Claremont

CGU Theses \& Dissertations

CGU Student Scholarship

1977

\title{
Valentin Roeser's Essay on the Clarinet (1764) Background and Commentary
}

Albert Richard Rice

Claremont Graduate University

\section{Recommended Citation}

Rice, Albert Richard. (1977). Valentin Roeser's Essay on the Clarinet (1764) Background and Commentary. CGU Theses \& Dissertations, 103. http://scholarship.claremont.edu/cgu_etd/103. doi: $10.5642 /$ cguetd/103

This Open Access Master's Thesis is brought to you for free and open access by the CGU Student Scholarship at Scholarship @ Claremont. It has been accepted for inclusion in CGU Theses \& Dissertations by an authorized administrator of Scholarship @ Claremont. For more information, please contact scholarship@cuc.claremont.edu. 
VALENTIN ROESER'S ESSAY ON THE CLARINET (1764), BACKGROUND AND COMMENTARY

ALBERT RICHARD RICE ip

CLAREMONT GRADUATE SCHOOL 


\section{TASTE CF CONTENAS}

Chapter

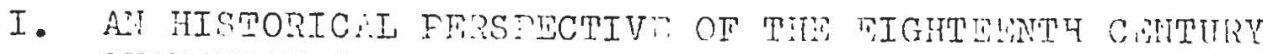

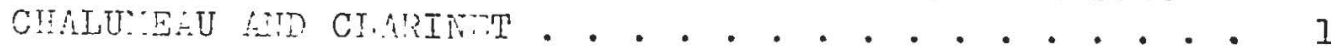

Iconographical evidence for the existence of single-

reed chalumeaux in the sixteenth century ..... . 3

Sixteenth - and seventeenth-century descrintions of

the chalumeau. . . . . . . . . . . . 10

The Mock trurnet . . . . . . . . . . . 17

The eighteenth-century chalumeau . . . . . . . 23

The two-key clarinet . . . . . . . . . 38

The music of the two-key clarinct. . . . . . . 61

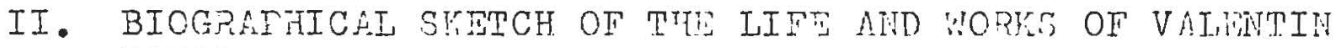

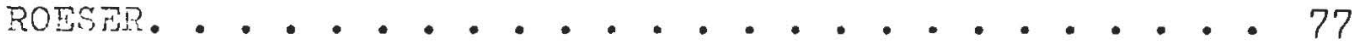

Life . . . . . . . . . . . . . . 77

Works....................... 82

III. AIT FNGIISH TRATSLRTION OF THE ESSAI D'INSTRUCTION,

PART OHE: COHCERNING THE CLRRINET • • • • • • • • • • • 91

IV. COMENTRRY OH THE FHYSICAL, MUSICAL AID IFDAGOGICAL

CONTENT OF TYT ESSAI D'INSTRTCTION. • • • • • • • • 116

Part one: the types of clarinets that are used . . 120

Part two: the types of clarinets most often used and

the tone quality of different clarinets. . . . . 121

Part three: the range of the clarinet. . . . . 125

Part four: the types of sound within the range of

the clarinet............ . . . . 129 
Fart five and six: tables of unisons demonstrating

transposition and an explanation of transposition. - 130

Fart seven: the most favorable keys on the clarinet. 131

Part eight: indexes and examples of transposition of

all the clarinets. . . . . . . . . . . 132

Part nine: mar'inf the kind of clarinet to be used

in the score... . . . . . . . . . . 132

Part ten: the four keys of the clarinet. . . . . 132

Fart eleven: passages that cannot be played as

slurred notes. . . . . . . . . . . . . 133

fart twelve: trills............. . 134

Part thirteen: articulation of sixtecnth notes . . 134

Fart fourteen: a general rule for composers. . . 136

ABBREVIATIONS USED IN THE APPENDIXES. . . . . . . . . . . 137

ADPENDIX

A. Abbreviations of reference sources used in appendixes

A and B. . . . . . . . . . . . . . 138

A LIST OF YUSICAL HORKS USING TUE CHILUNEAU • • . . • 141

B. A LIST OF MUSICAL UORTS USING TIE TOO-KEY CLARINET. • . 153

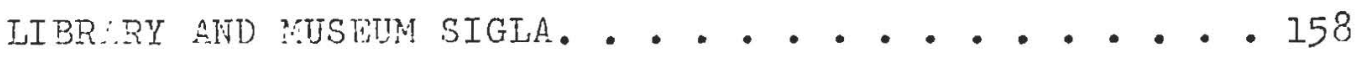

C. A CIROHOLOGICAL IIOTISG OF IMGRUCTIOHAL MATERI ALS FOR

TIE FIGHTEENTH CENTURY CHALUSRAU ATD CIARIHUT • • • • 160

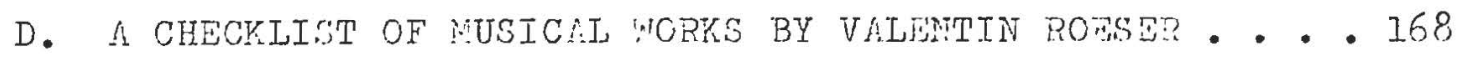

\section{BIBIIOGRAPHY}

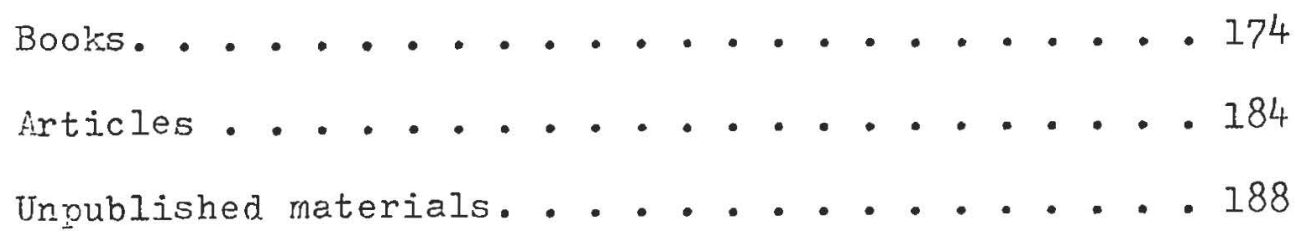




\section{TABLE OF PLATES}

1 A woodcut impression of "Burcundian fifers" from the Triumphzug Kaiser Waxmilian's comniled in 1519, modern edition, Hans Burekmair, The Triumph of Maximillian I (New York: Dover, 1964), plate 79.......... .

2 The plate entitled "usica" from Jost Amman's Wapinenund-Stammbuch (Franckfort am liain: Sicm Feyrabend, 15\%, reprint ed., Munchen: Hirth, 1893), 111........

3 is painting on an altar in the Stadtkirche in Bitterfeld, East Germany (c. 1525), from Herbert Heyde, "Ein Urahn der Klarinette?" Deutsches Jahrbuch der Kusikwissenschaft fur 197015 (1971): illustration one . . . . . .

4 is section of the painting (plate 3 ) on an altar in the Stadtkirche in Bitterfeld, East Germany (c. 1525), from Herbert Heyde, "Iin Urahn der Klarinette?" Deutschcs Jahrbuch der Musikwissenschaft fur 197015 (197) : illustration two....................... 9

5 Chalumeau instruments illustrated in Marin Mersenne, Ilarmonie Universelle (Paris: S. Cramoisy, 1636): The Books on Instruments, trans. by Roger i. Chapman (The Hague: Martinus Nijhoff, 1957), 299 . . . . . . . . . 13

6 A Chalemie or Cornemuse from Marin Mersenne, Harmonie Jniverselle (Faris: S. Cramoisy, 1636): The Books on Instruments, trans. by Roger E. Chapman The Ilague: Martinus Nijhoff, 1957), 355. . . . . . . . . . 15

7 A fingering chart for the mock trumpet from The Fourth Compleat Book for the Mock Trumpet (London: J. Walsh, J. Hare, and P. Randall, c. 1707), [iii] . . . . . 20

8 A keyless soprano chalumeau from the Encyclopédie... Recueil de Tlanches (Paris: Briasson, David, Le Breton, 1767), vol.5, plate 8.............. 36

9 The earliest representation of a clarinettist from Johann Christoph :eigle, Musicalisches Theatrum (Iturnberg: J.C. Weirile [before 1726], facsimile ed., ed. by Alfred Berner, Kassel: Burenreiter, 1961), blatt 14. . 45 
10 The earliest illustration of a fingering chart for the two-key clarinet from J.F.B.C. Majer, Museum Musicum (Schwab. Hall: Geor Nichael Kajer, 173?, facsimile ed. ed. by Heinz Becker, Kassel und Basel: Burenreiter,



11 Fingering chart for the two-key clarinet from [Johann Philipp Eisei], Musicus Autodidaktos (Erfurt: Johann Michael Funcken, 1738), 79............. 51

12. An announcement in the Dublin Mercury of Mr. Charles'

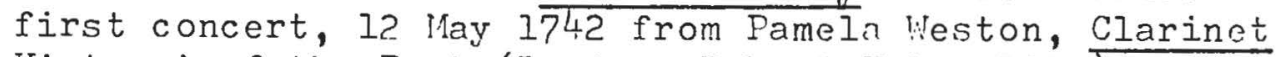
Virtuosi of the Past (Iiondon: Robert Fale, 1971), 23. 54

13 A two-key clarinet from the Encyclopédie... Recucil de Planches (Paris: Briasson, David, Le Breton, 1767), vol.5, plate 3................. 56

$14 \Lambda$ two-key clarinet in hifh From F.A.P. de Garsault, Notionaire, ou mémorial raisonné (Faris: Guillaume Desprez, 1761), 646. .............. 58

15 The second edition (c. 1717 to 1722) of the first known works written for the clarinet, Bibliotheque $d u$ Conservatoire Royal de Musique, Brussels (classmark 5606) 62

16 A portion of the clarinet part from the first movcment of the Trio for Clarinet, Cornu de Schass et Basso by Kulbel, Hessische Landes-und Hochschulbibliothek, Darmstadt (Mus. 1181 ). ................. 70

17 Clarinet part of the Concerto in A major by Johann Melchior Molter, Badische Landesbibliothek, Karlsruhe (Ms. 304). . . . . . . . . . . . . 73

18 First violin part from the third symphony of opus four by Valentin Roeser from Barry S. Brook, La jymphonie Française dans la Seconde Vioitié du XVIIT Sidcle, 3 vols. (Paris: Publications de l'Institut de Nusicologie de l'Université de Paris, 1962), 1: 230........ 89

19 The title page of the 1764 edition of the Essai d'Instruction from MGG (1957), s.v. "Instrumentation," by Ludwig K. Mlayer, 6: cols. 1261-1262. . . . . . . . . . . 117 
20 I four-ley clarinet from the Encyclopédie.. . Suite de Recueil de Planches (laris: Fanckouche, Stoupe, Srunet, 1777), 143, supplemental plate 4.......... . 124

21 If fingering chart for the five-rey clarinet from Amand Vanderhagen, Méthode Nouvelle et Raisonnée pour la Clarinette (Paris: Boyer et Le lienu, c. 17\%5, reprint ed., Genève: Inkoff Reprint, 1972), ?......... 128 


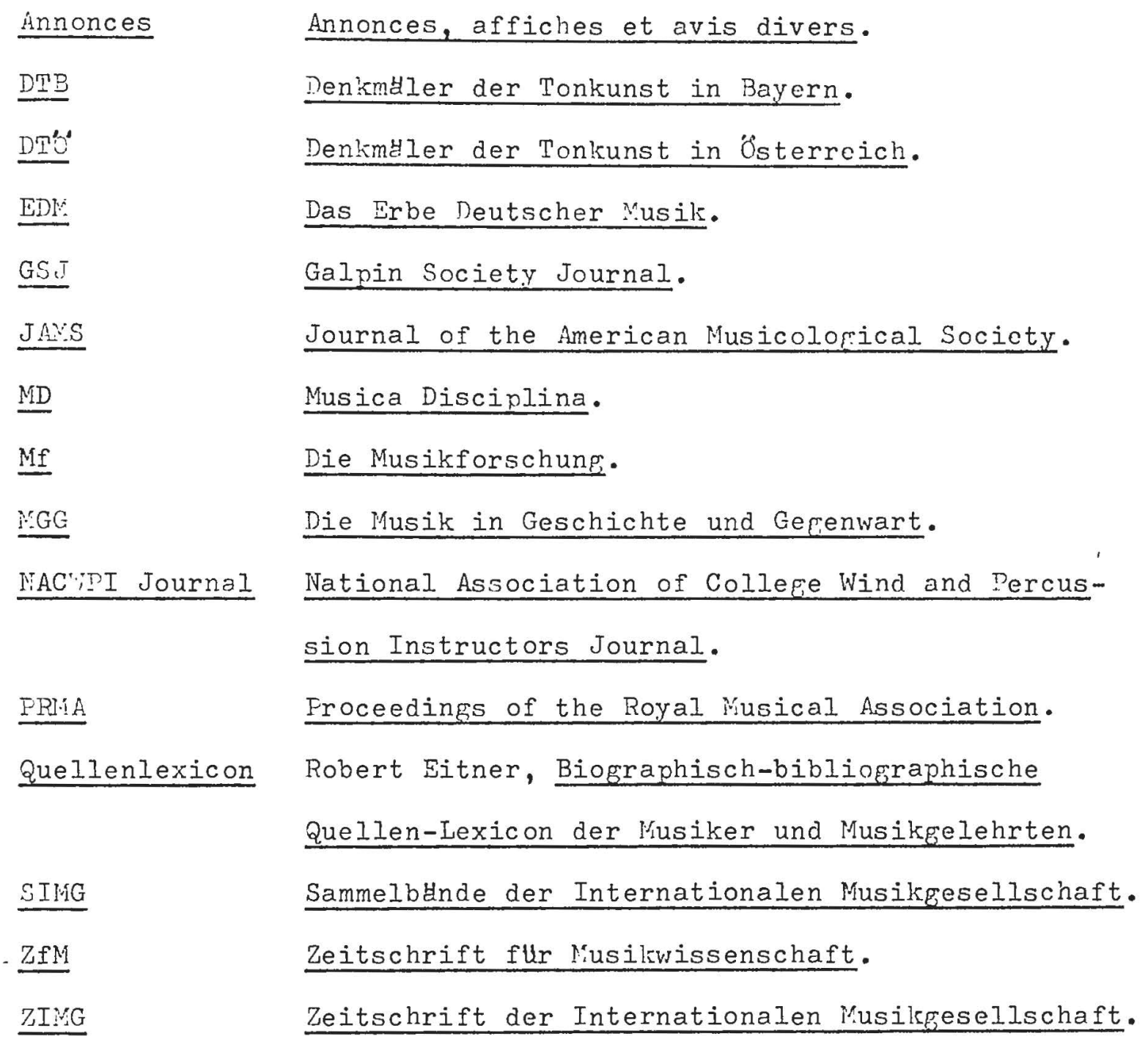




\section{CHAFTER I}

\section{AN HISTORICAI PERSPECTIVE OF THE EIGHTEENTH-CENTURY CHALUWEAU AND CLARINET}

At the beginning of the eighteenth century, the sudden appearance of the chalumeau ${ }^{l}$ and the clarinet on the European musical scene proved to be historically important for the development of modern orchestration. By the time that Roeser had written his Essai (1764), the clarinet was considered a valuable addition to the supply of wind instruments available to the composer. At the end of the eighteenth century, it was firmly established as a leading woodwind in the symphony orchestra; and was further popularized by several well-known soloists. This chapter will outline the chalumeau's and clarinet's historical and musical development through the eighteenth century to place Roeser's Issai in a clear perspective. A review of the scholarly evidence for the use of a European single-reed chalumeau in art music, before 1704, prefaces this outline. The double pipes of antiquity and such ancestral and modern-day folk instruments as the zummârah, argouhl, launedda and hornpipe will

$I_{\text {This term is usually interpreted to signify a double-reed }}$ instrument or shawm before the eighteenth century. During the eighteenth century it was known as a single-reed instrument. 
not be discussed, since thorough discussions of these instruments are given in Marcuse, ${ }^{2}$ Sachs, ${ }^{3}$ Hickmann, ${ }^{4}$ Rendall, ${ }^{5}$ and Baines. 6

During the middle ages, the terms used for reed pipes were first recorded in the French literature of the twelfth century in a variety of forms. Subsequently, various words in several languages were used for this purpose, e.g.; chalemie, chalemel, calemel, chalumeau, kalemele, schalmey, scalmeye, and shawm. A common derivation appears to be from the Latin calamus ${ }^{7}$ or the Greek kalamos, 8 both meaning "reed". These terms could have been used to indicate instruments having a reed as a mouthpiece, flutes made of reed, pan-pipes, the chanters of bagripes, or "reed-pipes" in a general sense. Sachs states that "reed pipes in the strict

2 Sibyl Marcuse, A Survey of Musical Instruments (New York: Harper \& Row, 1975), 651-673.

${ }^{3}$ Curt Sachs, The History of Musical Instruments (New York: W.W. Norton, 1940), 91-92.

${ }^{\mathrm{MGG}}$ (1958), s.v. "Klarinette: B. Die aussereuropHischen und antiken Klarinetten instrumente. Vor- und Fruhgeschichte," by Hans Hickmann, 7: cols. 993-1005.

5 Frank Geoffrey Rendall, The Clarinet, $3 d$ ed., rev. and with some additional material by Philip Bate (New York: W.W. Norton, 1971), 62-64.

${ }^{6}$ Anthony Baines, Woodwind Instruments and Their History, $3 \mathrm{~d}$ ed. (London: Faber and Faber, 1967), 194-204.

7 Sachs, 288

$8_{\text {Encyclopaedia Britannica, }}$ llth ed., s.v. "Clarinet," by Kathleen Schlesinger. 
sense of the word seem to have been oboes; no source, pictorial or literary, refers to a clarinet". 9 He then describes two types of medieval oboe instruments that were used as a loud and soft variety. 10 By the thirteenth century, a rudimentary single-reed was being used in the chanter of the bladder pipe variety of bagpipes. 11 Therefore, at this time it is certain, that the ancient method of forming a single-reed from the body of a tube, was used in a more complicated instrument. The more difficult question is one of ascertaining when a single-reed instrument was used by itself in European art music.

Iconographical evidence for the existence of single-reed chalumeaux in the sixteenth century

Schlesinger cited two pictorial examples of a single-reed chalumeau from the sixteenth century. ${ }^{12}$ The first is found in plate seventy-nine of the woodcut impressions made for the Triumphzug Kaiser Maxmilian's compiled in 1518; first edition pub-

${ }^{9}$ Sachs, 288 .

${ }^{10} \mathrm{Cf}$. Edmund Bowles, "Haut and Bas: The Grouping of Musical Instruments in the Middle Ages," MD 8 (1954): 115-140. Bowles seems to overlook his own evidence in the medieval poetry cited by designating the chalumeau as only a loud reed pipe. The poem Dumars de Galois has "chalemel" together with the soft "flahutes".

${ }^{11}$ See, Sachs, 283 .

12 Encyclopaedia Britannica, 439-440. 
lished in $1526 .{ }^{13}$ This plate is reproduced here and illustrates ten men on horseback; the initial group of five playing instruments that resemble the wind-capped rauschpfeife. ${ }^{14}$ The second group play an instrument that appears to have the same cylindrical bore as the rauschpfeife, only it is shorter in length. This instrument could have a single-reed mouthpiece but it cannot be clearly identified from the plate. An English translation of the accompanying descriptive text follows.

\section{BURGUNDIAN FIFERS}

After them shall come on horseback Burgundian fifers in the Burgundian colors with bombardons, shawms, and rauschpfeiffen. And they shall all be wearing laurel wreaths. 15

The illustration of the plate seems to verify an identification of the rauschpfeiffen and shawms. Bombardons or large shawms seem to be missing and may have been mistakenly left out of this plate. Because these instruments are played by "fifers" on horse-

${ }^{13}$ See, Hans Burgkmair, The Triumph of Maximillian I, trans. of text by Stanley Appelbaum (New York: Dover, 1964), 9; plate 79. ${ }^{14}$ See, Sachs, 323 .

${ }^{15}$ Burgkmair, trans. by Stanley Appelbaum, 9. This plate has been attributed to Albrecht Altdorfer on stylistic grounds, see, Joseph Meder, Durer-Katalog Ein Handbuch Hber Albrecht Durer's Stiche, Radierungen, Holzschnitte, deren Zustünde, Ausgaben und Wasserzeichen (Wien: Gilhofer und Rauschburg, 1932). 
A woodcut impression of "Burgundian fifers" from the Triumphzug Kaiser Maxmilian's compiled in 1518, modern edition, Hans Burgkmair, The Triumph of Maximillian I (New York: Dover, 1964), plate 79.

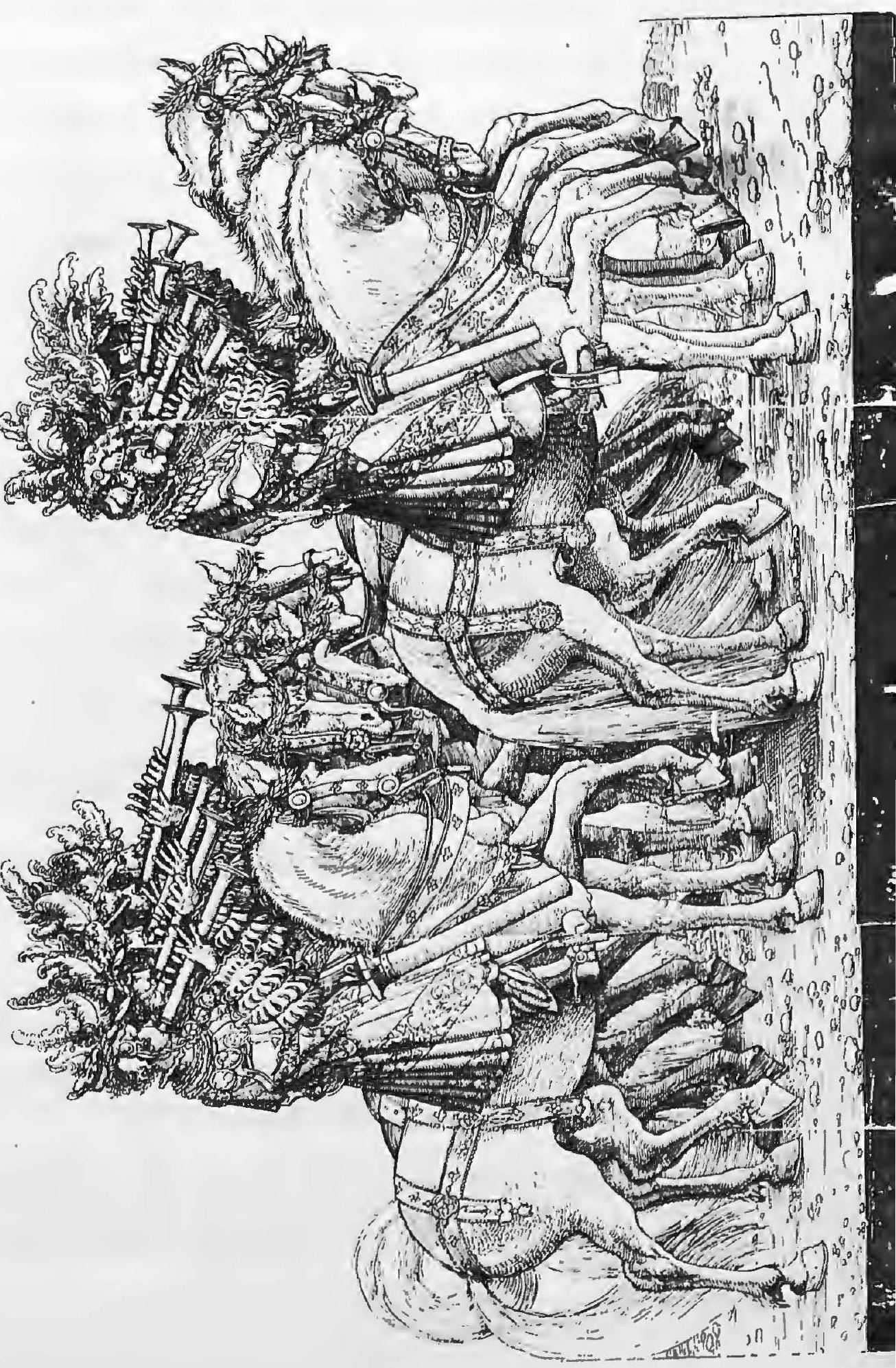


back rather than noblemen on trailers in the procession; it would seem to indicate that they were used in outdoor military activities, rather than in art music.

The second examle cited by Schlesinger appears on a nlate entitled "Musica" in Jost Amman's Wappen-und-Stammbuch (15.99), page 111. 16 she describes this example as a smaj.l, primitive chalumeau similar to the reproduction exhibited at the Royal Vilitary Exhibition in London in 1890. ${ }^{17}$ However, the plate itself reveals the instrument to be a recorder (see, plate two). A final iconographical example is found in the stadtkirche in Bitterfeld, East Germany. It is described by Heyde as a painting on the wing of the altar, of the southern side of the chapel. 18 Here, Job is portrayed as a leper and a woman is cleansing him by pouring water over his head. Three musicians are playinp instruments that appear to be made of metal, are shaped in the form of a clarino or natural trumpet, and have a clarinet-like mouthpiece. An illustration of this painting seems to confirm this description (see, plates three and four). On the basis of the style of the

16 Jost Amman, Wappen-und-Stammbuch (Franckfort am Main: Sigm. Feyrabend, 1589; reprint ed., Munchen: Hirth, 1893).

${ }^{17}$ See, Charles Russell Day, A Descriptive Catalogue of the Musical Instruments Recently Exhibited in the Royal Military Exhibition, London 1890 (London: Eyre \& Spottiswoode, 1891), pl. iv A; 110, no. 221, as quoted in Encyclopaedia Britannica, 439.

18 Herbert Heyde, "Ein Urahn der Klarinette?" Deutsches Jahrbuch fur Yusikwissenschaft fur 1970, 15 (1971): 121-124. 
PLATF. 2

\section{MVSICA.}

:Mancher fith fehnen thut naç freud/ Dir jnt boh bringt groE Eqertier litot.
Dnd thut fein Ecib/ Gut/ Scel bejgrwernt/

Ditd all fein glimpif und Ehr Derferts.

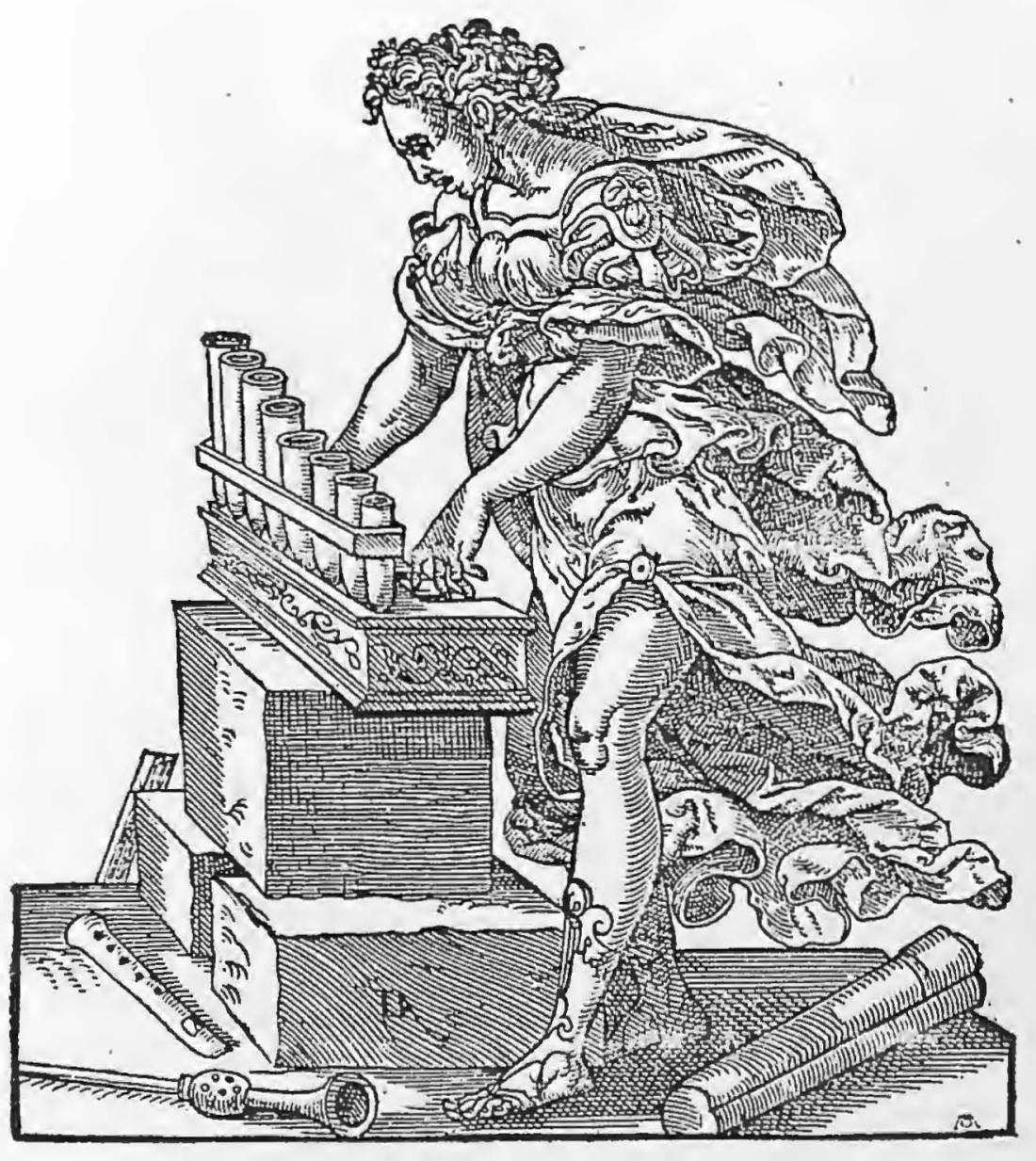

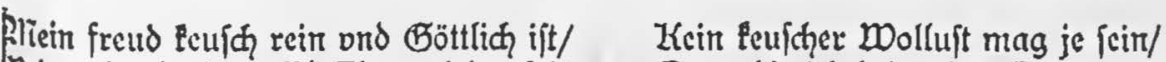
Sringt lujt/ fhimpff/ Ehr ju jeour frift. Dann dic id bring den Dienerm nein:

The plate entitled "Musica" from Jost Amman's Wappen-und-Stammbuch (Franckfort am Main: Sigm. Feyrabend, 1589, reprint ed., Munchen: Hirth, 1893), 111. 


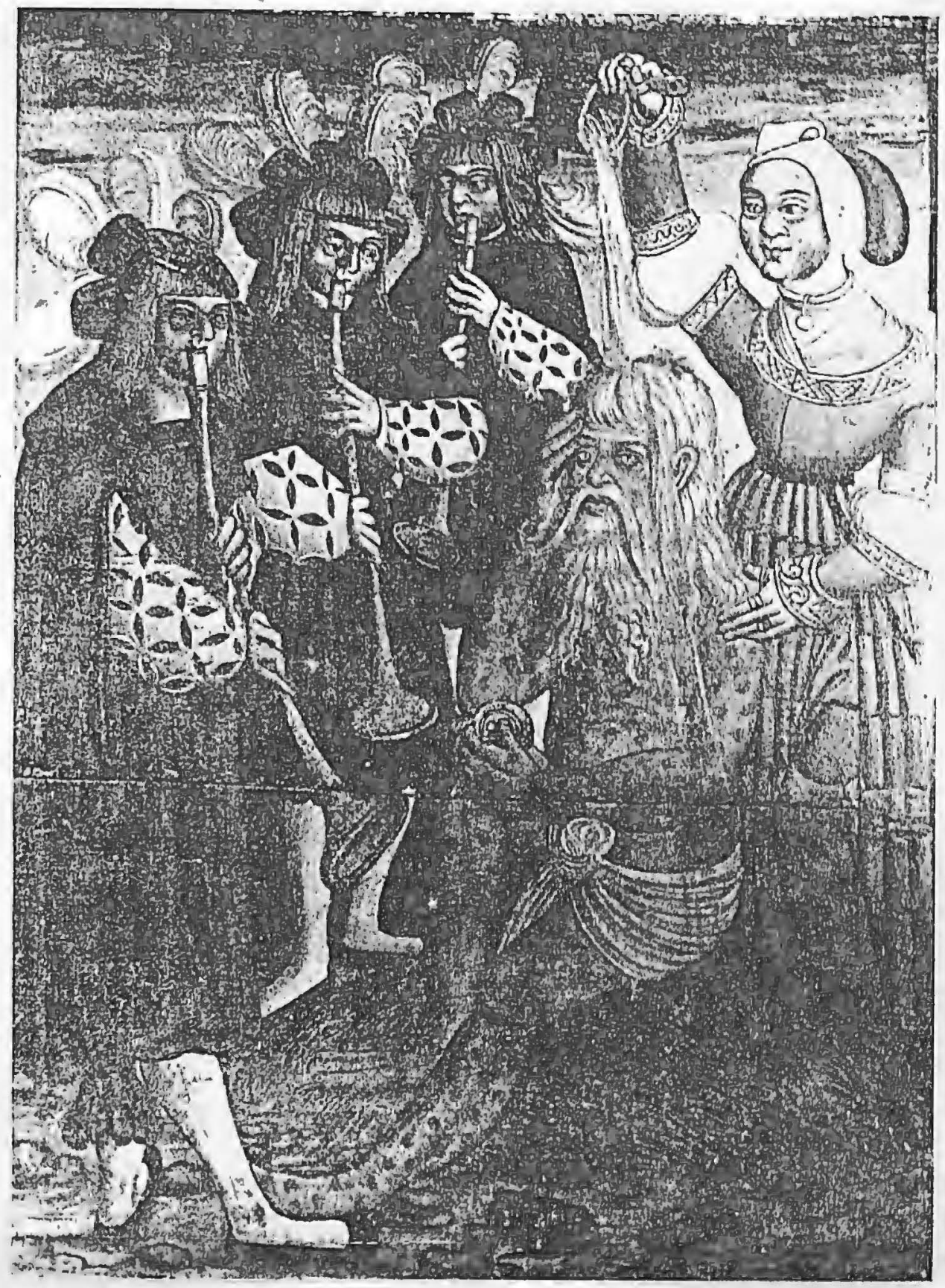

A painting on an altar in the Stadtkirche in Bitterfeld, East

Germany (c. 1525), from Herbert Heyde, "Ein Urahn der Klarinette?"

Deutsches Jahrbuch der Musikwissenschaft fur 1970 15 (1971): il-

lustration one. 




A section of the painting (plate 3) on an altar in the Stadtkirche in Bitterfeld, East Germany (c. 1525), from Herbert Heyde, "Ein Urahn der Klarinette?" Deutsches Jahrbuch der Musikwissenschaft fur 197015 (1971): illustration two. 
costumes that appear in the painting, Heyde dates it as around 1525. Although both this painting and the woodcut from the Triumphzug des Maxmilian's raise interesting questions concerning the use of a single-reed instrument, they still must be considered inconclusive. There are no contemporary written descriptions of such an instrument to substantiate their use in art music.

\section{Sixteenth- and seventeenth-century descriptions of the chalumeau}

No single-reed instrument, with the exception of the regal organ, is found in the instrumental and theoretical treatises of Virdung, ${ }^{19}$ Agricola, 20 Luscinius, 21 and Fraetorius. 22 However, the term chalumeau is found in a variety of general dictionaries

\section{${ }^{19}$ Sebastian Virdung, Musica getutscht und auszgezogen} (Straszburg: Wilhalmen Bischoue, 1511, reprint ed., Kassel: Barenreiter, 1931).

20 Martin Agricola, Musica Instrumentalis Deudsch (Wittenberg: Georgia Rhaw, 1529, reprint ed., Hildesheim: Olms, 1969).

21 Ottmar Luscinius, Musurgia seu Praxis Musicae (Strasburg: Ioannem Schottum, 1536).

22 Michael Praetorius, Syntagma musicum: II. De Organographia (Wolfenbuttel: Elias Holwein, 1619, facsimile ed., ed. by Vilibald Gurlitt, Kassel: Burenreiter, 1958). 
of the sixteenth and seventeenth centuries. In Estienne (1552) it is found under the definition for calamus and described as a "pype or whistle." 23 Desainliens (1593) defined chalumeau as a "reede, a pipe, stemmes of hearbs" 24 and in Nicot (1606) it is defined as a reed or wheat stalk (tuyau de froment). 25 Cotgrave (1611) defined chalumeau as "a small reed, or cane; also, the stemme of an hearbe; also, a wheaten, or oaten straw, or a pipe made thereof". 26 He also provided a definition for chalemelle as "a little pipe made of a reed, or of a wheaten or oaten straw". 27

${ }^{23}$ Robert Estienne, Dictionariolum Puerorium Tribus Linguis Latina Anglica e Gallica (London: Reginaldum Walsium, 1552, facsimile ed., New York: Da Capo, 1971).

${ }^{24} \mathrm{Claude}$ Desainliens, $\$$ Dictionary French and English (London: Thomas Noodcock, 1593, facsimile ed., Menston, England: Scolar Press, 1969).

25 Jean Nicot, Thresor de la Langue Francoise tant ancienne que moderne (Faris: David Doucovr, 1606, facsimile ed., Menston, England: Scolar Press, 1970).

26 Pandle Cotgrave, A Dictionarie of the French and English tongues (London, 1611, reprint ed. with intro. by William s. toods, Columbia: University of South Carolina Press, 1950).

27 Cf. Jeffrey Pulver, A Dictionary of Old English Music \& Nusical Instruments (New York: E.P. Dutton \& Co., 1923), 208. Pulver interpreted this definition and others similar to it as signifying a primitive shawm. 
In Italy, an equivalent word for chalumeau that was used is zamcogna. Florio (1611) defined it as "an Oaten-nipe, Reede-pipe, a sheapheards-pipe". 28

Mersenne also used the word chalumeau, in Harmonie Universelle $(1636)$, as a general term describing reed pipes. 29 However, since part of his work included a compendium of musical instruments, he provided detailed descriptions of several types of reed pipes, and those found as the chanters and drones of bagpipes. Four different types of chalumeaux are illustrated in Proposition IV of the fifth book of wind instruments (plate five). The first is a pipe of willow open at both ends, the second a simple recorder-like instrument without any tone holes. The third and fifth instruments are another popular form of the folk chalumeau made from a wheat stalk or tuyau de ble. They are cut in the middle on the first, and on the upper part on the second, to form a beating tongue (idioglot reed) when air is blown into this opening. The first of these chalumeaux has two tone holes one placed at each end, the second has three tone holes placed at the lower end of the pipe. Mersenne states that "one can make ten or twelve

28 John Florio, Queen Anna's New World of Words or Dictionarie of the Italian and English tongues (London: printed by Melch. Bradwood for Edw. Blount and Hilliam Barret, 1611).

${ }^{29}$ See, Marin Mersenne, Harmonie Universelle (Paris: $s$. Cramoisy, 1636): The Books on Instruments, trans. by Roger E. Chapman (The Hague: Martinus Nijhoff, 1957), 298-299. 
PLATE 5

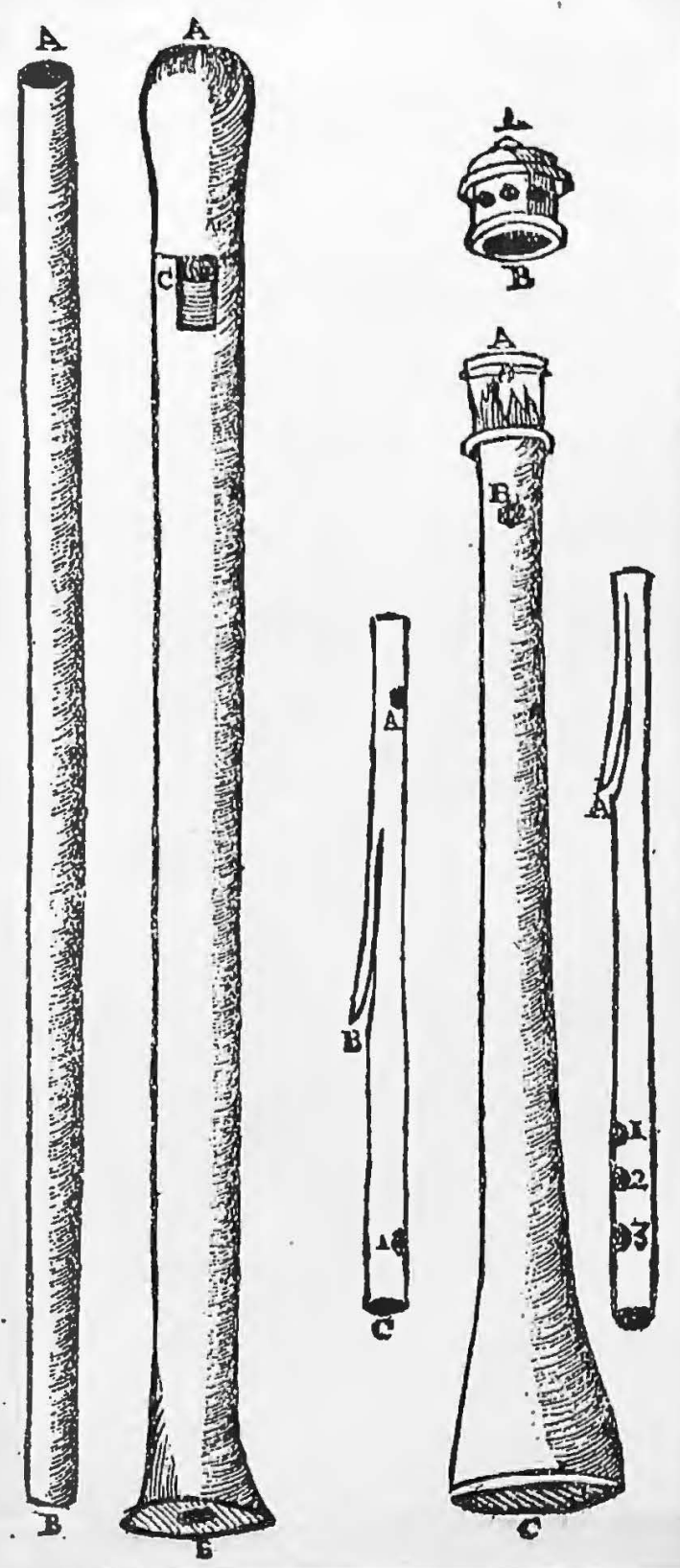

Chalumeau instruments illustrated in Marin Mersenne, Harmonie Universelle (Paris: S. Cramoisy, 1636): The Books on Instruments, trans. by Roger E. Chapman (The Hague: Martinus Nijhoff, 1957), 299. 
different pitches through the means of these three holes". 30 The last tyne of chalumeau in the plate is a kind of wind-capped instrument, whose reed is a thin piece of skin wrapped around the inside of the capsule. It was set into vibration by blowing into the only tone hole near the top of the instrument.

Mersenne mentions at a later point in the fifth book of wind instruments, Proposition XXVI, the various parts and reeds of the "bagpipe of the country people", the chalemie or cornemuse. He clearly illustrates two single-reeds and one double-reed next to the tubes that were inserted in the bag of the chalemie (plate six). The first single-reed was made from straw or wheat and is similar to the third chalumeau of the fourth proposition. It was used in the great bourdon or drone pipe. The second single-reed was made from a single tube in the same manner as the first reed, and was used in the little bourdon or drone. The double-reed, made from a bit of cane, was used in a pipe called the chanter or chalumeau. Mersenne also notes that the chalumeau of this type of bagpipe is played in two ways. First, by using it as part of the bagpipe, second, by pulling it out of the skin to play as a small double-reed instrument. 31

Another contemporary definition of the chalumeau that is practically identical to Mersenne's is found in Trichet's "Traité des instruments de musique" (c. 1640).

30 Miersenne, 298. $31_{\text {Mersenne, } 354-357 .}$ 
PLATE 6

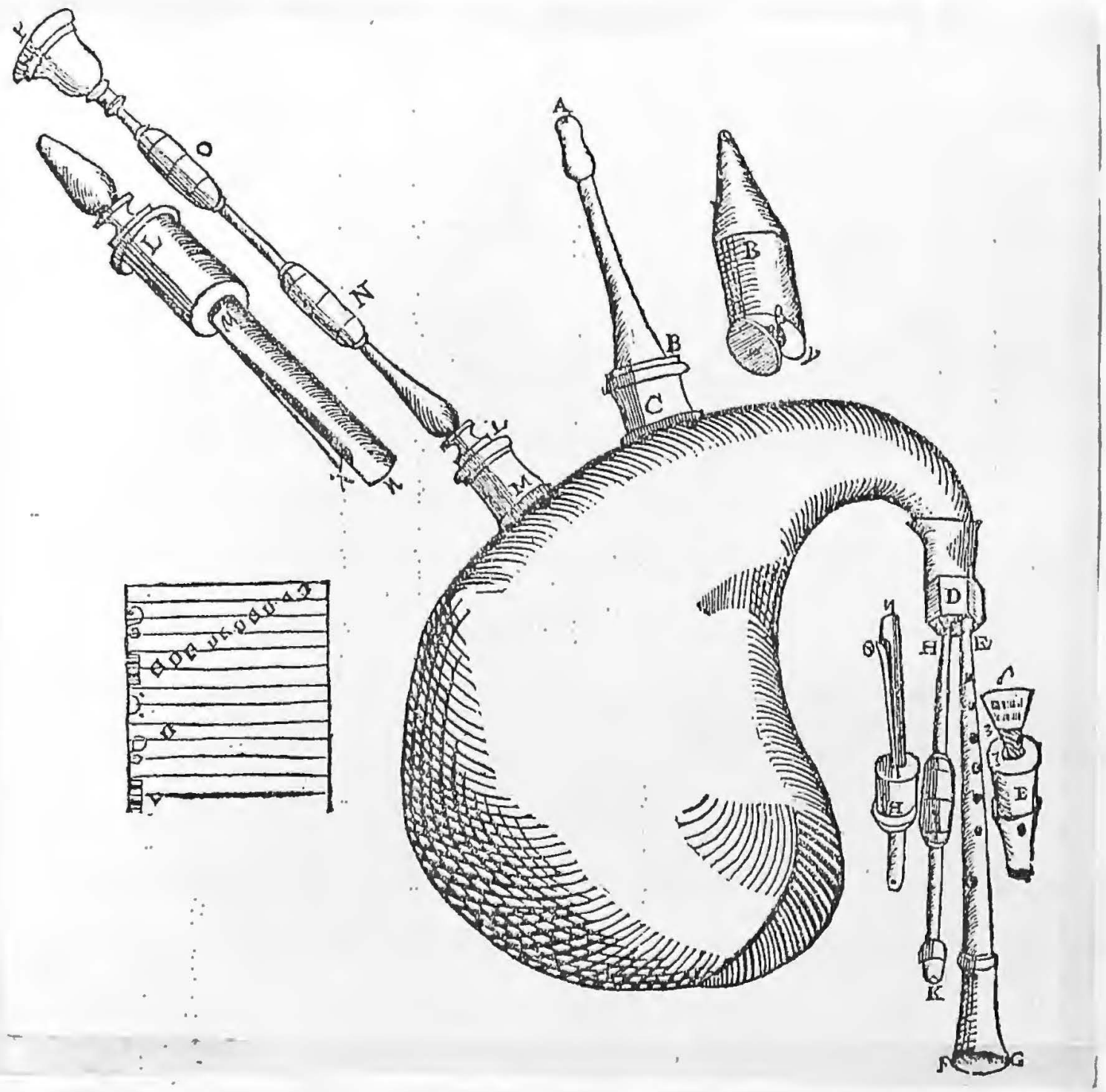

A Chalemie or Cornemuse from Marin Mersenne, Harmonie Universelle (Paris: S. Cramoisy, 1636): The Books on Instruments, trans. by Roger E. Chapman (The Hague: Martinus Nijhoff, 1957), 355. 
The chalumeau is (I) a rustic pipe made from a wheat stalk with a cut in its upper surface, half a foot long, such as are still played by children and young shephards; it is also (2) the chanter of a cornemuse played as a separate instrument. 32

A contemporary illustration of an instrument that seems to be similar to Trichet's first type of chalumeau is found in the oil painting, "Réunion de paysans" by Louis Le Nain (1593-1648).33 Here a peasant boy is playing a small cane pipe, that has an unidentifiable number of tone holes. Unfortunately, the mouthpiece cannot be clearly seen, so it is debatable whether this instrument is a chalumeau or a simple flute.

It is evident from these sources, that in the sixteenth and seventeenth centuries, the chalumeau was used as a simple folk instrument or as a part of the bagpipe. The folk instruments were of the simple idioglot reed type, and the chalumeau or chanter of the bagpipe contained a double-reed. The word chalumeau continued to have both these meanings through the seventeenth and into the eighteenth century. Borjon's chalumeau or chanter is

32 Marcuse, 719, cf. Pierre Trichet, Traité des instruments de musique (vers 1640), with an intro. and notes by Franģois Lesure (Neuilly-sur-Seine: Société de musique d'autrefois, 1957), $92-94$.

33 See, Grand Larousse encyclopédique, s.v. "Classique: art classique. XVII siècle," plate 3; The World Book Encyclopedia, s.v. "Painting," by Thomas Munro, 45. 
a double-reed instrument in his Traité de la Musette (1672), 34 as is Hotteterre's in his Méthode rour la Nusette (1737), 35 and de Garsault's in his Notionaire, ou mémorial raisonné (1761).36 De Crousaz described the chalumeau as a tuyau de bled in his Traité de beau (1715). 37

\section{The Mock trumpet}

By the last decade of the seventeenth century a single-reed chalumeau became popular in England under the name of the mock trumpet. 38 John Walsh's "Catalogue of English and Italian Musick for Flutes" (c. 172l) advertised four "Books for Learners on ye Nock Trumpet". 39 From newspaper advertisements, Smith was able

${ }^{34}$ Rendall, 64, [Charles-Émanuel Borjon], Traité de la Musette, avec une nouvelle méthode (Lyon: Chez Jean Girin, \& Barthelemy Riviere, 1672).

35 Encyclopaedia Britannica, 439, [Jacques] Hotteterre, Méthode pour la Musette (Paris: J.B. Christophe Ballard, 1737).

36 François Alexandre Pierre de Garsault, Notionaire, ou mémorial raisonné (Faris: Guillaume Desprez, 1761), 648-649.

37 Jean Pierre de Crousaz, Traité de Beau (Amsterdam: François L'Honoré, 1715), 239.

${ }^{38}$ See, Thurston Dart, "The Mock Trumpet," GSJ 6 (JuIy, 1953) : 35-40.

${ }^{39}$ See, William C. Smith, A Bibliography of the Musical Works Published by John Walsh During the Years 1695-1720 (London: Bibliographical Society, 1948), plate 28. 
to include the first three books in his talsh bibliography of 1695 to 1720. The title pages of all four books are as follows:

A Collection of Ayers fitted for the new instrument call'd the Mock Trumpet, \& also first and Second Trebles for two Trumpets: Graven price Is (Post Boy, September 13-15, $1(98))^{40}$

A Second Book for the new instrument called, The Mock Trumpet; containing variety of Trumpet-tunes, Ayrs, Marches, Minuets, made purposely for that Instrument: with Instructions for Learners. Also several first and second Trebles for two Trumpets. Engraven. Price Is (Flying Post, May 4, 1699). 41

The 3d Book of the Mock Trumpet. Containing variety of new Trumpet Tunes, Airs and Minuets fitted to that Instrument, and very proper for the Brazen Trumpet, as also for Learners on the Violin, Flute or Hoboy, being both easy and pleasant. Likewise lst and $2 \mathrm{~d}$ Trebles for 2 Trumpets, with directions for Learners, price Is (Fost Man, October 23-26, 1703). 42

The Fourth Compleat Book for the Mock Trumpet Containing Plain and Easy Directions to Sound y ${ }^{e}$ lock Trumpet Together with Variety of new Trumpet Tunes Aires Marches \& Minuets fitted to that Instrument, and Very Froper for $y^{e}$ Brazen Trumpet, also severall First and Second Trebles for two Trumpets the whole Fairly Engraven. Price 6d. Note $y^{e}$

${ }^{40}$ Smith, 6 .

${ }^{41}$ Michael Tilmouth, "A Calendar of References to Music in Newspapers published in London and the Frovinces (1660-1719)," R.M.A. Research Chronicle, no. I (1961, reprint, 1968): 28. 42 Smith, 41. 
first Second and Third Books may be had where these are Sold. London Printed for $I$. Valsh at $y^{e}$ Harp in Katherine Street. I. Hare at $y^{e}$ Viol \& Flute in Cornhill. and P. Randall at $y^{e}$ Violin and Lute with out Temple Barr in the Strand (c. January-February 1707).

From the title pages of the first two mock trumpet books, we know that this instrument was considered a new arrival in England during 1698 to 1699. The fourth book is the only one known to be extant, and is located in the Euing Collection of the Iibrary of the University of Glasgow. It does not appear in Smith's Walsh bibliography, but can be dated by the imprint of the pubIisher. 43 Dart's identification of the mock trumpet as a singlereed chalumeau is based on the contents of this tutor.

The gamut or scale of this instrument is given on the second page as $g^{\prime}$ to g''. Seven tone holes are indicated in this fingering chart (plate seven). The next page of directions for playing states that the thumb hole was on the underside of the instrument, beneath the hole for the forefinger of the left hand. After explaining which holes are to be covered by which fingers, the anonymous author says: "put the Trumpet in your Mouth, as far as the Gilded Leather, and blow pretty strong". 44 The remaining directions deal with how to play the two ornaments used in the music of the book, the "close" and "open Shake". Brief remarks on the rudiments of music make up the fourth page of the tutor. This is

${ }^{43}$ See, Smith, xxvi, Dart, 37.

${ }^{44}$ The Fourth Compleat Book for the Mock Trumpet, [iii]. 


\section{J PL:TE ?}

fingering chart for the mock trumpet from The Fourth Compleat Book for the Mock Trumpet (London: J. Nalsh, J. Hare, and P. Randall, c. 7 707), [iii].

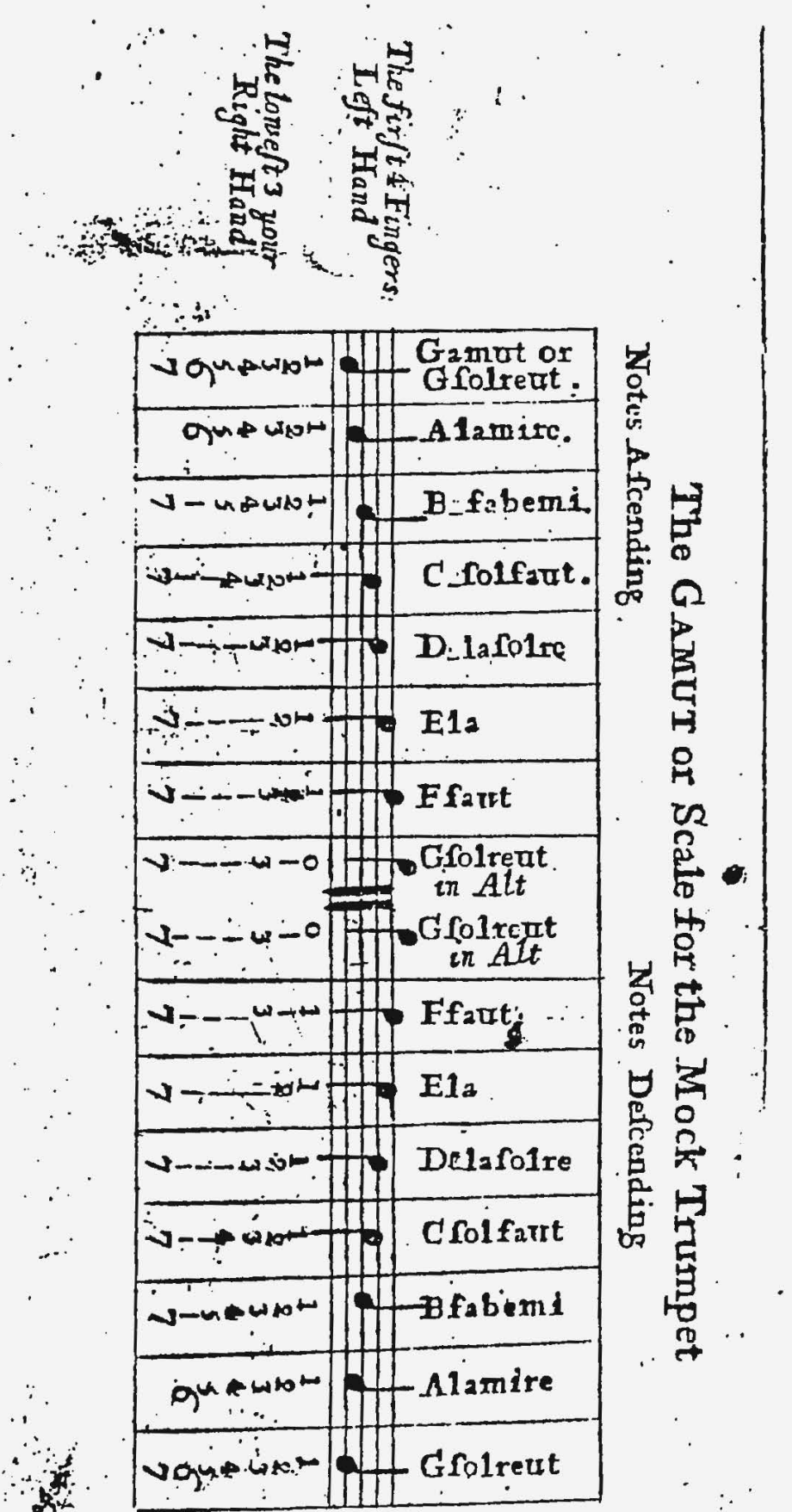


followed by eighteen pages of music, paginated 1 to 18 .

The first three pages are to played by one mock trumpet, the remining pages of music are for "First and Second Trebles" together. All of the pieces are in $C$ major and use the entire garnut of $g^{\prime}$ to $g^{\prime \prime}$ and even to $a^{\prime \prime}$ in four pieces. This note cannot be played on the mock trumpet since it is above the given range, however it would have been available on the brazen or natural trumpet, as is stated in the title page. In fact, the tunes are largely based on notes of the harmonic series, exceptions such as $a^{\prime}$ and $b^{\prime}$ occuring once in the duets and three times in the solo section. Because of the similarity of fingering between the alto recorder and mock trumpet, Dart suggested that this music may have also been used in Walsh's Fourth Book of the Compleat Flute Master (Post Nan, February 15-18, 1707), which is not extant. 45 Baines states that Bonanni's description of a keyless chalumeau is identical to the mock trumpet. 46 This description occurs in the article, number 23 , on the oboe.

Prima di terminare questa narrativa, non è da lasciarsi l'accennare, che trà gl'Istromenti, li quali si suonano col fiato uno ve n'è, (se bene non molto adoperato) il quali volgarmente se chiama Scialumò, suole esser questo fatto di canna a modo di Zampogna, e lungo come il Flauto, e hà buchi

45 Dart, 37

${ }^{46}$ Baines, 296 . 
sette, cioè sei di sopra, ed uno di sotto. 47

Before ending this narrative, I have not allowed myself to point out that among the instruments, which are sounded with wind there is one (at best not much employed) which is commonly called scialumò [chalumeau]. Usually this is made of cane in the manner of a zampogna, as long as the flute, it has seven holes, that is, six above and one below.

Bonanni's zampogna was a wheat stalk chalumeau similar to Mersenne's tuyau de blé. 48 The instrument that was exhibited at the Royal Military Exhibition in London, as a chalumeau, closely resembles Bonanni's scialumò. Baines mentions a description of this instrument found in Day's catalop of the Exhibition as follows: of cane, $8 \%$ inches long with 15 millimeters bore, covered with red leather, and sounding from $g^{\prime}$ to $\mathrm{g}^{\prime \prime}$ in fundamentals. 49 This description of its range and use of leather matches the mock trumpet exactly.

Further evidence of the mock trumpet's use in England is

47 Filippo Bonanni, Gabinetto Armonico pieno d'Istromenti sonori (Roma: Giorgio Placho, 1722), 68. All translations not otherwise attributed are by the present writer.

${ }^{48} \mathrm{Cf}$. Filippo Bonanni, Antique Musical Instruments and Their Players, 152 Plates from Bonanni's 18th Century "Gabinetto Armonico," with a new intro. and captions by Frank Ll. Harrison and Joan Rimmer (New York: Dover, 1964), plate 27.

$$
{ }^{49} \text { See, Baines, } 296 .
$$


found in an advertisement by a London music shop in The Diverting Fost of 25 November 1704.

Tilder's Mock Trumpets, which have been so well approv'd of by the greatest Musick Masters in England, and allow'd to imitate the Real Trumpet almost to Ferfection, are Sold at most "usik-Shops in London . . 50

As late as 27 October 1718, The St. Ives Fost Boy or the Loyal Packet advertised mock trumpets for sale in the bookshops of "George Barton, of Huntingdon" located in Feterborough, St. Ives and St. Neots. 51 Baines postulated that "the mock trumpet was sold at first c. 1695 as a musical toy, but redesigned in the eighteenth century using a mouth piece with tied-on reed as in the clarinet and also probably due to Denner". 52

\section{The eighteenth-century chalurneau}

At the same time that the mock trumpet was initially used in England, a single-reed chalumeau was initially used in Germany. Mattheson's autobiographical sketch of Telemann in his Grundlage einer Ehren-Pforte (1740) reveals that during his stay at Hildesheim, Telemann became acquainted "mit dem Hoboe, der

$$
\begin{aligned}
& 50 \text { Tilmouth, } 57 . \\
& 51_{\text {Tilmouth, } 103 .} \\
& 52 \text { Anthony Baines, European and American Nusical Instruments, }
\end{aligned}
$$
(New York: The Viking. Press, 1956), 112. 
Traverse, dem Schalumo, der Gambe" as well as other instruments. 53 Becker states that Telemann stayed in Hildesheim from 1697 to 1701 and that here, he made contact with French musicians from the neighboring court of Brunswick. 54 Reinhard Keiser's subsequent use of the chalumeru in Hamburg probably indicates his exposure to it, when he was the Kapellmeister at Brunswick before 16.95 . The French chalumeeu players at Brunswick are another indication that this instrument originally developed during the seventeenth century, in Parisian workshops. 55 Here, the Freat amount of activity with wind instruments changed and developed the recorder, flute, oboe and bassoon. 56 In fact, it has only recently been advocated that the chalumeau represents a development of the recorder, rather than of a folk instrument. 57

Ever since the publication of Johann Gabriel Doppelmayr's book, Historische Nachricht von den Nurnbergischen Mathematicis

53 See, Johann Mattheson, Grundlage einer Ehren-Pforte (Hamburg, 1740, reprint ed., ed. by Max Schneider, Kassel: Burenreiter, 1969), 357.

54 Heinz Becker, "Das Chalumeau bei Telemann," Konferenzbericht der 3. Magdeburger Telemann-Festtage, Magdeburg: Deutsche Kulturband (1969): 69.

55 See, Becker, 69.

${ }^{56}$ Baines, Woodwind Instruments and Their History, 276.

57 See, Colin Lawson, "The Early Chalumeau Duets," GSJ 27 (April 1974): 125 . 
und Kunstlern in 1730, Johann Christoph Denner (1655-1707) has reen credited with the improvement of the chalumeau, as well as the invention of the clarinet. Denner, the son of a Nurember hunting-horn turner (J̈gerhorndreher), ${ }^{58}$ Heinrich Denner, established a well-known business by building excellent and generally popular recorders, oboes, bassoons, pommers, racketts, chalumeaux and clarinets. He trained his two sons, Jacob (1681-1735) and Johann David (1691-1764) in the art of instrument building, but only some of Jacob's instruments have survived. Today, at least sixty-eight wind instruments made by J.C. and Jacob Denner are extant in museums and private collections. 59

The important and significant passage concerning the chalumeau and clarinet, in Doppelmayr's biographical account of J.C. Denner, is cited here:

Zuletzt triebe ihn sein Kunst-Belieben annoch dahin an, wie er noch ein mehrers durch seine Erfindung und Verbesserung bey bemeldten Instrumenten dargeben mbgte, dieses gute Vorhaben erreichte auch wurcklich einen erwunschten Effect, indeme er $z u$ Anfang dieses lauffenden Seculi, eine neue Arth von Pfeiffen-Wercken, die so genannte Clarinette, zu der Music-Liebenden grossen Vergnugen, ausfande . . .

${ }^{58}$ Oskar Kroll, The Clarinet, rev. and with a repertory by Diethard Riehm; trans. by Hilda Morris; trans. ed. by Anthony Baines (New York: Taplinger, 1968), 125.

${ }^{59}$ Phillip T. Young, "Woodwind Instruments by the Denners of Nurnberg," GSJ 20 (March 1967): 9. 
endlich auch die Chalumeaux verbesserter darstellte. ${ }^{60}$

Finally his artistic passion compelled him to seek ways of improving his invention of the aforesaid instrument, and this praiseworthy intention had the desired effect. At the beginning of the current century, he invented a new kind of pipe-work, the so-called clarinet, to the great delight of all music lovers, and at length presented an improved chalumeau. 61

Denner's improved chalumeau consisted of a cylindrical tube made of boxwood, having a replaceable can reed tied on to a beak-like mouthpiece. It also had two opposing keys above the thumb hole and closely resembled the recorder.

The first comprehensive definition of the word chalumeau, is initially found in Walther's Musikalisches Lexicon (1732). Walther gives four types that were in use, helping to clear up the uncertainty of meaning this word had acquired.

Chalumeau, pl Chalumeaux (gall.) Fistula pastoritia [lat.] eine Schallmen, Schमffer-Pfeiffe; weil sie mehrentheils aus Rohr [so calamus heisset] gemacht ist. Nebst dieser Bedeutung wird auch die an einem Dudel-Sacke befindliche Pffeiffe; ferner ein kleines Blass-Instrument, so sieben Lbcher hat, und vom f'biss. ins a' gehet; also genennet Ferner ein kleines aus Buchsbaum verfertigtes

${ }^{60}$ Johann Gabriel Doppelmayr, Historische Nachricht von den Nurnbergischen Mathematicis und Kunstlern (Nurnberg: P.C. Monath, 1730), 305.

$6 I_{\mathrm{KrOII}}, 13-14$. 
Blas-Instrument, so sieben Lbcher oben beym Ansatze, zwo messingene Klappen, auch bey der untern noch ein a partes Loch hat, und vom f' biss ins a' und b'', auch wohl biss ins $h$ ' und $c$ ' gehet. 62

Chalumeau, plural, Chalumeaux (french), Fistula pastoritia (latin). A shawm, shepherd's pipe made from some parts of cane called calamus. Besides this meaning, it is also found as the chanter in a bagpipe. Furthermore, it is a small woodwind instrument that has seven holes and a range from f'to a''. Also the name for a little wind instrument made from boxwood that has seven holes, two brass keys up near the mouthpiece, and an additional à partes hole near the bottom. It has a range of from $f^{\prime}$ to a'' and b-flat'', possibly also to b'' and c'''63

Not surprisingly, the first two definitions correspond to Trichet's definition a century earlier, as well as to Mersenne's descriptions. The last two instruments correspond to Bonnani's scialumo and the chalumeau that Doppelmayr stated was improved by J.C. Denner. The à partes or double hole was provided at the bottom of the latter instrument, to enable the performer to play with the right or left hand uppermost. The hole not being used was probably filled in, as suggested by Kroll. 64

62 Johann Gottfried Walther, Musikalisches Lexicon, oder musikalische Bibliothek (Leipzig: Wolffgang Deer, 1732, reprint ed., ed. by Richard Schaal, Kassel: Burenreiter, 1953), 153.

${ }^{63} \mathrm{Cf}$. Angela Maria Owen, "The Chalumeau and Its Music," American Recorder 5, no. 1 (1967): 7 .

${ }^{64}$ Oskar Kroll, "Das Chalumeau," ZfM 15, no. 8 (May 1933): 374. 
lalther's entire definition is repeated verbatim in Majer's Museum Nusicum, ${ }^{65}$ of the same year, as well as in his Neu-erbffneter theoretisch und praktischer Music-Saal (1741).66 In addition to this description, Majer provides, in both books, the following important description of the eighteenth-century, sinfle-reed chalumeau:

Man hat sonst Discant, Alt-oder Quart-Chalumeaux, wie auch Tenor-und Bass-Chalumeaux, theils mit dem Franzbsischen/theils mit Teutschem Ton/ und sind absonderlich ratione des schwehren Ansatzes/ sehr hart zu blasen/ die Application darauf correspondiret meistens mit denen Flbthen; Allein deren Ambitus erstrecket sich nicht viel uber eine octav. Wird derhalben vor unnbthig erachtet/ weitluufiger hievon zu melden/ zumalen/ wan man eine Flbthen blasen kan/ wird man auch hier praestanda praestiren kbnnen. 67

One has besides discant and alto- or quart-chalumeaux, tenor and bass-chalumeaux parts, some with French and some with German pitch. They are, by particular reason of the strong mouthpiece, very hard to blow. The fingerings of these correspond most closely with the flute, but their range does not extend much beyond an octave. For that rea-

65 J.F.B.C. Majer, Museum Musicum Theoretico Practicum das ist Neu-erbffneter Theoretisch-und Practischer Music-Saal (1732), facsimile ed., ed. by Heinz Becker (Kassel und Basel: Burenreiter, $1954), 32$.

66 J.F.B.C. Majer, Neu-erbffneter theoretisch und praktischer Music-Saal (Nurnberg: Johann Jacob Gremer, 1741), 43. 67 Majer, Museum Musicum, 32. 
son, it is deemed unnecessary to report at further length on this matter, especially since if one can play the flute one can also perform easily. 68

From this account we discover the chalumeau in the eighteenth century was built in a consort of four sizes, undoubtedly to compensate for their range of a twelfth at most. Van der Meer has deduced the range of each member of this consort, after examining music written for these instruments, as follows: Soprano: f' to b-flat'', $b^{\prime \prime}$ or $c^{\prime \prime \prime}$; Alto or Quart: $c^{\prime}$ to f''; Tenor: $f$ to b-flat'; and Bass: c to f'.69 The tenor and bass were usually notated in the bass clef an octave lower than sounding.

Parts for the chalumeau initially appeared in 1704 in $M . A$. Ziani's opera, Caio Pompilio at Vienna. Here it was designated in the scores of various operas, mainly in the first two decades of the century. Among the composers who scored for it are: G.B. Bononcini, A.M. Bononcini, Ariosti, Fux (ten operas), Bonno, Dittersdorf and Gluck. Hasse, Heinichen and Zelenka helped make it popular in Dresden. Chalumeau instruments originating from

${ }^{68}$ Cf. Heinz Becker, "Zur Geschichte der Klarinette im 18. Jahrhundert," Mf 8 (1955): 277, English trans., by Don Halloran (August 1971), 11 (typewritten).

${ }^{69}$ John Henry Van der Meer, "The Chalumeau Problem," GSJ 15 (March 1962): 90. The Moeck Verlag of Celle, West Germany used this pitch scheme in their reproductions of the consort of chalumeau. They are based upon the chalumeaux extant in the Musikhistoriska Museet of Stockholm. 
there were sent in 1724 to the chapel of the court of Zerbst, where Fasch also wrote for them. 70 Telemann and J.B. Kbnig in Frankfurt, as well as Graupner in Darmstadt contributed greatly to the repertoire of chalumeau music. A listing of the fortyfive instrumental works and the thirty-seven operas, cantatas and oratorios that prescribe the chalumeau, is given as the first appendix.71

Besides the use of the chalumeau in these German cities it was shown to have arrived at an early date in the Netherlands, by the 1706 catalog of the Amsterdam publisher, Estienne Roger. This catalog, appended to Felibien's Recueil historique, advertised "Fanfares et autres airs de chalumeau à 2 dessus" by J.P. Dreux, as well as, chalumeaux for sale at three florins apiece. 72 Two volumes of these Fanfares are extant in Wolfenbuttel, their titles read:

FAIFARES/ Pour les Chalumeaux \& Trompettes/ Propres aussi à jouer sur les Flutes, Violons \& Haubois/ Composées Par/ JAOUES PHILIPFE DREUX/ Livre Prernier (Second)/ A AMSTERDAM/ Chez Pierre Nortier sur le Vyngendam/ qui vend les Livres Nouveaux en Musique.

70 Heinz Becker, "Das Chalumeau im 18. Jahrhundert," Speculum Musicae Artis. Festgabe fur Heinrich Husmann zum 60. Geburtstag, Munchen: Wilhelm Fink (1970): 35.

${ }^{71}$ See, Appendix A: A List of Musical Works Using the Chalumeau.

$$
72_{\text {Rendall, } 64 .}
$$


The music of these duets is confined to $g^{\prime}, c^{\prime \prime}$ to $g^{\prime \prime}$ and therefore suitable for a keyless chalumen. Similar to the contents of The Fourth Compleat Book for the Mock Trumpet, these duets are further examples of an early association of the chalumeau and trumpet idiom. 73

In later instrumental works, the "improved" chalumeau is occasionally treated in a virtuosic manner, e.r., Handel's Riccardo Frimo (1727), J.I. Bach's Cantata (1728), Vivaldi's Juditha Triumphans, ${ }^{74}$ and Bonno's Eleazare (1738). Van der Meer has pointed out that some Viennese court composers utilized a trio consisting of two soprano chalumeaux and a tenor, the latter always designated as a basson. Thus forming a counterpart to the well-known double reed trio of two oboes and bassoon. 75 The first known appearance of the chalumeau on the concert stage occurred at a performance of a concerto by an unknown performer at the Concert Spirituel in Paris. The Mercure de France (February 2l, 1728) reported:

On joua ensuite un Concerto de chalumeau, avec les accompagnemens de la Simphonie qui forment les choeurs. Cet instrument qui est fort en usage en Allemagne, imite le Haut-Bois et la Flute à Bec. Le tout ensemble parut assez

${ }^{73}$ Laws on, 126

74 Owen, 9-10.

75 Van der Meer, 90-91, Van der Meer, "Some More Denner Guesses," GSJ 23 (August 1970): 119. 
singulier et fin plaisir...76

They played a concerto for chalumeau with the accompaniment of the symphony, who formed the choruses. This instrument, which is greatly used in Germany, imitates the oboe and the recorder. The whole thing had quite a singular effect and gave pleasure...77

This report provides additional proof that the "improved" chaIumeau originated in Germany. A description of it appears in Gabinetto Armonico (1722) under the article entitled Oboè, as the calandrone: 78

Un altra specie di Scialumò dicesi dalli Suonatori Calandrone, il quale hà li buchi, come li Flauti, e nel principio dell' imboccatura hà due molle, le quali premute, danno il fiato per due buchi op osti in diametro, dove si pone la bocca e inferita un Zampogna, rende questo un suono rauco, e poco grato, e si suona colle medesime regole delli Flauti. 79

Another species of scialumò, according to performers, is the calandrone, which has holes like the flutes. Near

${ }^{76}$ Pamela Weston, Clarinet Virtuosi of the Past (London: Robert Hale, 1971), 20.

${ }^{77}$ Cf. Jacques-Gabriel Prod'Homme, "Austro-German Musicians in France in the Eighteenth Century," The Musical Quarterly 15, no. $2(1929): 178$.

${ }^{78}$ See, Van der Meer, "The Chalumeau Problem," 89-90.

${ }^{79}$ Bonnani, Gabinetto Armonico, 68. 
the beginning of the mouthpiece are two keys that cover two diametrically opposite holes. The lips are pressed as in the zampogne, and it renders a raucous sound that is not pleasant. It is played in the same manner as the flute.

The unpleasant sound of this instrument is also noted by Walther, in his manuscript, "Fraecepta der musicalische Composition" (1708). "Chalemau (gall) ist ein kurtz blasend Instrument, giebt einem Klang von sich, als wenn ein Mensch durch die Zahne singet". 80 Chalemau (french) is a short wind instrument giving a sound similar to when a person sings through his teeth. In 1713, wattheson made a contemptuous remark about the sound of this instrument in his neu-erbffnete Orchestre:

Den so genandten Chalumeaux mag vergbnnet seyn/ dass sie sich ihrer etwas heulenden Symphonie des Abends etwann im Junio oder Julio, niemals aber im Januario auff dem Wasser zum stunchen/ und zwar weitem horen lassen. 81

The so-called chalumeaux may be allowed to voice their somewhat howling symphony of an evening, perhaps in June or July and from a distance, but never in January at a serenade

80 Johann Gottfried Walther, Praecepta der musicalischen Composition (1708), facsimile ed., ed. by Peter Benary (Leipzig: Breitkopf \& Hurtel, 1955), 43.

${ }^{81}$ Johann Mattheson, Das neu-erbffnete Orchestre (Hamburg, 1713), 272, as quoted by Becker, "Das Chalumeau im 18. Jahrhundert," 23. 
on the water. ${ }^{82}$

Mattheson is probably indicating the mixed use of transposing and different sizes of chalumeaux. ${ }^{83}$ The sound of these instruments must also have been quite loud to be heard "from a distance". On the other hand, it seems unlikely that an unpleasant instrument with a very strong tone would have been used in combination with particularly gentle instruments, e.g., Graupner's trio for tenor chalumeau, viola d'amour and basso continuo; and buverture for soprano and tenor chalumeaux, two violetta and basso continuo. Probably these chalumeaux instruments differed a great deal in regard to dimensions and mouthpieces. Some may also have sounded better then others. 84

Inother disparaging remark was made in 1738 by Eisel when he called the chalumeau "Verrostet" (rusted, antiquated) in his Musicus Autodidaktos. ${ }^{85}$ By 1753, according to the article in the

$82_{\text {Kroll, }}$ The Clarinet, 15.

${ }^{83}$ See, 稇GG (1958), s.v. "Klarinette: C. Die europlische Klarinette," by Heinz Becker, 7: col. 1007; trans. by Dyke Kiel, The Clarinet 2, no. 3 (May 1975): 6 .

${ }^{84} \mathrm{Kroll}$, The Clarinet, 15-16.

${ }^{85}$ [Johann Philipp Eise1], Musicus Autodidaktos oder sich selbst informirende Musicus (Erfurt: Johann Michael Funcken, 1732), as mentioned by Becker, "Das Chalumeau im 18. Jahrhundert," 23. 
Encyclopédie, "Il n'est plus en usage en France". ${ }^{86}$ Its earlier popularity had turned to disdain:

Ce chalumeau a le son desarréable \& sauvare: j'entends, quand il est jollé par un musicien ordinaire; car il n'y a aucun instrument qui ne puisse plaire sous les doigts d'un homme supérieur... ${ }^{87}$

This chalumeau has an unpleasant and uncivilized sound, that is, it is usually played by an ordinary musician because there is no instrument that is not able to please under the fingers of a superior man ...

One of the two existing illustrations of a chalumeau appears in the Lutherie plates, volume five of the Planches (1767). ${ }^{88}$ It is reproduced here (plate eisht) and is described as:

-. un instrument à vent \& à anche, comme le hautbois. Il est composé de deux parties; de la tête, dans laquelle est montée l'anch semblable à celle des orgues, excepté que la languette est de roseau, \&: que le corps est de bouis; du corps de l'instrument, où sont les trous au nombre de neuf. 39

${ }^{86}$ Encyclopédie, ou Dictionnaire raisonné des sciences, des arts et des metiers par un societe de gens de lettres (Paris: Briasson, David, Le Breton, 1753), vol. 3, s.v. "chalumeau".

87 Encyclopédie, vol. 3, 5.v. "chalumeau".

88 Encyclopédie.. Recueil de Planches (Taris: Briasson, David, Le Breton, 1767), vol. 5, plate 8 . ${ }^{89}$ Encyclopédie, vol. 3, s.v. "chalumeau". 
PLATE 8
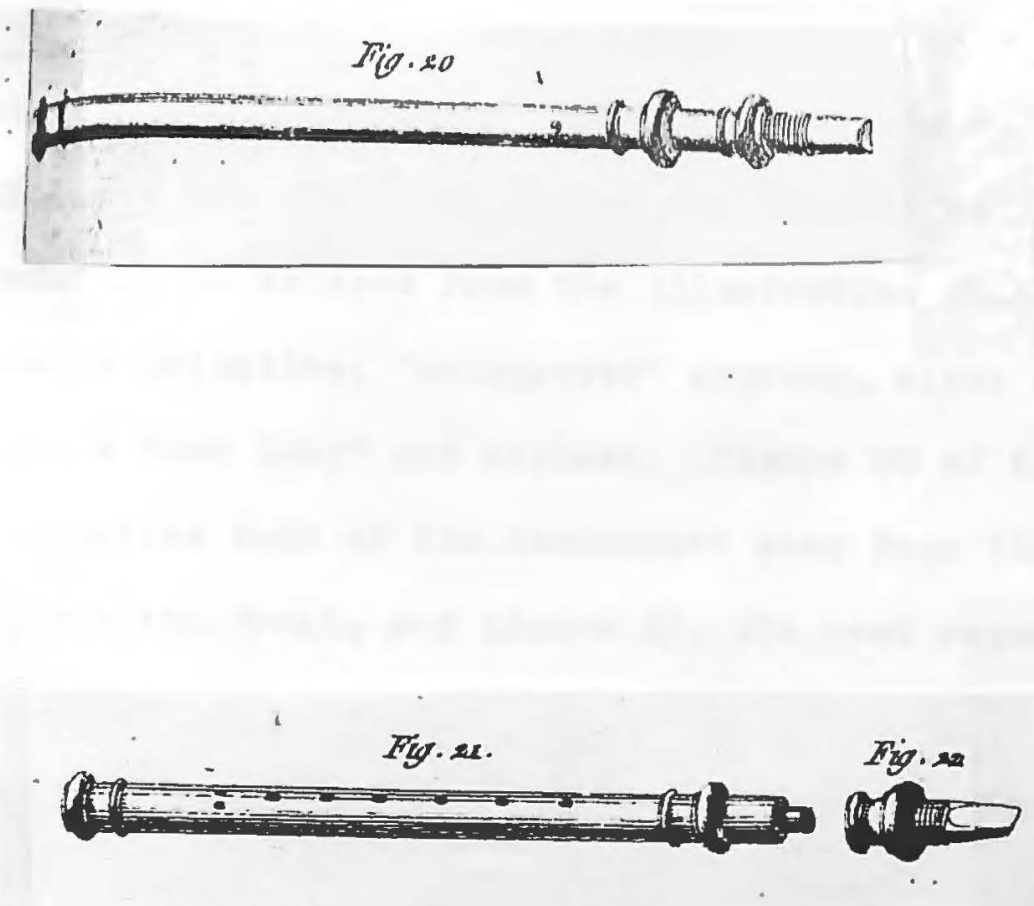

A keyless soprano chalumeau from the Encyclopédie.. Recueil de Planches (Paris: Briasson, David, Le Breton, 1767), vol. 5, plate 8. 
- - a wind instrument with a reed like the oboe. It is composed of two parts; the head, on which is attached a reed resembling that of the organ, except that it is of cane, and the body made of wood. The body of the instrument has nine holes.

The first hole was for the thumb opposite the eicht holes on the front side of the instrument. The last hole can be seen to be actually two holes divided $\grave{a}$ partes, as walther had originally described. It is evident from the illustration that this chalumeau was a primitive, "unimproved" soprano, since it was also "less than a foot long" and keyless. Figure 20 of the plate shows the entire body of the instrument seen from the back, figure 21 , from the front, and figure 22 , the reed separated from the instrument.

A soprano chalumeau identical to the above description is found being played by a cherub in the frontispiece to Theofil Wuffat's Componimenti Musicale per il Cembalo (c. 1736).90 La Borde in his Essai de la Musique $(1790)^{91}$ repeated the information from the Encyclopédie, in describing the chalumeau, adding that it was also called the zampogne. The second illustration of this instrument appeared as late as 1795 in J.V. Reynann's Muzijkaal Kunst-woordenboek, as a very primitive soprano instrument with

90 DTÓ, vol. 7, Jahrgang 3, no. 3, ed. by Guido Adler, see, Encyclopaedia Britannica, 440 .

91 [Jean-Benjamin de La Borde], Essai sur la musique ancienne et moderne, 4 vols. (Paris: Ph. D. Pierres, 1780), 1: 248-249. 
one key and without any hole for the little finger. ${ }^{92}$ A few chalumeau instruments are still extant in various museums. Among them are: Nahillon's reconstruction of a soprano (Brussels Conservatoire), 93 an anonymous soprano (Munich, Bayerisches Niationalmuseum, no. 19), 94 Stuenwal's soprano (Nuremburg, Germanisches Nationalmuseum), 95 Liebav's soprano and alto (Stockholm, Musikhistoriska Museet, nos. 139, 143), Klenig's alto's (Stockholm, nos. 141, 142), and Muller's soprano (Stockholm, no. 140).96

\section{The two-key clarinet}

The earliest provable date for the appearance of the term, "clarinet" was shown by Hickel to be in 1710.97 In this year,

92 Joos Verschuere Reynvaan, Wuzijkaal Kunst-woordenboek (Amsterdam: Wouter Brave, 1795), 149, see, the illustration in fdam Carse, Msical ilind Instruments (London: Macmillan and Co., 1939), 149 .

93 See, Kroll, The Clarinet, plate 2.

94 See, Rendall, plate I, a.

95 See, Baines, European and American Musical Instruments, 112 .

${ }^{96}$ See, Becker, "Das Chalumeau im 18. Jahrhundert," illustrations $1-4$.

97 Ekkehard Nickel, Der Holzblasinstrumentenbau in der Freien Reichsstadt Nurnberg (Munchen: Emil Katzbichler, 1971), 209. 
Jacop Denner (1681-1735), the son of Johann Christoph, received an order for a large number of instruments for the Graf von Gronsfeld (Earl of Gronsfeld) in Nuremberg. In this list, Nuremberg city document 1282, "2 Clarinettes" appear for the first time. This list is quoted here in its original wording:

\section{Specification}

Derer Instrumenta, welche fur Ihro Excellenc Herrn GeneralFeldt-Marchal Grafen von Gronsfeldt verfertiget und veraccordigt worden, als:

4 Hautbois, von Buchsbaum, a fl. 5

$\mathrm{fl} . \mathrm{Kr}$.

1 Taillie

2 Fagott, a fl. 14

4 Flauten, à $\mathrm{fl} .3$

1 Alt-Flauden

2 Bass-Flauden, à $\mathrm{fl} .8$

4 Chalimou, à fl. 3

1 Alt-Chalimou

2 Chalimou-Basson, a fl. 14 $20 .--$

2 Clarinettes $7 \cdot--$ 3.8.-$12 .--$ $5 .--$ $16 .--$ $12 .--$ $5 .--$ 28.-$15 .--$

Die Kisten, worrinen diese Instr. gepackt

4 Violin, $\mathrm{fl}$. 7 28.--

1 Viola

1 Bass

Die Kisten, worrin die Violin. gepackt

unterthaniger Diener Jacob Denner. 98

98 Nickel, 251-252. 
The chalumeau are soprano, alto and bass instruments. Because the price is much lower than the fourteen florins charged for the bass chalumeau, these clarinets were probably small high pitched instruments in $D$ or $E$. It is evident from this list and a similar one ordered from Jacob Denner for Gottweif Abbey, 99 that a distinction was made, at this time, between the "chalimou" and the clarinet.

In the same year a "Clarinett" appeared in the account book of the Eberbach/Rheingau Abbey in Niesbaden. Gottron also reported that six clarinets were brought from Mainz to the Eberbach/ Rheingau Abbey. 100 Subsequently, the church records of the Vereinigtes protestantisches Kirchenvermbgen der Stadt Nurnberg (association of the Protestant church of the city of Nuremberg, 228, no. 3, 70 and no. 5, 78) reveal that four clarinets were supplied by Jacob Denner for Nuremberg's Frauenkirche, between 1711 and 1712, and two more for the Sebaldkirche in 1714. The clarinet, according to Doppelmayr, was invented at the same time as the improvement of the folk chalumeau by J.C. Denner. Becker succinctly summarized this occurence:

\section{${ }^{99}$ See, Horace Fitzpatrick, "Jacob Denner's Woodwinds for} Gottweig Abbey," GSJ 21 (March 1968): 81-87. Nickel refutes Fitzpatrick's assumption that the premier, second and basson chalimou on this list, were a clarinet in $C$, in B-flat and a bass clarinet.

100 Adam Gottron, Mainzer Musikgeschichte von 1500 bis 1800 (Mainz, 1959), 116, as cited by Nickel, 209. 
Historically, the process appears to have been that Denner improved the folk chalumeau, first throurh the mounting: of two diametrically-olacad keys and by exoandine the chalumeau into farilies after the pattern of the Flute à bec. Simultaneously, or perhaps somewhat later, he widened the bore, and made the upper register accessible. This early clarinet-type is characterized by the diametrical layout of tlee keys. 101

Examples of these "early" two-key clarinets are found by J.W. Oberlender (1698-1779) and Jacob Denner (Berlin, Musikinstrumente-kuseum, nos. 2870, 223). 102 Nickel designates J.C. Denner's two-key clarinet (Munich, Bayerischen Nationalmuseum, sign. 136, $\mathrm{Mu} . \mathrm{K} \cdot 20)^{103}$ as a tenor chalumeau, after a comparison of this instrument to Liebav's and Klenig's chalumeaux. 104 The difference between the "early" clarinets and the chalumeau is that the clarinets have a wide bell lacking in the chalumeau, and the keys are closer to the mouthpiece, situated on a much narrower bore then

${ }^{10 I_{M G G}, s . v . ~ " D i e ~ e u r o p d i s c h e ~ K l a r i n e t t e, " ~ c o l . ~ 1007 ; ~ t r a n s . ~}$ by Dyke Kiel, The Clarinet, 6.

$102_{\text {MGG }}$, Ibid., Rendall, 68; see, Kroll, The Clarinet, plates 5,6 .

103 See, Froll, The Clarinet, plate 3; copies of this instrument are found in the Brussels Conservatoire, no. 911, Boston Museum of Fine Arts, and the Crosby Brown collection in New York, no. 1845 .

104 Nickel, 210-211. 
that of the chalumeau. 105 These clarinets can also be played in a higher register by using either of their keys, where the chalumeau is limited to a tenth or twelfth.

The next stage of development was reached when the dorsal key was moved closer to the mouthniece, so that an easier response was achieved through the repositioning of the hole of the thumb key. 106 This resulted in the gain of the note b-flat' produced with both keys, $a^{\prime}$ with either key, but the loss of a b', which had to be obtained by lowering the c'" with a flexible embouchure. 107 Another improvement was the slight reduction in the size of the mouthpiece and the reed. Because a Jakob Denner two-key clarinet (Brussels no. 912) incorporates these changes, he is often credited with these improvements. 108 In any case, they must have taken place before 1722, the date of Bonanni's Gabinetto Armonico. Another instrument appearing under the article on the oboe has been identified with the "improved" twokey clarinet:

Un' Istromento simile all' Oboè nominato Clarone e lungo palmi due e mezzo, termina con bocca di Tromba larga oncie 3. E bucato in sette luoghi nella parte superiore, e

105 Nickel, 211.

$106 \underline{\mathrm{MGG}}, \mathrm{s.v}$. "Die europulische Klarinette," cols. 1007-1008;

trans. by Dyke Kiel, The Clarinet, 6.

107 See, Rendall, plate I, e.

$108_{\text {Rendall, } 68 .}$ 
in uno nella parte opposta inferiore. Oltre a questi buchi ne hà due altri laterali opposti, mà non in diametro, li quali si chiudono, e aprono con due molle calcate con le dita, quando bisogna variare li tuoni, li quali sono piu bassi della voce formata dall' Oboè.

Chi sia stato il primo inventore di tal' Istromento non l'hò trovato riserito da alcuno scrittore, siccome da niuno sù descritto, segno manifesto non esser antico, mà moderno dedotto dalli Flauti, per avere voce piu alta, e vigorosa, ne è si facile e spiogarsi colla penna, come la comprende l'udito, da cui si distingue, e conosce, benchè confusa nelle Sinfonie con la voce di altri Istromenti Musicali. 109

An instrument similar to the oboe is called the clarone. It is two and one half palms long, terminating in a bell like the trumpet three inches in width. It is pierced with seven holes in front and one behind. Other than these holes there are two other holes opposite to each other, but not diametrically. They are closed and opened by two springs pressed by the finger when it is necessary to vary the tones which are much lower than that formed by the oboe. 11.0

I have not found the inventor of this instrument referred to by any author. Since no one has shown a trace of its antiquity, it is modern, originating from flutes. Because it has a high and vigorous sound it is not as easy to explain in writing, as it is when you hear it. It is distinguishable, even though confused with other sounds of musical instruments in symphonies.

${ }^{109}$ Bonanni, Gabinetto Armonico, 67-68. ${ }^{110} \mathrm{Cf}$. Rendall, 68. 
Bonanni emphasizes that the two holes at the top of the clarone are not diametrically opposite as in the improved chalumeau, or his scialumò. He intimates that with the use of these holes this instrument is able to play as high as the oboe, and by closing them, is able to extend its range much lower than that of the oboe. Doppelmayr had not yet written of Nenner, but Bonanni had already deduced the origin of the clarinet, in its resemblance to the recorder and calandrone. Its "high and vigorous sound" was so characteristic of the instrument that Bonanni made a special point of mentioning it.

At the same time in Nuremberg, it is evident that the clarinet became popular with the nobility. The earliest representation of a clarinettist is found in Johann ileigel's loose sheet edition of engravings, Musicalisches Theatrum (before 1726). III Here (plate nine), an elegantly dressed gentlemen is playing the clarinet in what might have been a royal residence. However, this engraving was not taken from an actual observation of a person playing, but was probably copied or adapted from another engraving. 112. In any case, the clarinet was considered highly enough to be used by the nobility as an indoor instrument. The

${ }^{11}$ Johann Christoph Weigle, Musicalisches Theatrum auf zu dieser edlen Kunst gehbrige Instrumenta (Nurnberg: Joh. Christoph Neigle [before 1726], facsimile ed., ed. by Alfred Berner, Kasse1: Bärenreiter, 1961), blatt 14.

112 Weigle, IX. 
DLimE 9



CLARINET'T.

The earliest representation of a clarinettist from Johann Christoph Weigle, Musicalisches Theatrum (Nurnberg: J.C. Weifle [before 1726], facsimile ed., ed. by Alfred Berner, Kassel: Burenreiter, 1961), blatt 14 . 
caption to this interesting engraving is given here:

\section{CLARINTTT.}

Wañ Der Trompeten-Schall will allzulaut erthbnen so Dient das Clarinet auf angenehme weiss

es darff Den hohen-Thon auch niedern nicht entlehnen

und wechselt lieblich um: Ihm bleibt hierdurch der preiss. Darum manch Edler Geist. Dem dieses werck beliebet

Sich Lehr-begierig zeigt und embsig Dariñ lubet.

\section{CLARINET.}

Fhen the trumpet call is all too loud,

The clarinet does serve to please

Eschewing both the high and lowest sound,

It varies gracefully and thus attains the prize.

Wherefore the noble spirit, enamoured of this reed,

Instruction craves and plays assiduously. 113

Feigle's comparison of the clarinet's sound to that of the trumpet is significant. It has even been suggested that the name clarinet is merely a diminuitive of clarino, since these instruments sounded so similar. 114 Weigle died in 172.6 so Eitner's dating of Musicalisches Theatrum as c. 1740 is shown to be inaccurate. 115

$$
\begin{aligned}
& 113 \mathrm{Kroll}, 51 . \\
& 114 \mathrm{Renda11,} 1 .
\end{aligned}
$$


hundert," 273; trans. by Don Halloran, 4. Becker did not provide a source where Eitner dated this work and it cannot be found in Eitner's Quellenlexicon. 
A few years after :ieigle's engravings appeared, Walther wrote the first definition of the clarinet under this name in his rusikalisches Lexicon (1732). Interestingly, he makes the same comparison of the sound of the clarinet to that of the trumpet:

Clarinetto, ist ein zu Anfange dieses Seculi von einem Nilunberger erfundenes, und einer langen Hautbois nicht ungleiches hyltzernes Blass=Instrument, ausser dass ein breites Mund=Stuck daran begestiget ist; klingt von ferne einer Trompete ziemlich Hhnlich, und gehet vom $F$ bis ins d'M durch die Tab. IX.F. 1. angezeigte KIHge. 116

Clarinet, A woodwind instrument invented at the beginning of this century by a Nuremberger. It resembles a long oboe, except for a wide mouthpiece, from afar the instrument sounds not unlike a trumpet. Its compass extends from $F$ to $d$ ' shown in table IX, figure one. 117

Tialther quoted Doppelmayr verbatim in his article on Denner, and gave Doppelmayr's book as his source. It is obvious that he is relying on the same source for his initial statement on the clarinet. As Bonanni had done, he also mentions the resemblance of the clarinet to a lons oboe. The "wide mouthpiece" of this instrument is quite characteristic of two-key clarinets as well as for chalumeau instruments. 118 The range that appears in Nalther's table 9



117 Kroll, 21, translation from líajer, Museum Musicum, 39. 118 See, Rendall, 56. 
is only from $f$ ' to $d '$ '', perhaps the lowest octave of $f$ to $f$ ' was unintentionally left out.

Yiajer quotes ilalther almost verbatim on the first fingering chart for the two-key clarinet in Museum Vusicum (1732, plate ten). 119 The only difference occurs in the range that is indicated. Majer writes that the range is from "tenor $f$ to $a^{\prime \prime}$ and sometimes c''"', giving the fingerings from f to a''. The instrument in this chart, similar to that in Weigle's engraving, is seen to be an "improved" two-key clarinet, from the flaring bell and high position of the register key. It should also be noted that the reed is facing the upper side of the instrument, contrary to the present practise of facing it toward the register key. Extant two-key clarinets also support this fact, proving that these instruments were played with the reed pressing against the upper Iip. 120

Zedler in his Universal-Lexicon (1732-54) copied Walther's description in his article, "clarinetto" and Doppelmayr's bio-

119 Majer, Museum Musicum, 39. The same chart and its information is provided in his lieu-erbffneter theoretisch und praktischer Music-Saal, 43.

120 For a discussion of embouchure technique see, IGGG, s.v. "Die europuische Klarinette," cols. 1015-1016; trans. by Dyke Kiel, The Clarinet 2, no. 4 (August 1975): 24; Kroll, 27-28. 
PIATE 10

\section{4gas: ) 0 ( agas:}

S. 16.



The earliest illustration of a fingering chart for the two-key

clarinet from J.F.B.C. Majer, Museum Musicum (Schwab. Hall:

Georg Michael Majer, 1732, facsimile ed., ed. by Heinz Becker,

Kassel und Basel: Bärenreiter, 1954), 39. 
graphical sketch in his article, "Denner, Joh. Christoph". I2I Eisel's Musicus Autodidaktos (1738) employs a series of questions for each topic and instrument discussed. His material on the clarinet appears to be based on Najer's Museum Yusicum with a few significant differences. The range indicated is from $f$ to $c$ '', but Eisel adds that "higher notes are not impossible as many virtuosos can play a fifth or a sixth hipher". 122 His fingering chart, from $f$ to c''' (plate eleven), contains some important differences from Majer's, and according to Becker is more accurate. ${ }^{123}$ An important comment occurs under the last question, "What kind of clef does the clarinet use?"

The common, regular sign for this instrument is the $G$ clef, in which case it is treated in the clarino style; yet sometimes the Discant and Alto clefs are found, in which case the clarinet is treated as a chalumeau. 124 Here is further proof of the concurrent use and composing for

${ }^{121}$ Johann Heinrich Zedler, Grosses v8Ilstandiges UniversalLexicon, 33 vols. (Halle und Leipzig: Verlegts J.H. Zedler, I732$1754), 6(1733): 226 ; 7(1734): 569$.

122 Eise1, 76.

123 Becker, "Zur Geschichte der Klarinette im 13. Jahrhundert," 281; trans. by Don Halloran, 15, see, Eugene E. Rousseau, "Clarinet instructional materials from 1732 to CA. 1825," (Ph. D. dissertation, State University of Iowa, 1962), 80-83.

124 Eise1, 78; Becker, Ibid., 273; trans., 4. 
PLATE 11



Fingering chart for the two-key clarinet from [Johann Philipp Eisel], Musicus Autodidaktos (Erfurt: Johann Michael Funcken, 1738), 79. 
both the clarinet and chalumeau, otherwise this question would not have appeared.

Adlung's subsequent comment on the clarinet in his Anleitung zu der musikalischen Gelahrtheit (1758) indicates both an easy familiarity with the instrument, and the initial use of the term chalumeau to describe the lower part of the clarinet's range. 125 "Clarinet ist bekannt. In der Tiefe lautet es anders, als in der Hohe, und alsdenn nennt man es chalumeau". 126 Clarinet is well known. In the low range it sounds differently than in the high range, therefore, one calls it chalumeau. Adlung also refers the reader to ialther's table nine, figure one for the instrument's range.

Reports of the use of the clarinet in Germany begin to appear in the $1730^{\prime} \mathrm{s}$. In 1732, the Mainz court orchestra engaged a clarinettist, by 1739 , Kremsmlinster Abbey had two clarinets, 127 and on 13 October 1739 the Frankfurter Mitteilungsblatter reported: "fdvertisement. Two good clarinettists have arrived at the findmill in All Saints Lane; anyone wishing to hear them perform will be welcome". 128 The first performer on the clarinet and chalumeau, that is known by name, appeared on 12 May 1742 at

125 Still being used in present-day tutors.

126 Jacob Adlung, Anleitung zu der musikalischen Gelahrtheit (Erfurt: J.D. Jungnicol, 1758, facsimile ed., ed. by Hans Joachim Noser, Kassel und Basel: Bärenreiter, 1953), 588.

$127 \mathrm{Krol1}, 47-48$

128 Kroll, 47, Becker, Ibid., trans. by Don Halloran, 3. 
"lieale's New "usick Tall" in Dublin, Ireland. In the Dublin Eercury (11 May 1742, plate twelve) he is billed as Mr. Charles, the Hungarian, Waster of the Irench Horn". But at this concert he played a "concerto" on the clarinet, a "solo" on the hautbois d'amour and a "select piece" on the shalamo, accompanied by "the best hands in the city". The announcement also included a significant note, "T. B. The Clarinet, the Hautbois de Amour, and Shalamo, were never heard in this Kingdom before". This concert vas such a success he was asked to give a repeat of it within the next week. 129 Subsequently, Charles gave concerts in Salisbury, London and Edinburgh, his last being on 20 March 1755 in Edinbur,h.

The clarinet began its popularity in Faris with the addition of two clarinets and two horns to La Pouplinière's orchestra in 1748. 130 In the next year, Rameau scored for it in Zorastre $^{131}$ and again in 1751 in Acanthe et Cephise. ${ }^{132}$ The first edition of

${ }^{129}$ A detailed account of Mr. Charles' activities is given in Weston, Clarinet Virtuosi of the Past, 17-28.

130 See, MGG (1960), s.v. "La Pouplinière," by Paule Chail.lon, 8: col. 212.

131 Lionel de La Laurencie, "Rameau et les Clarinettes," SIMG 9, no. 2 (February 1913): 27-28.

132 Michel Brenet, "Rameau, Gossec et les clarinettes," Le Guide Musicale 49, no. 9 (March 1 1903): 183. 
At the MIUSIC. HALL in Fimmble.nicer,

To-raurrort belng Wedneidny the 1zth of May, $17+2$.

will be performed

A Grand Concert di MUSIC

By Mr. CHAKLES, the HUNCARIAR, Alafes of the lisene? Horn, with his Second; accom. panied by all the bell lian:is in inis City.

$$
\text { Fistl AC'T. }
$$

1. An Overiure with French llorns, calidd, new Pastor Fido;

1. The $6: \mathrm{h}$ Concerta of Signior Gemisinni;

3. A jolo on ite Fierch Hurn, by Mr. Cissiles, 10 new ine Beauly of tial Inlluruent;

4. A Lioncerto on the Clarilues.

Second ACT

1. Mr. Haxdes's Waser - Mufic, with the March in Scipio, and the grand Cliorus in Acslanta;

2. A Concerto on the German Flute, by Mr. Le. ricux;

3. A Solo on the Haubovis de Anour, by Mr. Charles;

4. Signior Hate's Concerso, with Signora Barbarioi's Minuse.

Third ACT.

1. The Overture in Saul, with the Dead March, compoled by MIr. Ha NEL, but aever performed bere before.

x. A feledl Piece on the Shalamo.

3. A Solo on the Violoncello, by Signior Pafqua. liso.

4. The Turkin Mufick in the original Tane, as performed at we Spriag Garden, Vaux.ball, Loodoo.

The Consert to begin at $70^{\circ} \mathrm{Clock}$ in the Evening. N. B. The Clarioce, the Haubois de Amous, and Sbalamo, were never heard in this Kingdom belore. Tickess at 5 s. and $\mathrm{g} d$. each, to be bad at Mr. Neal's and Mr. Manwaring's Mulick Shops, at Bacon's Coffee-houfe, and as Mr. Hocy's in

. Skinner-Kow.

An announcement in the Dublin Mercury of Mr. Charles' first concert, 12 May 1742 from Pamela Weston, Clarinet Virtuosi of the Past (London: Robert Hale, 1971), 23. 
the Encyclooédie in 1753 describes the clarinet only as a "sorte de hautbois", and refers the reader to the "Iutherie" plates as well as "voyez hautbois". There is no information on the clarinet in the article on the oboe, but the drawing of the two-key clarinet in the plates is reminiscent of the outline of the contemporary oboe (see, plate thirteen). 133 In fact, it was probably not based on an actual clarinet. ${ }^{134}$ Later reports of its use in Paris apnear in the Mercure de France as: a symphony by J. Stamitz "avec clarinets et cor de chasse" (26 Narch 1755), several symohonies with clarinets by Filippo Ruggi (April 1757), a symphony with clarinets by Schencker, and the Dies Irae with clarinets and horns by Gossec (1761). 135

The last discussion of the clarinet before Roeser's Essai, hitherto unmentioned in the literature, appears in the encyclopedia of F.A.P. Garsault, Notionaire, ou mérnorial raisonné (1761). ${ }^{136}$ De Garsault classifies the clarinet under the heading of "Instruments

133 Encyclopédie... Recueil de Planches, vol. 5, plate 8. 134 See, Eric Halfpenny, "Castillon on the Clarinet," Music and Letters 35, no. 4 (October 1954): 333.

135 Georges Cucuel, "La question des clarinettes dans l'instrumentation du XVIII ${ }^{e}$ siecle," ZIMG 12, no. 10 (July 1911): 281. Many more reports of the use of the clarinet in Europe, at this time, can be gathered from Rendall, Kroll, Weston and Robert Austin Titus, "The solo music for the clarinet in the eighteenth century" (Ph. D. dissertation, State University of Iowa, 1962).

${ }^{136}$ François Alexandre Pierre de Garsault, Notionaire, ou mémorial raisonné (Paris: Guillaume Desprez, 1761). 
PIATE 13

Fig, 26 .
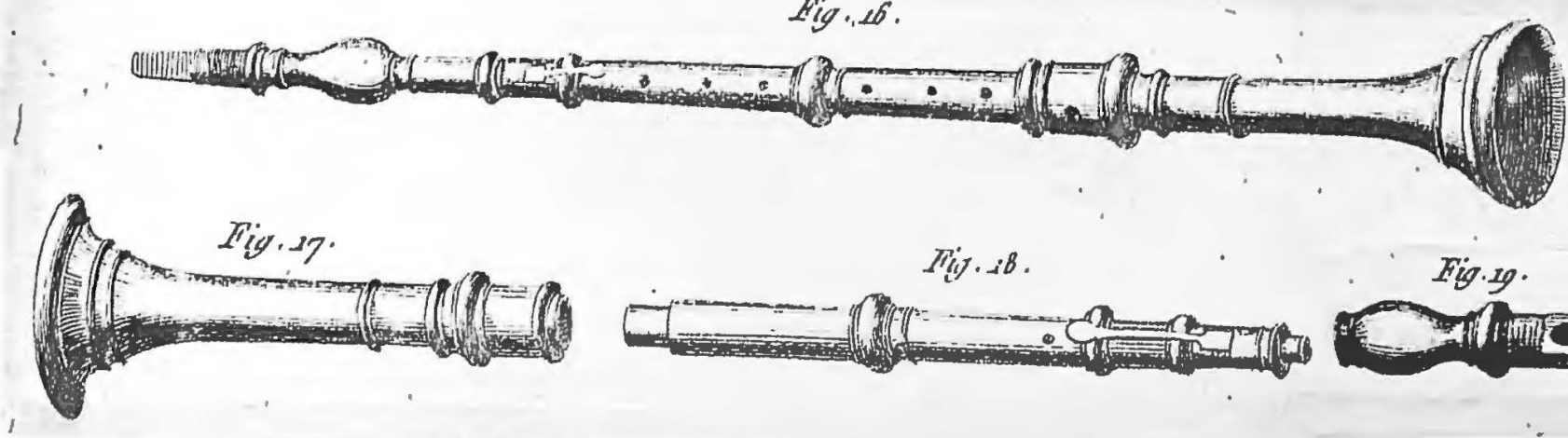

Iiti. is.

Fig.y.

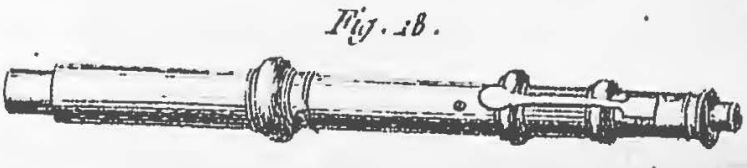

A

A two-key clarinet from the Encyclopédie... Recueil de Planches

(Paris: Briasson, David, Le Breton, 1767), vol. 5, plate 8. 
de Guerre \& de Chasse", describing it as "a vent \& embouchure de Chalumeau. Le Clarinet ou Haut-bois de forêts, joue avec les Cors de Chasse dans les Concerts". 137 In his plate thirty-one, the clarinet is surprisingly depicted as a two-key instrument with a hunting horn (plate fourteen), an instrument it had been associated rith earlier in Faris and London. 138 De Garsault's article follows:

Ie Clarinet est un instrument à vent, a la quinte des tons, c'est-à-dire, que son amila est à la quinte au-dessous de l'amila des dessus, ce qui l'oblige a transposer toujours, puisqu'il doit sonner mi pour se trouver à l'unisson des Violons, Haut-bois, \&:c. C'est ce qui fait encore qu'il faut être muni, quand on joue de cet instrument, d'autant de Clarinets que les dessus sont montés sur un amila plus haut ou plus bas. Il a en récompense l'avantage d'être gai \%: sonore, \& de faire tres-bien dans les Concerts mêlé avec les Cors-de-Chasse. Il est rare qu'il réussisse seul à cause de la dureté du son qu'il est difficile d'adoucir. Il a une embouchure particuliere, c'est d'être sendu en long par le bout d'en haut: cette sente, longue d'un pouce $\%$ plus, mise dans la bouche, rend en soufflant un son de Vuzette ou de chalumeau champêtre. On le tient en avant comme le Hautbois.

Il a dix-neuf pouces de long, \& est percé de dix

137 De Garsault, 633.

${ }^{138}$ In 1754, the London Public Advertiser announced "By particular Desire, between the Acts, will be introduced several pieces for Clarinets and French horns", see, Adam Carse, The orchestra in the XVIIIth century (Cambridge: W. Heffer \& Sons, 1948, reprint, liew York: Broude Brothers, 1969), 130. 
PLATE 14

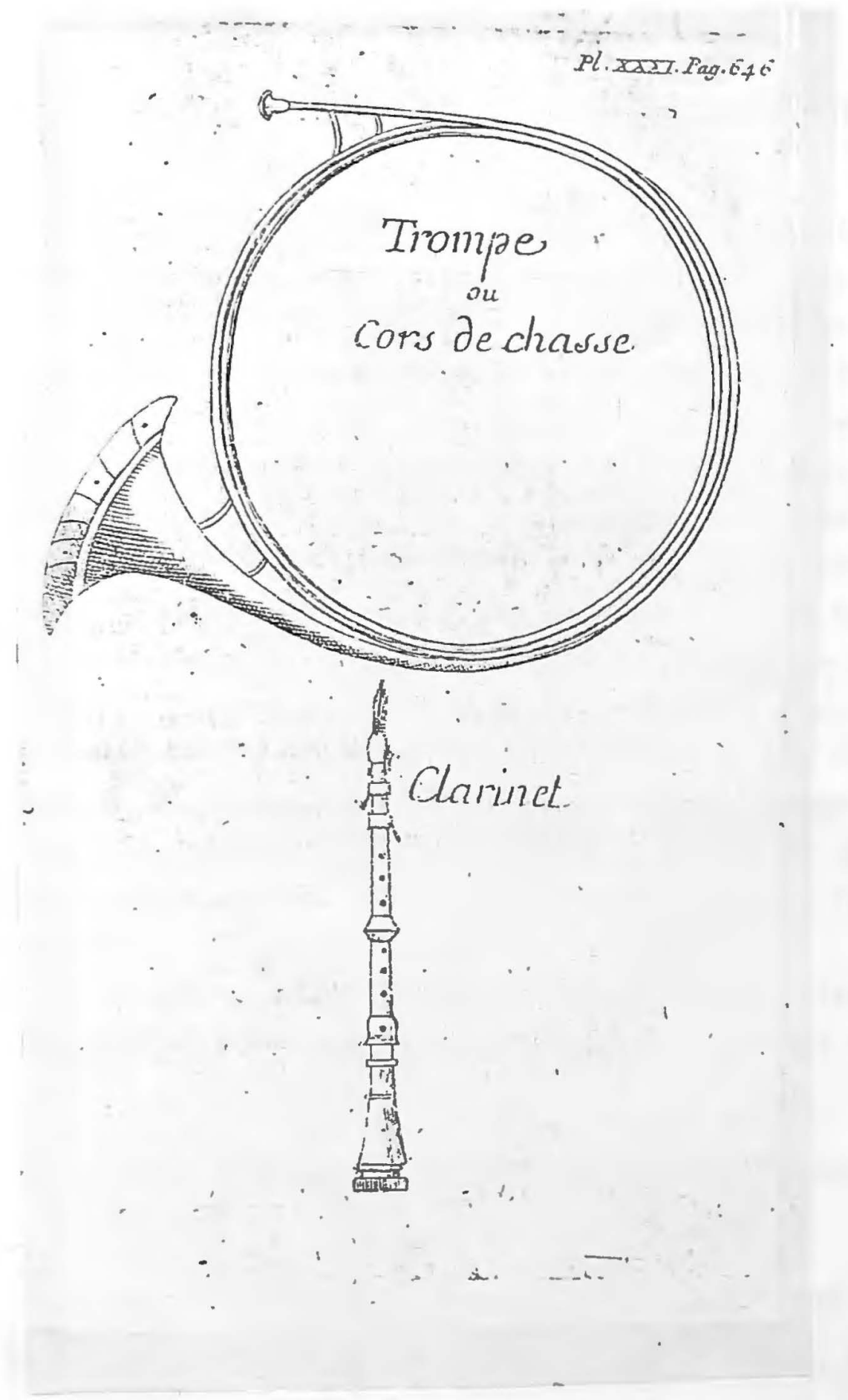

A two-key clarinet in high F from F.A.P. de Garsault, Notionaire, ou mémorial raisonné (Paris: Guillaume Desprez, 1761), 646. 
trous, dont les deux d'en haut sont bouchés avec des clefs.

\section{Etendue.}

tave. 139

Du fa au-dessous de son anila au mi troisieme oc-

The clarinet is a wind instrument at the fifth of tones, that is, its $a^{\prime}$ is at the fifth below the $a^{\prime}$ of the treble instruments. Therefore, one is always obliged to transpose since it must sound $e^{\prime}$ to play in unison with the violins, oboes, etc. That is why it is still necessary to be equipped, when one is playing this instrument, with as many clarinets as one has treble instruments that are constructed around a higher or lower a'. It has the advantage of being gay and sonorous and to mix well with hunting horns in concerts. It is rarely played alone because of the hardness of its sound, which is difficult to soften. It has a special mouthpiece that is split in its length at the end. This portion, one inch or more in length, is put in the mouth and produces, with the breath, the sound of the musette or the rural chalumeau. One holds it in front as in the oboe.

It is nineteen inches in length and is pierced with ten holes, of which the two highest are covered with keys.

\section{Range.}

From $f$ below its $a^{\prime}$ to $e$ in the third octave.

De Garsault described a two-key clarinet pitched in F, from the transposition required for its $e^{\prime}$ to sound an $a^{\prime}$, and its length of only nineteen inches. It should be noted that neither 
Walther, Najer, or Eisel mentions the pitch of the clarinets they described. De Garsault hints at the use of lower fitched clarinets, such as in B-flat or C, in order to play in the same octave as lower pitched instruments such as violas or cellos. Rendall found, through examination of several instruments, that two-key clarinets were most often pitched in B-flat, C, and D, but even in high $G$ and $A .{ }^{140}$ Therefore, one can assume that the existence of clarinets pitched in hizh $F$ was fairly common at this time. Significantly, de Garsault's clarinet mixed well with horns but was not successful by itself, because of its hard sound. This attitude reveals a preference away from the earlier soloistic use of the clarinet as a replacement for the clarino, in Germany. at this time, it began to be used as a part of the wind ensemble in France. Interestingly, de Garsault makes the first comparison of the sound of his clarinet which is "gay and sonorous" to that of a rural ("unimproved", soprano) chalumeau. His brief description of the reed on the mouthpiece is the earliest of any tutor or instruction book. 141 The range indicated is also seen to be slightly increased from Majer and Eisel's instruction books. It is tempting to assume that upon arriving in Paris in 1762, Roeser read the following section of Ancelet's Observation sur la musique (1757). Thereby, providing him with an impetus to write his Essai on the clarinet and the horn specifically addressed to composers.

$140_{\text {Rendall, } 69 .}$ ${ }^{141} \mathrm{Cf}$. Rousseau, 118. 
The horns please still more when they accompany clarinets, instruments unknown till now in France and which have on our hearts and on our ears rights which were unknown to us. Of what use they could be to our composers in their riusic ! 142

\section{The music of the two-key clarinet}

Nusic written for the two-key clarinet is only partially extant and quite scarce. The first known work consists of two books of anonymous airs that could have been played on any of the instruments found on the title page: "Airs a deux Chalumeaux, deux Trompettes, deux Hautbois, deux Violons, deux Flûtes, deux Clarinelles ou Cors de Chasse" (see, plate fifteen for the original title page). Both books apnear in the 1716 catalog of Roger \& Le Cene (nos. 348, 349). 143 "Clarinelles" is obviously a printers error since they were advertised in this catalog as "Clari-

142 [Ancelet], Observations sur la musique, les musiciens, et les instrumens (Amsterdam: Aux depens de la compagnie, 1757), 33, quoted in Robert James Macdonald, "François-Joseph Gossec and French Instrumental Music in the Second half of the 18th century," 2 vols. (Ph. D. dissertation, University of Michigan, 1968) 1: $172-173$.

143 Marc Pincherle, Antonio Vivaldi et la Musique Instrumentale, 2 vols. (Paris: Librarie Floury, 1948) 1: 102. This catalog is found in the Berlin Staatsbibliothek and the British Library, see, Becker, "Zur Geschichte der Klarinette im 18. Jahrhundert," 271, trans. by Don Halloran, 34. 
PLAT: 15

\section{AIRSA DFUX CHATUNFAUX}

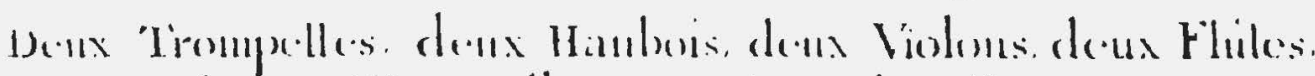

deux C'lanmelles an Coms dr. Chass.

$$
\text { Drilli: }=\text { is }
$$

\section{IONSIFUR IIFNRY IPIRMAN}

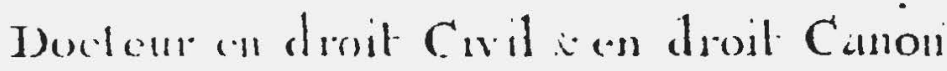

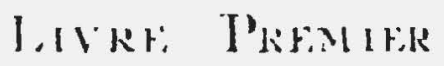

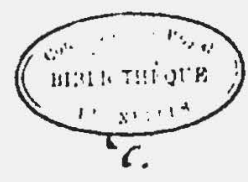

I

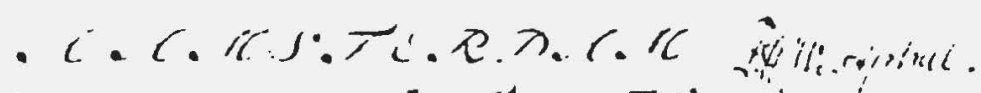

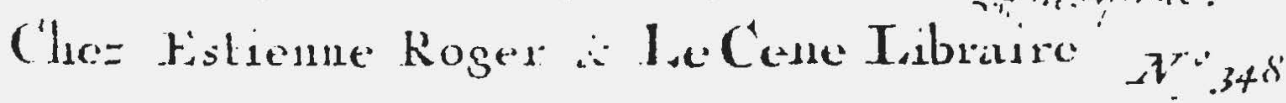

The second edition (c. 1717 to 1722) of the first known works written for the clarinet, Bibliotheque du Conservatoire Royal de Musique, Brussels (classmark 5606). 
nettes". 144 Dart surmised that these books were a second edition since the imprint "Roger \& Le Cene" was only in use from 1717 to 1722. The Airs did not appear in Roger's 1706 catalog, so the first edition must have appeared between 1707 and 1716, however, no copy of this edition is known to survive. 145 The music in these books consists of duets in $D$ and two trios in the second volume, that include a bass part probably intended for kettledrum. 146 About two-thirds of the numbers may be played using only notes of the harmonic series, and so these are suitable for brass instruments. 147

Also advertised in Roger \& Le Cene's 1716 catalog are the "firs à deux clarinettes ou deux Chalumeaux par Mr. Dreux". Jacques Philippe Dreux (flourished c. 1730) is mentioned by Ialther in lusikalisches Lexicon, as a flutist who edited these Airs. 148 Unfortunately, these works are not extant. In 1719, Becker noted that "Clarinetti" was written between the oboes

144 Klarinetten Duette aus der Fruzeit des Instrumentes, ed. by Heinz Becker (Wiesbaden: Breitkopf \& Hurtel, 1954), 2. Numbers $1,2,3,24$ and 60 of the Airs are published in this collection. 145 See, Thurston Dart, "The Earliest Collections of Clarinet Music," GSJ 4 (June 1951): 40.

$$
\begin{aligned}
& { }^{146} \text { Dart, } 40 . \\
& 147 \text { Lawson, } 127 . \\
& 148 \text { Walther, } 218 .
\end{aligned}
$$


and horns in the score to Francesco Conti's opera, Don Chisciotte in Sierra Morena. 149 This is the earliest known orchestral usage of the clarinet. Another early orchestral use appeared when Gévaert published twenty-one measures from the "尺ui tollis" of the mass, "Maria 4ssumpta" (c. 1720) by J.A.J. Faber. 150 Gévaert credits this information to the musicologist, I.P.M. de Burbure. A solo contralto is accompanied by two flutes, clarinet, and cembalo or organ. The clarinet is given arpeggios in the chalumeau register descending to $f$, using a total range of from $f$ to $b$ flat" Gévaert's comment upon this work follows:

The Clarinet seems to have been used in the orchestra in Belgium long before it was known in French, or even in German bands. The archives of Antwerp Cathedral contain a mass written in 1720 by the precentor John Adam Joseph Faber, in which we are surprised to see the Clarinet treated as a concerted instrument. 151

Regrettably, this mass is also lost and the information unverifieà.

Five other reports of the use of the two-key clarinet during the first half of the eighteenth century have appeared. Kappey designated the date 1720-30 for a march, scored for clarinets,

${ }^{149}$ Becker, "Das Chalumeau im 18. Jahrhunderts," 23.

150 François-Auguste Gevaert, A New Treatise of Instrumetation, trans. by E.F.E. Suddard (Paris \& Brussels: Henry Lemoine \& Co., n.d.), 173.

${ }^{151}$ Gévaert, 177. 
oboes, trumpets, and bassoons, entitled Narsch, Prince Anton. 152 Titus found this dating to be improbable because of the repeated use of the note $b^{\prime}$, lacking on the two-key clarinet. Thus, he dated it as being characteristic of the third quarter of the century, when wind bands became popular in Jurope. 153 Telemann used the clarinet in a cantata "on the first Whit Sunday for 1721", according to Henke. A soprano aria is accompanied by "rlauto piccolo, Clarinetto et auartet". 154 A clarinet is also designated in the score of Telemann's opera, Miriway. 155

Handel's use of the clarinet has been discussed and examined by many authors. A copy of his opera, Tamerlano found in the Granville collection of the British Library contains parts marked, "Clar 1" and "Clar 2", in the pastoral aria, "Par che mi nasca". 156 The original version of 1724 utilized two cornetti for this aria.

152 Jacob Adam Kappey, Military Music (London and New York: Boosey \& Co., 1894), 75 .

${ }^{153}$ Titus, "The solo music for the clarinet in the eighteenth century," 46-47.

154 Werner Menke, Das Vokalwerk Georg Philipp Telemann's (Kassel: Bürenreiter, 1942), 39.

155 See, Richard Petzoldt, Georg Philipp Telemann=Leben=und Werk (Leipzig: VEB Deutsche Verlag fur Nusik, 1967), 77-78.

156 See, R.B. Chatwin, "Handel and the Clarinet," GSJ 3 (March 1950): 3-5. 
Rendall has dated the Granville score as between 1740 and 1750.157 Rameau's use of the clarinet in France, has also been under much scrutiny by musicolocists. Scott reported the addition of clarinet and horn parts by Rameau, to his opera, Castor et Follux, in 1738, and in his theater music, Temple de la gloire of $1745 .{ }^{158}$ However, she did not cite a source for this information. Gossec claimed to have arranged clarinets, horns and bassoons in an aria, "Tristes apprets", inserted into a production (c. 1760) of Rameau's Castor et Pollux. ${ }^{159}$

The remaining works written for the two-key clarinet are purely instrumental. Vivaldi specified two "claren" in three concertos. These instruments have been interpreted to signify clarinets by most musicologists. ${ }^{160}$ In two of these concertos the

157F. Geoffrey Rendall, "A Short Account of the Clarinet in England during the Eighteenth and Nineteenth Centuries," PRMA 68th Session $(1941-42): 56$.

${ }^{158}$ Maxyne Mathisen Scott, "The Clarinet in France in the Mid-18th Century," NACWPI Journal 20, no. I (Fall 1971): 14.

${ }^{159}$ See, Franģois-Joseph Gossec, "Notice sur l'introduction des cors, des clarinettes et des trombones dans les orchestres français; extraite des manuscripts autographes de Gossec," Revue Musicale (of Fétis) 3rd year, 5 (1829): 220-221.

${ }^{160}$ See, Walter Kolneder, "Die Klarinette als ConcertinoInstrument bei Vivaldi," Mf 4 (1951): 186; Kolneder, "Noch einmal: Vivaldi und die Klarinette," Mf 8 (1955): 209-210; Rendall, 73; Kroll, 47; MGG, s.v. "Die europylische Klarinette," col. 1017; trans. by Dyke Kiel, The Clarinet, 2, no. 4 (August 1975): 26. 
clarinets are paired with two oboes, the third, subtitled, "Per La Solennità di San Lorenzo" is a violin concerto, with a second "Concertante" violin part. The use of wind instruments in this work is as extensive as that of a Haydn symphony. It comprises two flutes, two oboes, two clarinets and a bassoon. All three concertos are published by Ricordi as Fanna 12, numbers one, two and fourteen (Pincherle 73,74 , and 84). A large range of from $f$ to $d "$ is utilized in these works. The part-writing for the clarinets is mainly in a fanfare-like manner, but occassionally very lyrical, as in the second movement of Fanna 12, number 2 (P. 74). Here the oboes and clarinets play alone in a beautiful dialog.

It should be mentioned that Vivaldi carefully avoided all b'-naturals in each of the three concertos. Two apparent exceptions occur in F. 12, numbers two and fourteen. In number two, in the Largo movement, b'-naturals appear in measure 8-9 of the clarinet part. Kolneder found in the original manuscript, that these notes were notated in the bass clef, concluding that they should be played an octave lower. ${ }^{161}$ In number fourteen, b'naturals occur in the first movement, measures 34,139 and 142 . Each time in an arpeggiated dominant seventh chord on G. Malipiero, the editor, noted that in the last two appearances a $d$ ' was written in the manuscript. It is more than likely that the $b^{\prime}$ in measure 34 was also originally a d'.


Vivaldi," 188, 190. 
In the Hessisches Landes-und Hochschulbibliothek exists the manuscript parts of a trio for "Clarinet, Cornu de Schass et Basso" by "Kulbet. Eitner mentions these parts and identifies the composer as a boherian French horn virtuoso, whose name was Kulbel. 162 In 1730, Kulbel is known to have played second horn at the imperial court in St. Petersburg. For a time afterwards he played in Vienna, and at still a later date, the Dutch ambassador took him to constantinople with his band. By 1754, KBlbel had returned to the Russian court at St. Petersburg and started to build a keyed horn called the Amorschall. This instrument was successfully debuted at the Russian court in 1758, by K8Ibel and his son-in-law, Hensel performing duets in $E$ minor and $F$ major. 163 Kolbel and his invention are not heard of again after this debut. There are four separate parts to the trio. The first, designated "clarinet" is in the key of $\mathrm{C}$, the second part, "Cornu" is also in C. The last two parts are in the bass clef without any designation, the first in $D$ and the other in $C$. These bass parts could have been played as a continuo line or by another wind or

${ }^{162}$ Robert Eitner, Biographisch-bibliographische QuellenLexicon der Musiker und Musikgelehrten (Leipzig: Breitkopf und Hurtel, 1898-1904, 10 vols., reprint ed., New York: Musurgia, 1947), 5: 403, see, Jan Bohumir Dlabat, Allgemeines historisch Kunst-lexicon fur Bbhmen, 3 vols. (Frag: G. Hesse, 1815, reprint ed., Hildesheim: Olms, 1973), cols. 84-85.

${ }^{163}$ See, Horace Fitzpatrick, The Horn and Horn Flaying and the Austro-Bohemian Tradition from 1680 to 1830 (London: Oxford University Press, 1970), 107-108. 
string instrument. There is no figured bass notation and it does not seem to be very idiomatic for the organ. Both the clarinettist and hornist could have easily changed their tonalities from $D$ to $C$, if desired, by the use of pièces de rechange ${ }^{164}$ and tuning crooks. This trio consists of three movements (Allegro, fidagio, Allegro) that utilize a range of from $c^{\prime}$ to $g^{\prime \prime}$ for the clarinet. Yblbel did not hesitate to use the highest range of from $e^{\prime \prime}$ to g'" repeatedly in all three movements. The partwriting for the clarinet is made up of scale passages, octave leaps and arpeggiated figures (see, plate sixteen for the begining of the first movement). It strongly resembles Vivaldi's concertos in his use of scale passages and thematic material, but calls for a greater technical ability, and uses a higher tessitura throughout the work.

The title page of the trio is marked "a wiens" which probably indicated that KBIbel composed it while he was in Vienna. A. reasonable approximation for Kulbel's stay here, is between c. 1735, after he had returned from St. Petersburg, and c. 1750, when he went to Constantinople. Furthermore, because of the stylistic similarity of this work to Vivaldi's concertos, it is possible to estimate the date of composition at $c$. 1740. KBIbel may have even played the clarinet as his contemporary Mr. Charles had done in Dublin in 1742. This work helps to ease the scarcity of chamber music from the earliest period of the clarinet's history. It is

164 See, Rendal1, 71. 
PLATE 16

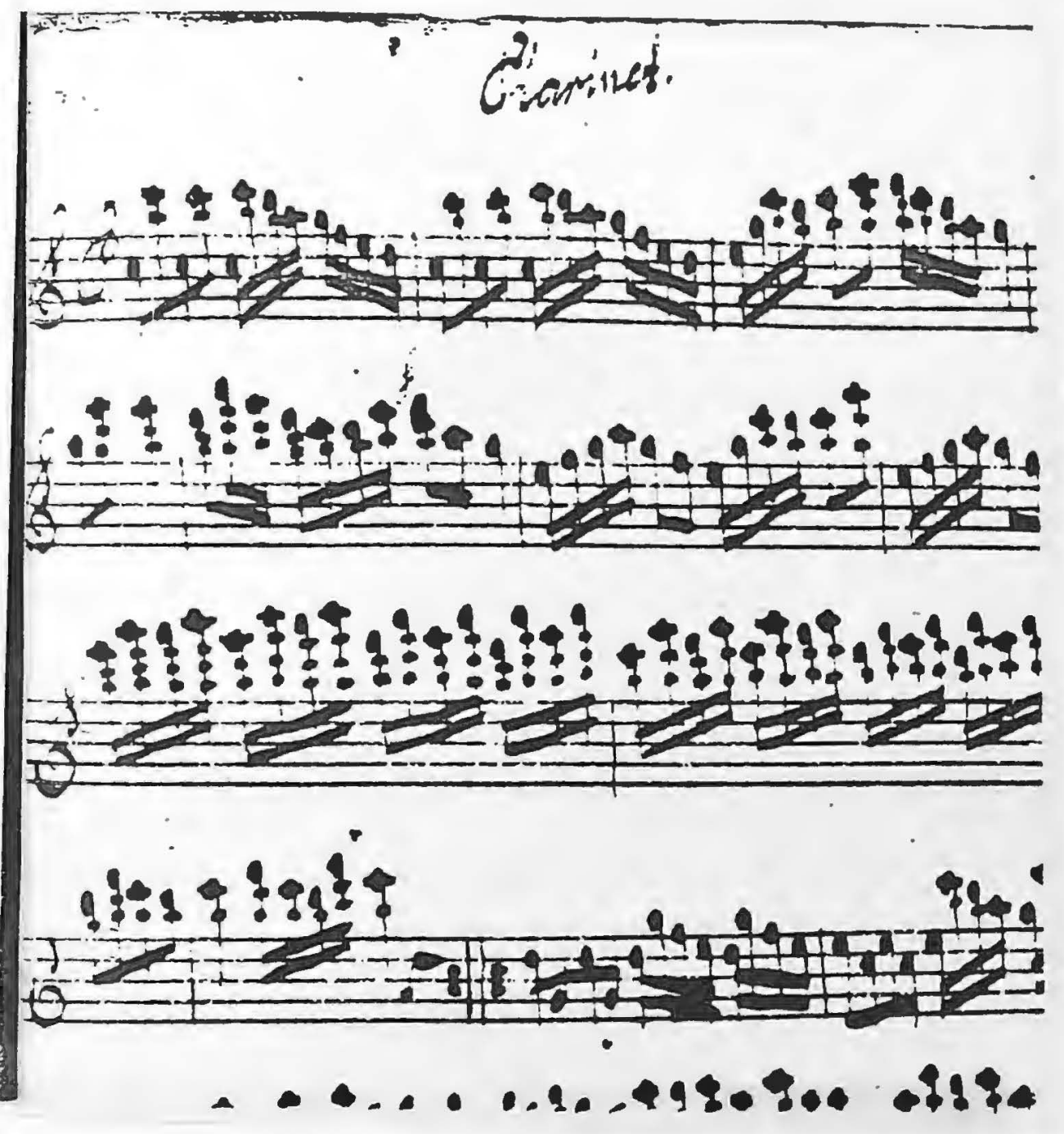

A portion of the clarinet part from the first movement of the Trio for Clarinet, Cornu de Schass et Basso by KBlbel, Hessische Landes-und Hochschulbibliothek, Darmstadt (Mus. 1181). 
still only a partial response to Becker's statement:

Although the pictorial representation of a clarinettist inside a princely apartment in Vieigle's Mus. Theatrum [before 1726] is an important indication of the preference of the instrument in the chamber music of that time, there is no corresponding literature for the clarinet from the first half of the eighteenth century. 165

The earliest known solo concertos composed for clarinet are the six concertos for D clarinet, by the Kapellmeister of Durlach, Johann Nelchior Molter (c. 1695-1765). Four of these concertos have been published in Das Erbe Deutscher Musik, volume 41, another (ms. 332, Karlsruhe, Badische Landesbibliothek) was reconstructed in a D.M.A. dissertation, ${ }^{166}$ the last (ms. 328) remains in manuscript form. 167

The solo clarinet parts are treated in a clarino manner. Their range is from c' to $\mathrm{g}^{\prime \prime \prime}$ (identical to Kolbel's trio) with a very high tessitura, consistently used, between $c^{\prime \prime}$ and $\mathrm{g}^{\prime \prime}$ ' Notes below $\mathrm{c}^{\prime \prime}$ are treated in a purely triadic manner. These concertos are very demanding technically even for today's standards. "Indeed a glance at the Molter concertos indicates that

165 MGG, s.v. "Die europHische Klarinette," col. 1018; trans. by Dyke Kriel, The Clarinet, 26.

${ }^{166}$ Edward Francis Lanning, "The Clarinet as the intended so10 instrument in Johann Melchior Nolter's Concerto 34" (D.M.A. dissertation, University of Missouri-Kansás City, 1969).

167 See, MGG (1960), s.v. "Johann íelchior Molter," by Friedrich Hermann, 3: $\operatorname{col} .447$. 
high technical skill is presumed here, that this in not an early but a mature stage of vriting for the clarinet" 168 (see, plate seventeen for the clarinet part of the first movement of rolter's concerto in A). Nolter designated the parts and the top line in the scores with the term, "Clarinetto" or "Clarinetto Concertato" in the four published concertos. Throughout his works, he carefully distinguished between clarinet and clarino as well as chaIumeau.

Becker compared a clarino concerto of Molter's to one of the clarinet concertos, disproving the idea that it had been written for clarino. In dating these concertos, he relied on information about clarinet playing at the Durlach court, found in the court's register. Becker concluded that the concertos were probably written around 1747 for a flutist/clarinettist by the name of Johann Reusch. This year also coincides with the reorganization of the court chapel. 169 Molter's concertos clearly substantiate the assertation that the clarinet, in its early history, truly acted as a replacement for the difficult

168 EDM, vol. 41, "Klarinetten-Konzerte des 18. Jahrhunderts," ed. by Heinz Becker (Hiesbaden: Breitkopf \& Hurtel, 1957), vii, trans. and quoted in Elsa llarie Ludewig, "A Study of Published Clarinet Concertos before the Mozart Clarinet Concerto" (M.A. thesis, University of Rochester-Eastman School of Music, 1963), 27.

${ }^{169}$ Becker, "Zur Geschichte der Klarinette im 18. Jahrhundert," 287-290, trans. by Don Halloran, 26-30. 




W

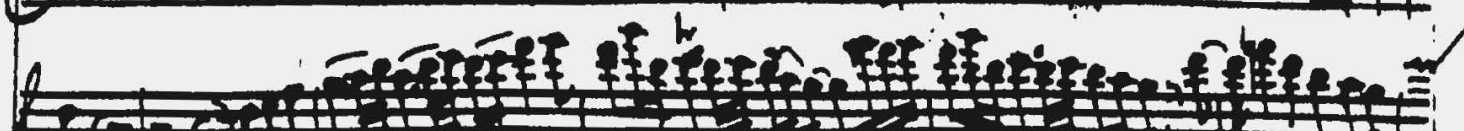

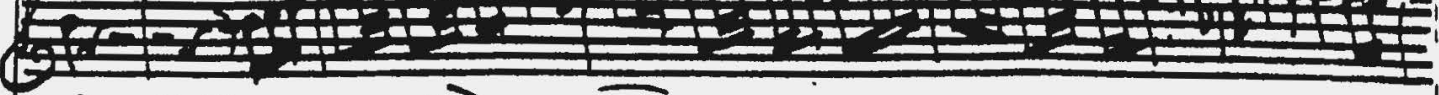
19y W12


W11 Def Molter, Badische Landesbibliothek, Karlsruhe (NS: 304 ). 
clarino trumpet.

This concept of the sound of the clarinet changed within the next ten to fifteen years. It appears to have happened after the addition of keys to the original two-key instrument. The first firm evidence of these addition appears in Valentin Roeser's Essai of 1764. Speaking of the b' and c''-sharp keys Roeser states: "Ces deux clefs ont eté adjoutées il n'y longtemps"170 (These two keys were added not long ago). Of the previously popular D clarinet he said:

Mais on doit en excepter la Clarinette en D, pour le D Mineur, à cause de la petitesse de l'instrument qui ne peut supporter la grande Clef corme les autres, par la quelle on fait $I$ 'Ut\# dans la seconde Octave. ${ }^{17 I}$

But one must except the clarinet in D for D minor. Because of the smallness of this instrument it cannot support the large key like the others, on which one plays the c-sharp [c''-sharp] with it in the second octave.

If Roeser was alert to the improvements of his own instrument, he was probably referring to a time of not less than about fifteen years. Rameau's use of the three-key clarinet in Acanthe et Cephise (1751) has been documented by archival records and

${ }^{170}$ Valentin Roeser, Essai d'instruction à I'usage de ceux qui composent pour la clarinette et le cor (Faris: Mercier, 1764, reprint ed., Geneve: Minkoff Reprint, 1972), 10.

$171_{\text {Roeser, }} 5$. 
the surviving parts in the score. 172 Therefore, it may be concluded that at least in Earis, the clarinet was by mid-century a three-key instrument. Even though elsewhere, clarinet playing might have been restricted to the limitations of the twokey model. 173

De Garsault's Notionaire indicated that high pitched twokey clarinets were used in Paris as late as 1761. One musical example of this older trend is Handel's trio for two clarinets and horn (c. 1754), written for a three-key D clarinet. 174 It still exhibits a pronounced trumpet idiom in its part-writing for the clarinets. 175 Only with the appearance of the Johann Stamitz concerto $(c .1755)$ is a more Iyrical treatment of the instrument evident. This work, the first solo concerto written

172 See, Michel Brenet, "Rameau, Gossec et les clarinettes," Le Guide Musicale 49, no. 9 (March 1 1903): 183-185; 49, no. 10 (March 8 1903): 203-205; 49, no. 11 (March 15 1003): 27.7-228, Georges Cucuel, Etudes sur un orchestre au XVIII siecle (Paris: Fischbacher, 1933), 20.

173, See, Titus, "The solo music for the clarinet in the eighteenth century," 32-34.

${ }^{174}$ George Frederic Handel, Sonata in D Major, ed. by J.M. Coopersmith and Jan LaRue (Bryn Mawr, Pennsylvania: Mercury Music Corporation, 1950), [I].

175 See, Chatwin, "Handel and the Clarinet," 7, Thurston Dart "Handel and the Clarinet," Musical Times 90, no. 1317-1318 (November-December 1952): 510. 
for the B-flat clarinet, was definitely intended for at least a three-key instrument, because of the consistent use of b'-naturals in the clarinet part. 176

Three reasons can now be summarized for the new treatment of the clarinet at this time. First, the general stylistic change that was occurring in music around 1750; second the addition of the third and fourth keys gave a greater security of intonation and technique to the entire range of the clarinet; and third, a preference for the lower pitched clarinets in C, B-flat and $A$ was becoming more evident.

176 See, Peter Gradenwitz, "The Beginnings of Clarinet Literture," Music and Letters 27, no. 2 (April 1936): 145-150. 


\title{
CHAPTER II
}

\section{BIOGRAPHICAL SKETCH CF THE LIFE \\ AND WORKS OF VALENTIN ROESER}

\begin{abstract}
Life
Valentin Roeser, composer, author and clarinettist, was born in Germany about 1735 and died, nrobably in Faris, about 1782. His German origins are considered to be beyond doubt by Barry Brook; ${ }^{I}$ but Riemann's assertion that he was a student of Johann Stamitz is without proof and must be considered as an hypothesis.? Roeser's opus 1 is a set of six-movement orchestral trios that seem to have been written using Stamitz's orchestral trio, opus I, as a model. Roeser also arranged movernents from several Stamitz works, mainly andantes and minuets from opus 1, in his Six Sonates pour le clavecin, avec accompaọnement d'un violon, tirées des ouvrages de J: Stamitz, Suite première (Paris: Bureau d'Abonnement musical, 1768)..$^{3}$ Recently, there has been some speculation that Roeser might have been the copyist of the J. Stamitz symphony $4 \mathrm{~A}$

$I_{\text {MGG }}$ (1963), s.v. "Roeser, Valentin," by Barry S. Brook, 11: $\operatorname{col} 616$.

2 2 TPB, vol. 28, Jahrgang XVI, ed. by Hugo Riemann, XXI. 3 DTB, XIX, XXI.
\end{abstract}


in the FUrstliche Thurn und Taxissche Hofbibliothek of Regensburg. ${ }^{4}$ The upper right-hand corner of the first page of the first violin part of this symphony contains the printed name, "Valentin". If this was in fact, Valentin Roeser, it would seem to support the notion that Roeser was a student of Johann Stamitz, since this manuscript probably originated in Mannheim. However, Roeser's name does not appear in any of the extant lists of Mannheim orchestra members from before 1762. Therefore, confirmation of Roeser's presence in Mannheim as a student or unpaid assistant must await further research. Information about Roeser's life is very limited and incomplete. All of the known facts are recounted here.

He arrived in Paris by 1762 since we find in the Mercure de France (February 1762, page 155) an advertisement for his opus 1 ,

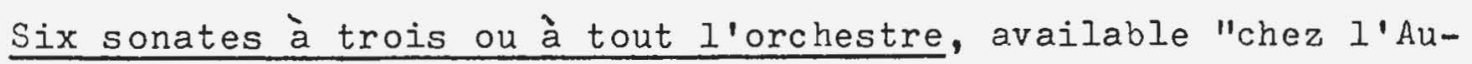
teur, rue de Varenne, a l'hôtel de Matignon". Tublished in Paris by Le Menu later that year, this work was dedicated to the Prince of Monaco and on the title page, below the comnoser's name, was printed, "musicien de sa dite Altesse". Apparently, the prince was living in Faris and Roeser was in his employ as a musician. At this time, Roeser was only one of a number of German musicians who came to the French capital to make their careers, e.g.; Rigel, Burckhoffer, Schobert, Sieber, etc. Gossec suggests in his memoirs that the Seven Years War (1756-1763) caused many musicians to

${ }^{4}$ See, Eugene K. and Jean K. Wolf, "A Newly Identified Complex of Manuscripts from Mannheim," JAMS 27 (Fall 1974): 400-401. 
flee to France especially Faris. 5

During the twenty years that Roeser was living in Faris (1762-1782) we find his name in various frontispieces of his published works and in the contemporary Farisian magazines. The Mercure de France (January 1764, page 143) announced the first of a series of eight instruction books, the lissai d'instruction à l'usage de ceux qui composent pour la clarinette et le cor (Le Menu, 1764). This first book also appeared under the article on Roeser in Choron and Fayolle's Dictionnaire historique des musiciens (1810-11), with the French translation of Marpurg's Die Kunst das Clavier zu spielen (1751), published anonymously as L'art de toucher le clavecin selon la manière perfectionnée des modernes (Le Menu, 1764, Annonces, 18 June 1764).6

In 1766, the prince of Monaco bestowed on Roeser the title of "Virtuoso de Camera de S.A.S. il Principe de Monaco". Three years later he is found to be employed by the Duke of Orleans and is living at "rue Fromenteau, maison de M. Lamy, Horloger" (Annon-

5 François-Joseph Gossec, "Notice sur l'introduction des cors, des clarinettes et des trombones dans les orchestres français; extraite des manuscripts autographes de Gossec," Revue Musicale (of Fétis) 3rd year, 5 (1829): 221.

${ }^{6}$ Roeser's translation of this book was published anonymously probably because Marpurg's book is an adaptation of the text of François Couperin's I'Art de Toucher le Clavecin (1716). See, Ralph Kirkpatrick, "On re-reading Couperin's L'Art de Toucher le Clavecin," Early Music 4 (January 1976): 3-4. 
ces, 3 April 1769). In 1770, Roeser translated Leopold fiozart's Grundliche Violinschule (1756) under the title, rethode raisonnee pour apprendre a jouer le violon (Le Menu, 1770), to which was added at the end of the volume, "YII Fetits Duo et un Caprice Facile". 7 His remaining instruction books appeared as tutors for wind instruments and were published as Gammes (scales) for flute, oboe, clarinet, bassoon and sernent.

It is certain that he had a family in Faris since his son, Charles, published two instrumental works about 1775.8 In 1775 , Roeser was still living at rue Fromenteau and remained in the service of the Duke, of whom he had become a "Pensionnaire" (Mercure de France, June 1775, page 203). By 1730, he had become sufficiently well known to be placed with the outstanding comrosers of the period in F.C. Mehrscheidt's Table raisonnée des Principes de I'Harmonie:

- . quant au fruit que ceux qui veulent étudier à fond les principes de la Nusique pratique peuvent en retirer, on $y$ lit les noms de trois Artistes françois, MM. Philidor, Grétry, et Gossec et de deux Artistes Allemands, MP. Rouser et

7 Wolfgang wrote in a letter to his father during his stay at Paris in 1778: "Now I must say to you that I have the honor of seeing your school of Violin translated in French". Letter of 29 May 1778, The Letters of Mozart and His Family, ed. by Emily Anderson, 4 vols. (London: Macmillan \& Co., 1938), 2: 805.

${ }^{8}$ Six Sonates en trio par Kammel arranges par $\mathrm{Ch}$. Poeser and Trois symphonie en quatuor (Annonces, 20 July, 3 August 1775). 
Rige1 . . 9

- . As to the most outstanding, that those who intend to study the basis of the principles of practical music are able to obtain, one recommends the names of three French artists, r. Fhilidor, Gretry and Cossec and of two German artists, $Y$. Roeser and Rigel...

Gerber in Historisch-biographisches Lexicon der Tonkllnstler (1792) and Choron and Fayolle in their Dictionnaire list Roeser (whose original name was probably Rbser) as being in Vienna in $178 \mathrm{I}$, but there is no evidence to corroborate this statement. After 1782, Roeser's name disappears from the Parisian press so it is probable that this was also the year of his death. The Almanach Musical does not list him in 1783, but the Tablettes de Renommée de Yusiciens, mentioned as "unreliable" by Brook, cites Roeser in 1785 as a "célèbre compositeur" with an address still at the rue Fromenteau. ${ }^{10}$ However, this statement may have been an error by the compilers of this work. Roeser's birthdate of 1735 is only an approximation given by Brook based on the appearance of his opus 1 in 1762 and the publication of his son's first work in 1775.11

${ }^{9}$ Barry S. Brook, La Symphonie Frangaise dans la Seconde Moitié XVIII e Siècle, 3 vols. (Paris: Publications de l'Institut de Musicologie de l'Université de Paris, 1962), 1: 226.

10 MGG, s.v. "Roeser, Valentin," Il: col. 617.

${ }^{11}$ Ibid. 
Of the three Rb́sers listed in Gerber's iveues historischbiographisches Lexicon der Tonkunstler (1.813), the first matches the identity of Valentin Roeser. He lived in Faris and published various methodes, recueils, trios, sonatas and marches. The second RHser was described as "Domkapellmeister zu Linz" and was in Vienna in Cctober 1796, and the third was in 1809, an orsanist and composer in Hungary. However, no further evidence has been found linkine, Valentin Roeser with the last two Rbsers. Van der Straeten in La Musique aux Pays-Bas Avant le XIX ${ }^{\mathrm{e}}$ siecle (1962-85) knew Roeser's opus 10, Six Sonates pour le Clavecin avec Violon obligé as published by D.I. Van Dyk $(D i j k)$ in Amsterdam in the eifhteenth century. He stated that Roeser had lived in Holland teaching harpsichord there, and perhaps also lived in Belfium. He also cited Roeser's harpsichord arrangements of three overtures and a collection of duos and ariettas for harpsichord in the 1776 catalog of the Dutch (?) publisher, Van Ypen. Perhaps these works were republished from the original Tarisian publications. Aside from Van der Straeten's account there is no conclusive proof that Roeser ever lived in Holland or in Belgium.

\section{Works}

Roeser was quite an active composer of instrumental works, writing all types of chamber music from duos for flutes, to six trio sonatas for two violins and bass (that may be rlayed also on the mandoline), to forty military divertissements for two 
clarinets, two horns and two bassoons. He also arranged German dances for two violins and bass, arias from comic operas for two violins, and overtures from operas for string quartet or orchestra. In addition, he wrote twenty-six symphonies, some for large orchestra, as well as translating the treatises of Marpurg and Lcopold liozart. However, not all of his works were purely instrumental since we find some arias for voice with harpsichord accompaniment. This great outpouring of works was typical of a composer in a city, such as Paris, that demanded a larpe production of works for popular consumption. Nevertheless, not everything that Roeser wrote was designed for the amateur musician, and only the professional composer could use his translations and manual of composition for the clarinet and the horn. A chronological checklist of his works is presented in Appendix D. Roeser's music was practically never reviewed by the press, and he was also never singled out for his performance on the clarinet or any other instrument. A single exception to this lack of criticism is encountered in the Journal de Musique, volume 1 (1774), page 63, in a pair of remarks on a collection of duos.

Premier recueil de duo tirés des opéras corniques avec accompagnement de clavecin ou forte piano par Valentin Roeser, Paris, Madame Le Menu. L'idée de ce recueil est heureuse et le choix en est bien fait; mais l'auteur n'auroit pas dûu $\mathrm{y}$ comprendre un trio et encore moins en supprimer une partie pour le ranger avec les duo, parce que c'est le moindre égard qu'on doive aux hommes d'un vrai mérite que 
de laisser leurs ouvrages tels qu'ils sont. 1?

First collection of duos taken from comic operas with the accompaniment of harpsichord or piano by Valentin Roeser, Paris, Madame Le Yenu. The idea of this collection is pleasing and the choice was made very well, but the author should not have had included a trio, cancelling; a part to replace it with a duo. Because the least consideration that one is obliged to give to honest men is that of leavinf their woris such as they are.

In 1780 , liehrscheidt had recognized Roeser as a person well qualified to instruct prospective music students, and the Tablettes de Renommée des Musiciens called him in 1785, "célèbre compositeur connu par nombre d'oeuvres de Symphonies, ?uatuor pour la Clarinette, etc. etc.". Gerber noted in his Historischbiographisches Lexicon der Tonkunstler (1792) that "lir gehtret unter die vorzlglichen neuren Komp.". But as a critic of Koeser's entire works he wrote that he appeared to lack talent and originality in his compositions. 13

Van der Straeten knew Roeser's opus 10 as published in Amsterdam under the following, title: Six sonates pour le piano forte ou le clavecin, avec accompagnement d'un violon. He was fond of these works as revealed by the following comments.

These sonatinas are charming in both their elegant melodic line and in their riquant harmonic progressions. The ideas are small, short and easy but their manner of

12 MGG, s.v. "Roeser, Valentin," II: col. 618. ${ }^{13}$ Ibid. 
presentation gives them interest. ${ }^{14}$

He then cites a few measures of the beginning of the second sonata.

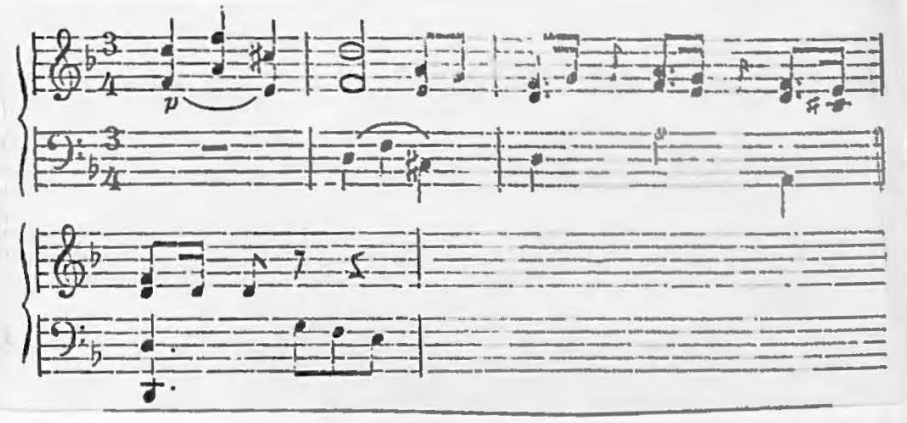

"This beginning is repeated rather successfully in the second period, as follows". 15

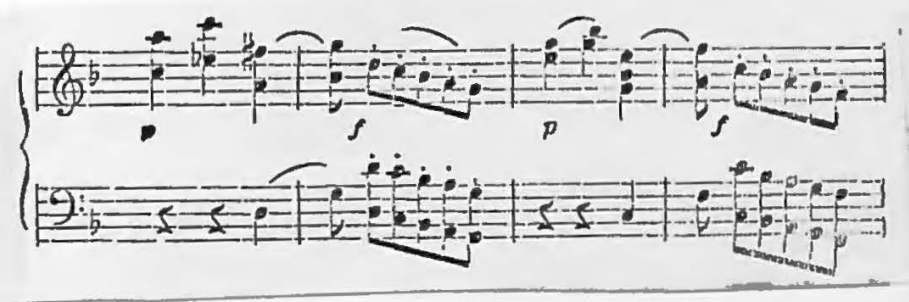

The presence of dynamic marking in this excerpt may indicate a preference by the composer for the piano in these works rather than the harpsichord. Of course it could also indicate a harpsichord with two manuals. Each of these sonatas was given the following descriptive titles, apparently inspired by earlier

14 Edmond van der Straeten, La Musique aux Pays-Bas Avant le XIX siècle, 8 vols. (Bruxelles: C. Muquardt, 1867-88, reprint ed., 4 vols., New York: Dover, 1969), 2: 396.

${ }^{15}$ Ibid., 2 : 397. 
French clavecin pieces: first movement, La Jeannette; second, La Priere; third, La Fensive, Ia Badine; fourth, La Sicilienne, La Sauteuse; fifth, La Frecieuse, La Lutine; and sixth, Neux Polonaise, L'Engagente.

IIIIam Newman in The Sonata in the Classic Era knew these identical six sonatas as Six Sonates pour le forte piano avec accompagnement d'un violon, op. 10. He also noted:

Published in Paris probably in 1774, this set may be the first in the Classic Fra to specify piano alone without the harpsichord alternative. But its contents are hardly so progressive, for they reveal empty pieces in the style and with the characteristic titles of the antiquated pieces de clavecin. 16

After examining another work by Roeser, the Douze [2-mvt.] Jonates tres facile pour le clavecin ou le forte piano, op. 6, Newman ends his discussion of Roeser by dismissing his music as "plain, square-cut, and trite to a degree that discourages further inspection on purely musical grounds". 17

It would certainly be difficult to consider Roeser as a first class composer, "his works are those of a day laborer who zealously carried out his job, with some success, in a city which

16 William S. Newman, The Sonata in the Classic Wra (Chapel

Hill: University of North Carolina Fress, 1963), 661.

17 Ibid. 
has a passion for music". 18 Furthermore, "the importance of the role that Roeser played in Faris went beyond the quality of his own music and the quality of arrangements in the form of 'Gebrausmusik'". 19 He was particularly important in imparting a German musical influence in Paris at this time. For example, one of his earliest compositions reveals his German heritage and the current vogue for German music, the Bal germanique ou $I^{\text {er }}$ Recueil de Danses Allemandes rassemblées et arrangées pour 2 violons et basse (Le Menu, 1764). That same year, he published his manual of composition for clarinet and horn, an important contribution to composers in France. By this time both of these instruments were in widespread use both in Germany and France.

in interest in German music in Paris was encouraged by the visit of Johann Stamitz in 1754 through 1755, and his publication of a popular symphony entitled, La Melodica Germanica (1754).?0 Roeser's admiration for Stamitz and his attempts to further popularize his works is revealed in his inclusion of a three movement sextet for two clarinets, two horns, and two bassoons near the end of his Essai d'instruction. He also had published in

\footnotetext{
${ }^{18}$ Brook, La Symphonie Française, 1: 229.

${ }^{19}$ Ibid.

20 See, MGG(1965), s.v. "Stamitz, Johann," by Peter Graden-
} witz, 12: col. 1152 . 
1768, his opus six, Six sonates pour le clavecin avec accompagnement d'un violon, tirées des ouvrages de Jean stamitz. Suite I (Bureau d'abonnement). Two years later, the translation of Leopold Fiozart's violin school brought an important German work to the attention of the French dilettantes and professional musicians.

In his early works, the orchestral trios, opus 1 (1762), the Symphonie Feriodique ivo. 2 (1762), and four of the Sei uinfonie, op. 4 (1766) he wrote in the style and the four-movement framework of the early llannheim school. ${ }^{21}$ These works lacked the fire of music by Stamitz, and they contained numerous cliches typical anong many of the Mannheim composers of that generation.?2 According to Brook, the first violin part of the third symphony of opus four (plate eighteen) "approaches the Mannheim style of the same period, at least from that which is the melody and the structure". ${ }^{23}$ In measures 22-2.8 of this part we observe a typical succession of dynamic indications from the Mannheim school, F., cres.F., F., piuF., and $\mathrm{F}^{\mathrm{mo}}$. Roeser's later chamber music works were often only two movements in lenfth. A change of style may also be seen in a second series of published symphonies from 1772 to 1776 , after Roeser had lived in Paris more

$2 I_{M G G}$, s.v. "Roeser, Valentin," Il: col. 618 .

22 Brook, La Symphonie Française, 1: 231.

${ }^{23}$ Ibid. 


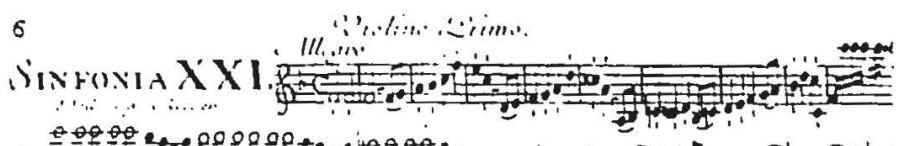



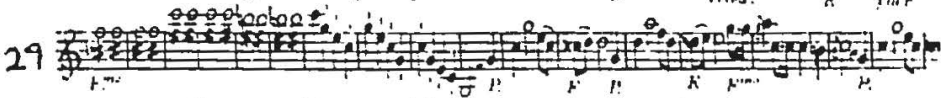



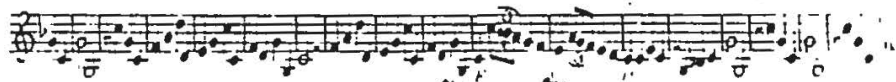

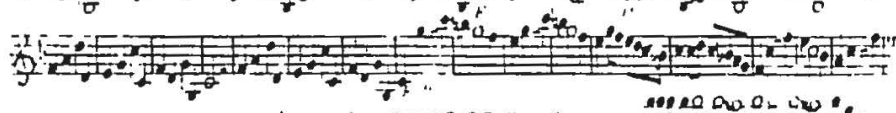

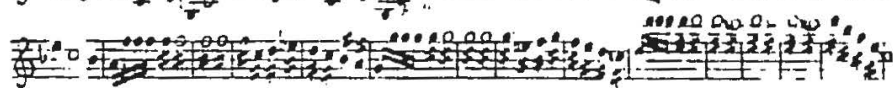

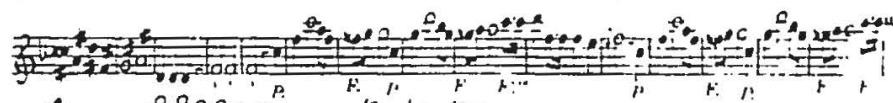
萡

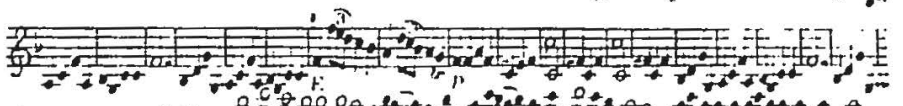


年,



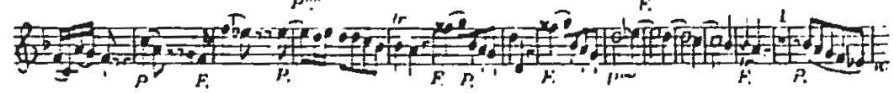

First violin part from the third symphony of opus four by Valentin Poeser, from Barry S. Brook, La Symphonie Frangais dans la Seconde Moitié du XVIII Siècle, 3 vols. (Paris: Publications de l'Institut de Musicologie de l'Université de Paris, 1962), 1: 230. 
than ten years. Now he uses exclusively the trinartite structure which continued to be more generally used in France. 24 Apparertly, by these dates Roeser was truly assimilated into the Farisian musical scene.

24 Ibid. 
CHAFTER III

AI ENGLISH TRATSLATICN OF THE ESSAI RIINCRRLTCTION,

PART ONE: CCITCRRNING THE CLARIXIT

Roeser's Essai shares the unique distinction of being both "the first theoretical study of the clarinet", ${ }^{l}$ as well as "the first treatise of instrumentation ever published". It examines the range and technical possibilities of the clarinet and the French horn, specifically addressing this information to composers. Exercise material is missinf completely, so it cannot be considered a tutor for the performer. The Essai begins a line of French instrumentation treatises that eventually lead to the famous book by Berlioz (1844). The earliest of these treatises by Francoeur $(1772)^{3}$ and Vandenbrock $(1793 \text { and } 1800)^{4}$ still re-

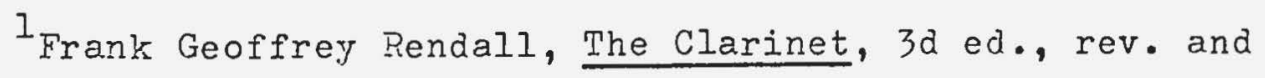
with some additional material by Philip Bate (New York: W.W. Norton, 1971), 76.

2 Heinz Becker, History of Instrumentation, trans. by Robert Kolben (Cologne: Arno Volk Verlag, 1964), 22.

3 Louis-Joseph Francoeur, Diapason général de tous les instrumens à vent (Paris: Le Marchand, 1772).

${ }^{4}$ Othon Vandenbrock, Traité général de tous les instrumens à vent (Paris: Boyer, 1793; Paris: Gavaux, 1800). 
stricted themselves to the wind instruments. $3 \mathrm{y}$ 1910, Froehlich had extended his treatise to all the important instruments commonly used in the orchestra. 5

The following includes a xerox reduction of the first twelve pages of the Essai (concerning the clarinet), with a corresponding تnglish translation. It was prepared from the Minkoff reprint edition (1972) which is published with Amand Vanderhagen's Yéthode nouvelle raisonnée pour la Clarinette (Paris: Boyer, c. 1785).

5 Joseph Froehlich, Vollstundige theoretisch-pracktische Musikschule (Bonn: N. Simrock, 1810-11), Becker, History of Instrumentation, 26. For an English translation of this treatise, see, Eugene E. Rousseau, "Clarinet Instructional Materials from 1732 to CA. 1825" (Ph. D. dissertation, State University of Iowa, 1962), 161-233. 





ESSAY

OF INSTRUCTION.

For the Use of Those Who Compose for

THE CLARINET IND THE HORN.

ith some Remarks on Harmony and some Examples for two Clarinets, two Horns and two Bassoons.

By

IS. VALENTIN ROESER.

Musician of His most Serene Highness, Monseigneur the

Prince of Monaco.

$$
\text { At Paris. }
$$

At MERCIER, à la Musique Royale, Rue des Prouvaires, next to Rue St. Honoré, No. 33.

WITH LICENSE OF THE KING. 


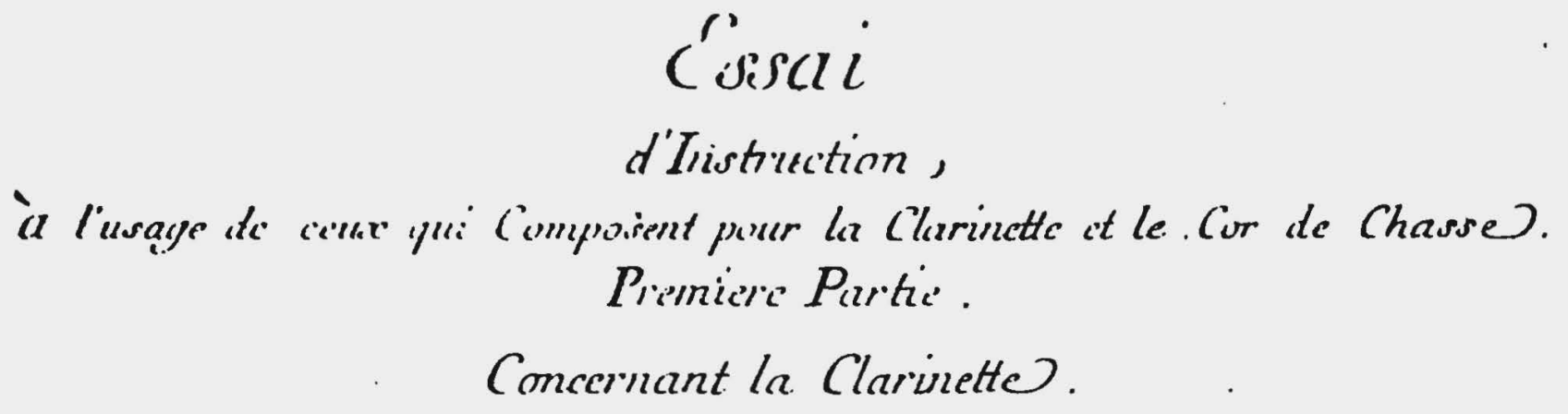

d'Tistruction,

à l'usaye de certur yui (imposient perur la ('lurinatte it le (or de Chasse).

Premicre Purtic .

\section{(encernant la (larinette).}

$$
\text { R. } 1 \text {. }
$$

(omme cet Instrument ast borne' et qu'on ne peut li traiter comme un Hauthois ou. Flute) traversüre, it cit nicessaire dien-avoir de plusieurs ispicies pour jower dans differents tons. Ily m a Sipt ispeces en tout, fcavoir: en G.re, vol, en A, mi, la; en B. fa, si b, mol: en. C,uol, ut ; en D, la, re ; en $E$, si, mi, et en $F$, ut. fa.

$$
\text { ST. } 2 \text {. }
$$

Les arpeces de Clarincites qui sont le plus en usage sont celles en A, mi, la; $B, f a, s i$ b. mol: C, soi, ut, et en $D$, la, re. Celles en $E$, si, mi et en $F$, ut, fa sont triers) aigiies et l'on ne s'en sert dans l'Orchestre que pour les pieces a grand bruit八'. Cills. en G, rc, sol ast la plus douce espece, mais on en trouve rurement, purce qu'elle n'est pas absuliment necessaire, attendu, que pour jouer en $G$, re, sol, on peut se servir d'autis, comme nous le verrons par la suite. Ainvi je ne ferai mention que de cer qua tre ou ring especes: en $\mathcal{A}$, mi, la: $B$, fa, si: $C$, sol, ut i $D$, la, re et $E$, si mi. 
ESSAY

of Instruction

for the use of those who compose for the

Clarinet and the Hunting Horn.

First Part.

Concerning the Clarinet.

pt. I.

As this instrument is limited one is not able to treat it like an oboe or transverse flute, so it is necessary to have several types for playing in different keys. There are seven kinds in all, these are: in $G,{ }^{6}$ in $A$, in $B-f l a t$, in $C$, in $D$, in $E$, and in $F$.

$$
\text { pt. } 2 \text {. }
$$

The types of clarinets that are most often used are those in $A, B-f l a t, C$, and in $D$. Those in $E$ and in $F$ are very high and one only uses them in the orchestra for very loud works. That in $G$ is the sweetest type but one rarely finds any because, it is not absolutely necessary; it is understood that playing in the key of $G$ may be accomplished on the other instruments, as will be seen by the following. Thus, I will only mention these four or five types: in A, B-flat, C, D, and $E$.

${ }^{6}$ Roeser indicated pitches by the use of their hexachord syllables, see, Nilli Apel, Harvard Dictionary of Music (Cambridge, Massachusetts: Harvard University Press, 1968), 331. 


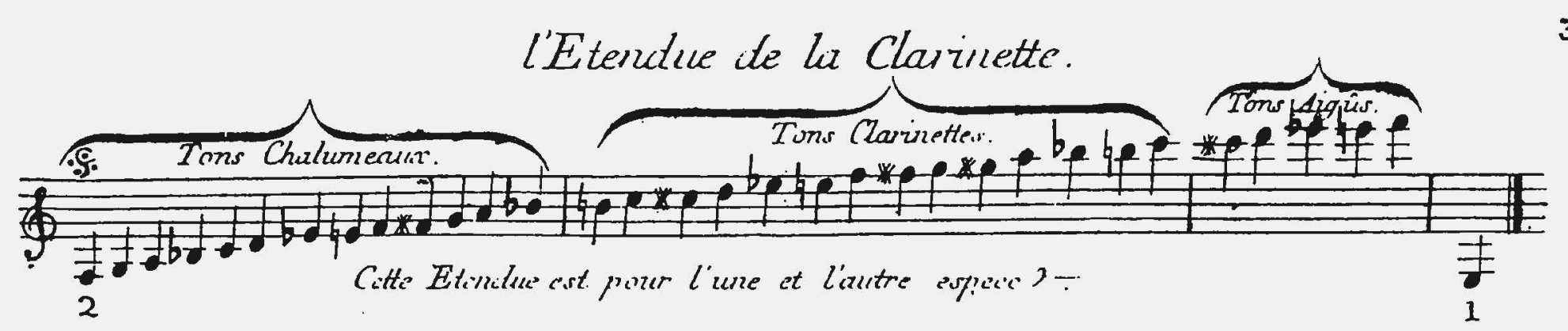

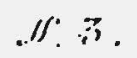

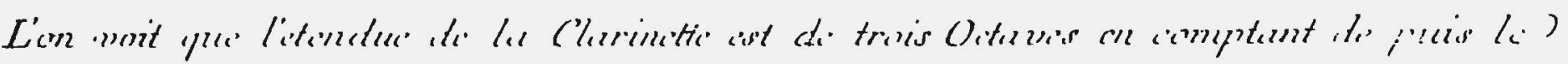

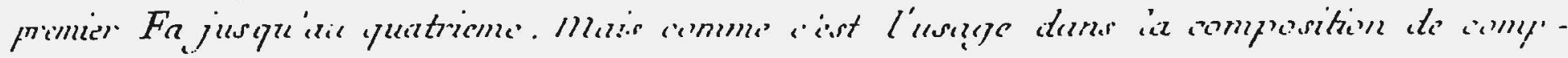

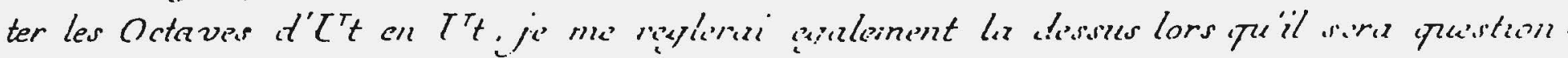

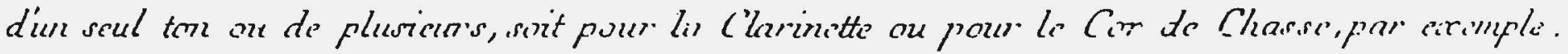

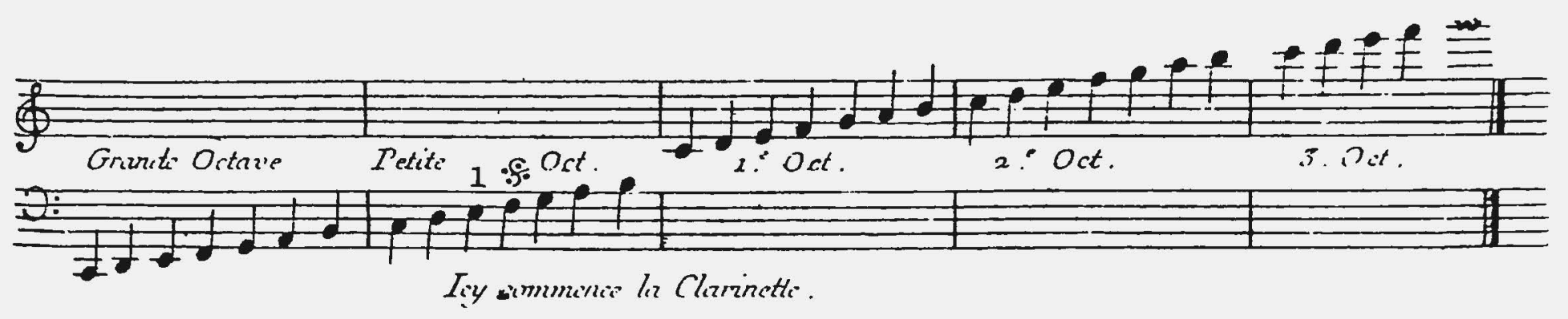

$$
\text { Si } 4 \text {. }
$$

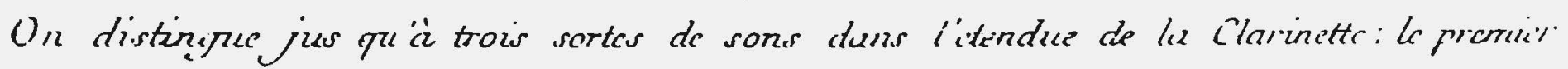

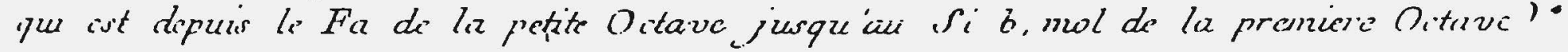





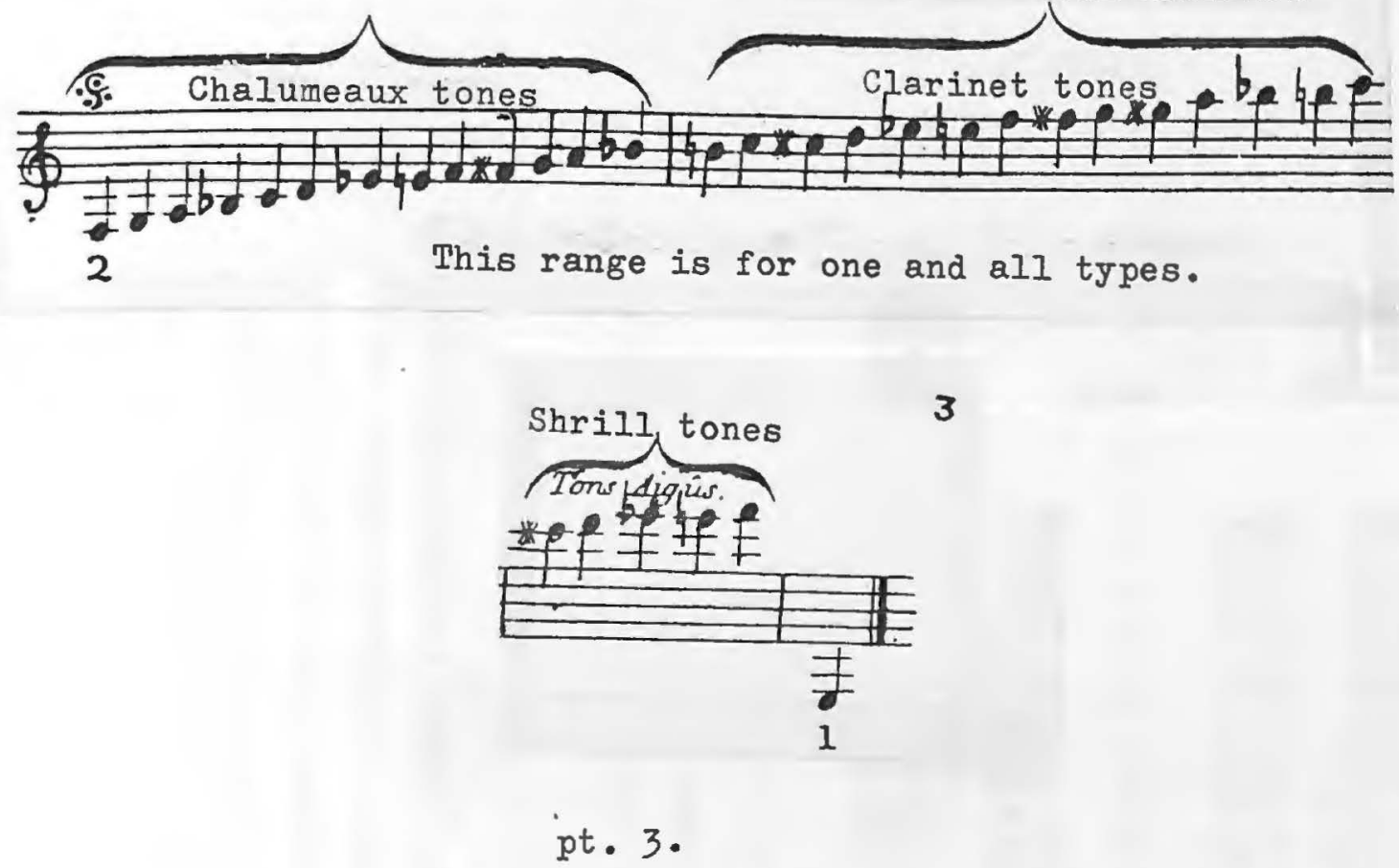

One sees that the range of the clarinet is three octaves, counting from the first $F$ to the fourth [F]. But as it is the practise in composition to number the octaves of $\mathrm{C}$ to $\mathrm{C}$, I will regulate myself also, thereupon, since it will be a question of a single key or of many, even though it would be for the clarinet or hunting horn, for example.
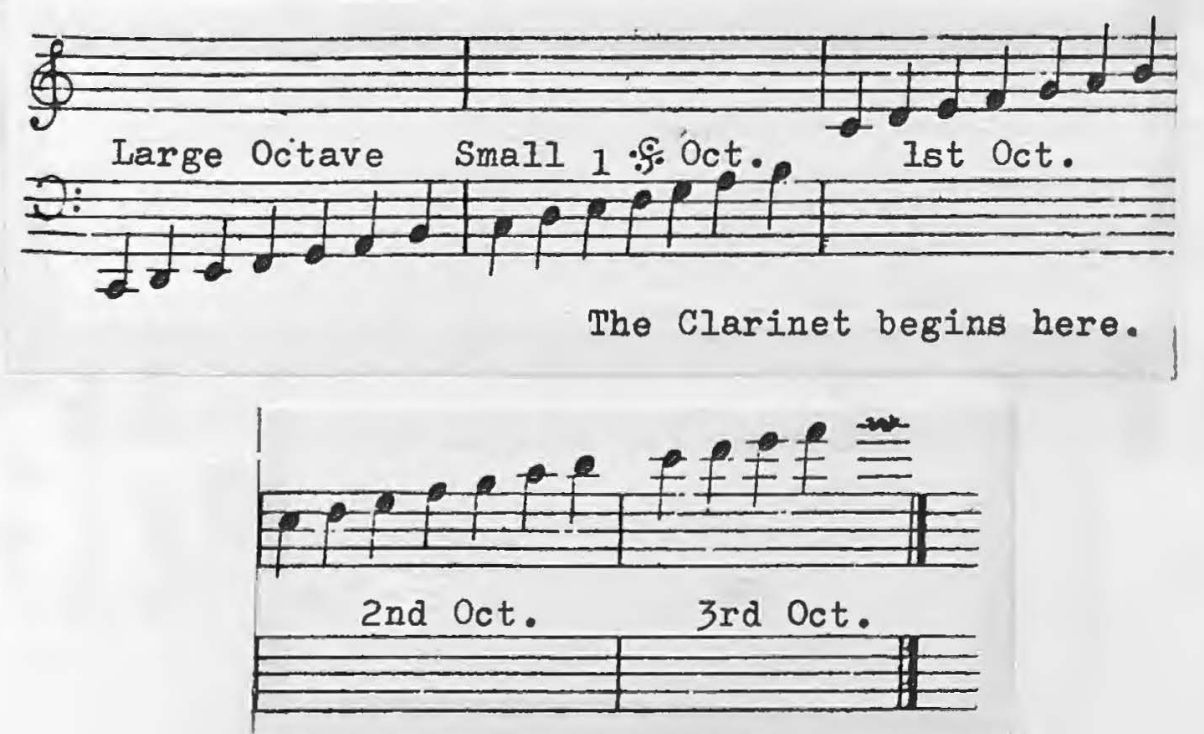
4 rel de la premiere Octave jus qu'ä l'Lt' we la troisieme est appelle' Clairon on Charinette parce qu'il est pliw sonore plus brillant. Le troisienze qui est depriss le $R_{e}$ de liz. troviome Octave jusyu'au Fire, peut être appelle' aioî́. parce qu'il est tries fort et qu' in ne pert l'adoucir comme les précedents. C'est aussi pourquoi lón ne devroit piar s'en sor. vir pour les passages dilicater. J'aurois pu demontiem encore quelques Jimu-tums de flus dans l'etentue de la Clarinette, mais comme its sont ties faua, jai jugé à fropros de lis Sligrimer.

$$
\mathscr{I} .5
$$

Je wais montier maintenant comment on doit se servir de car quatie especar tis $\rightarrow$



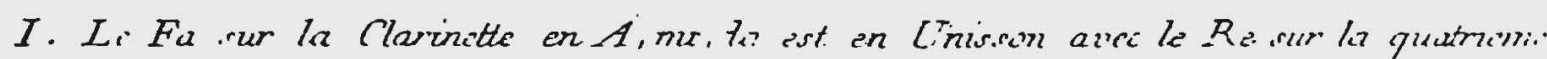
cirrite de la puinte, par iscomple.



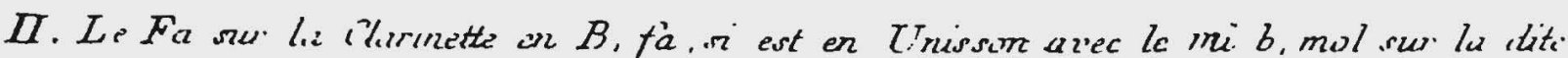
corite te la quinto, puir ex.

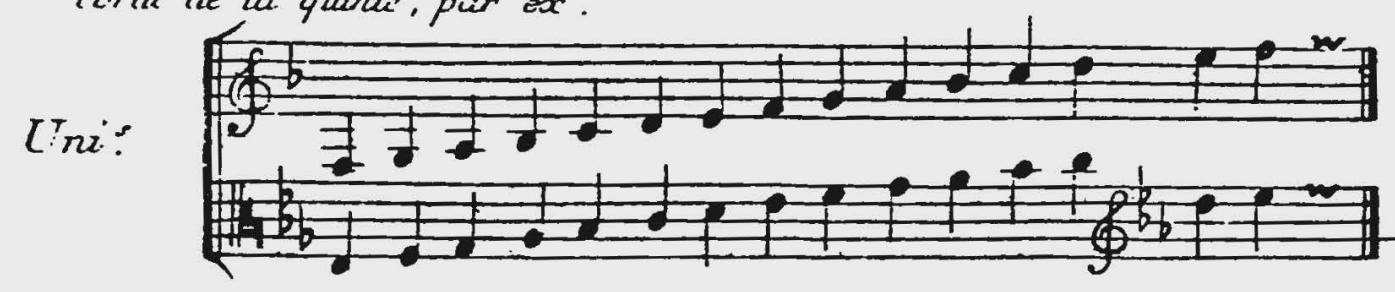


pt. 4 .

One distinguishes up to three types of sounds within the range of the clarinet; the first, which is from the $F$ in the small octave to the B-flat in the first octave $\left[f-b^{b}\right]$ is called chalumeau, because it is very sweet. The second, which is from the B natural of the first octave up to the C-sharp of the third [b'-c\#', $]$ is called clarion or clarinet, because it is very sonorous and very brilliant. The third, which is from the $D$ of the third octave up to $F[d \cdots-f \cdots]$ can be called shrill, because it is very loud, and because one is not able to play as softly in it as the preceding. This is also why one ought never to use it in delicate passages. I could have shown some further semitones in the range of the clarinet, but as these are very out of tune, I have considered it appropriate to leave them out.

$$
\text { pt. } 5 \text {. }
$$

I am now going to demonstrate how one must use the four types of clarinets, by placing them in unison with other instruments.

I. The F scale on the clarinet in $\mathrm{A}$ is in unison with the D scale on the fourth string of the viola, for example.




III. Le Fiu sur la. Clarinette en C, sol, ut, est à. L'unissm aner le Fa sur. la dite corde par ar

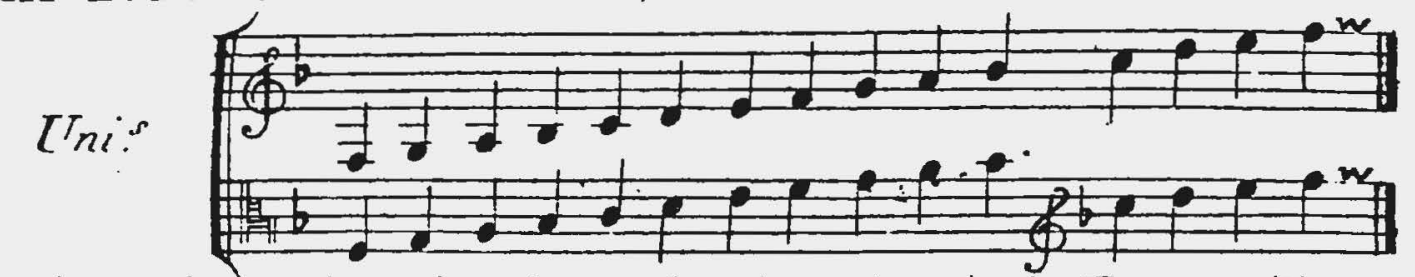



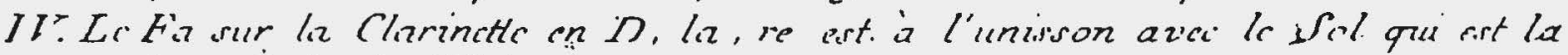
yuitieme curde du Trokn, par ere:

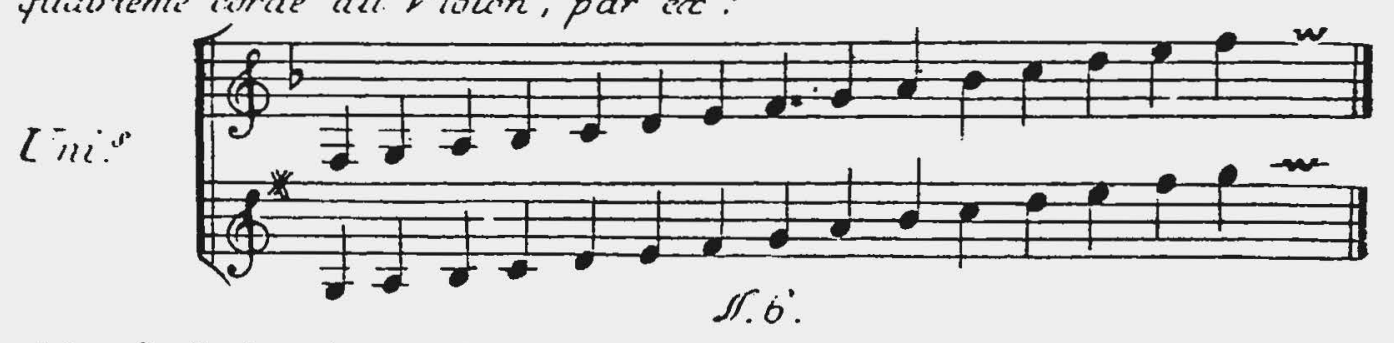

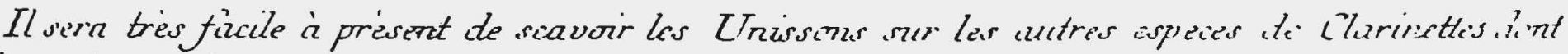
Iai fait mention dans le T.1. nar ex. Li. Fa sur la. Clarinatti en E, si, mi ast ir liunirsum

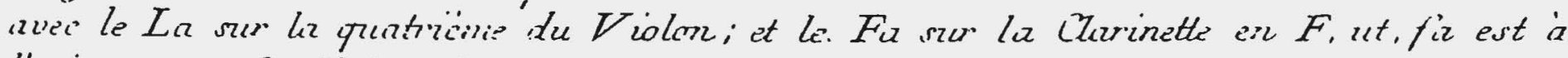

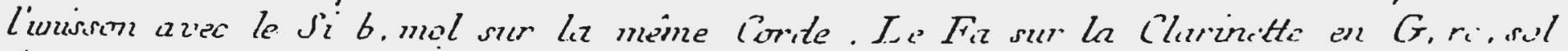

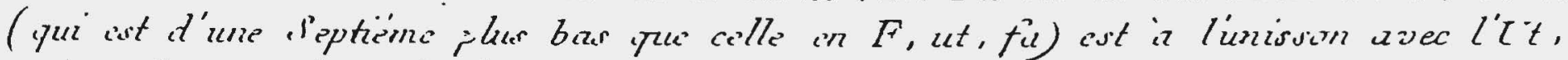
qui est la quatrièmi Corde de la Quintc?.

$$
\mathscr{A} \cdot \vec{j} .
$$

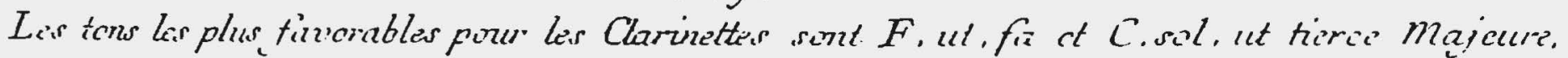

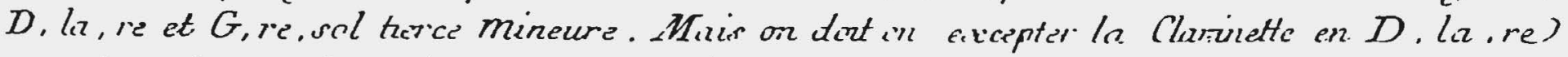
pun. Le D. la re mineur, à sause de la petitesse de l'üstiument qui ne peul supporter la grande ('lef arnme les cutries, prar la quelle on fait l'L't * dans la reconde Octave).

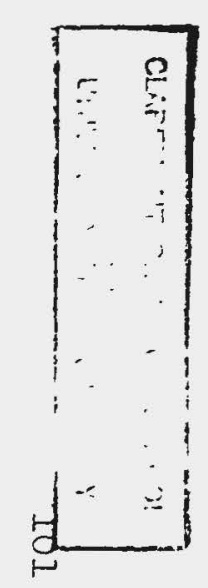


II. The F scale on the clarinet in B-flat is in unison with the E-flat scale on that string of the viola, for ny.

Unis.

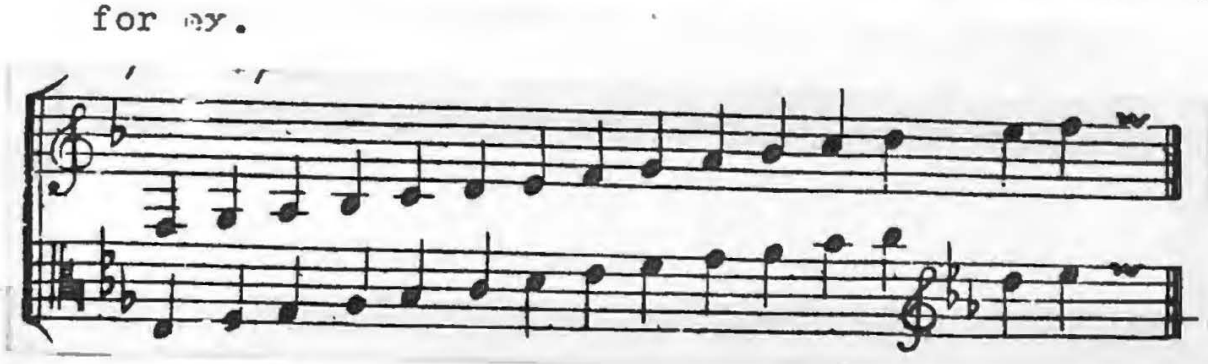

III. The F scale on the clarinet in $C$ is in unison with the F scale of that string, for ex.

Unis.

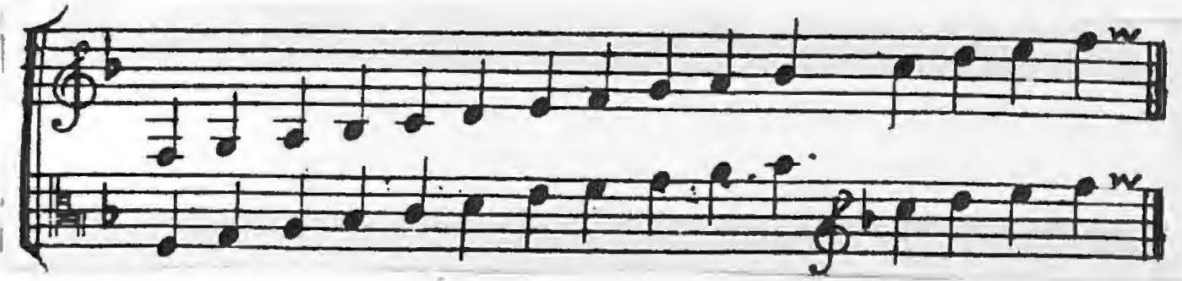

This type is the only one that is not subject to transposition.

IV. The F scale on the clarinet in $D$ is at the unison with the G scale of the fourth string of the violin, for ex.

Unis.

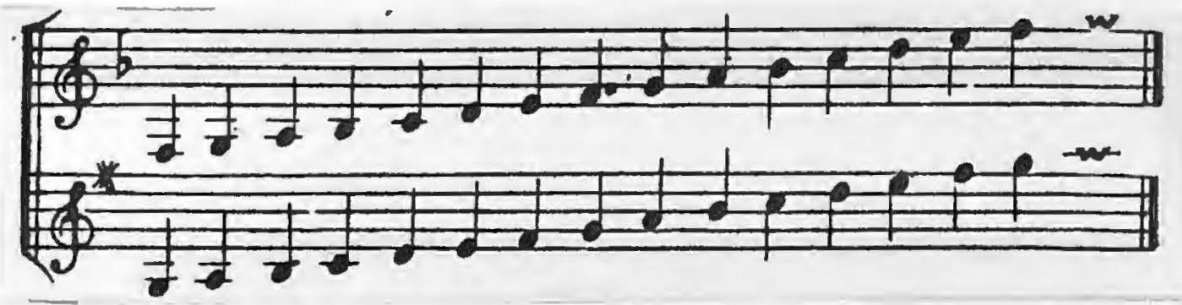

$$
\text { pt. } 6 \text {. }
$$

It will now be very easy to understand the unisons on the other types of clarinets that I have mentioned in pt. 1 for ex.: The F scale on the clarinet in $E$ is at the unison with the $A$ scale on the fourth string of the violin; the F scale on the clarinet in $F$ is at the unison with the B-flat scale on the same string. The F scale on the clarinet in G (which is a seventh 
lower than that in $F$ ) is in unison with the $\mathrm{C}$ scale, which is on the fourth strine of the viola.

$$
\text { pt. } ? \text {. }
$$

The keys that are the most favorable on clarinets are $F$ and. $C$ major, and $D$ and $G$ minor. But one must except the clarinet in $D$ for $D$ minor. Because of the smallness of this instrument it cannot support the large key like the others, on which one plays the C-sharp $\left[\mathrm{C}_{r}, '\right]$ with it in the second octave.

$$
\text { pt. } 8 .
$$

In order that the composer can see at a glance in which key he should write for the clarinets, and which type he should use for each key, I will give an index with some small examples. If one composes in the following five keys, one notates clarinets in C, for ex.:

For the keys, A,

B-flat,

C,

D,

E,
One would use the clarinets, in $A$, see no. $I$.

in B-flat, see no. 2 .

in $C$, see no. 3 .

in $D$, see no. 4 .

in $\mathrm{E}$, see no. 5 .

(See examples page 104). 




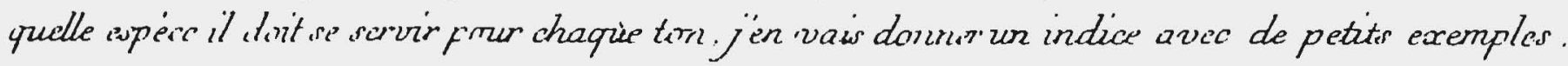


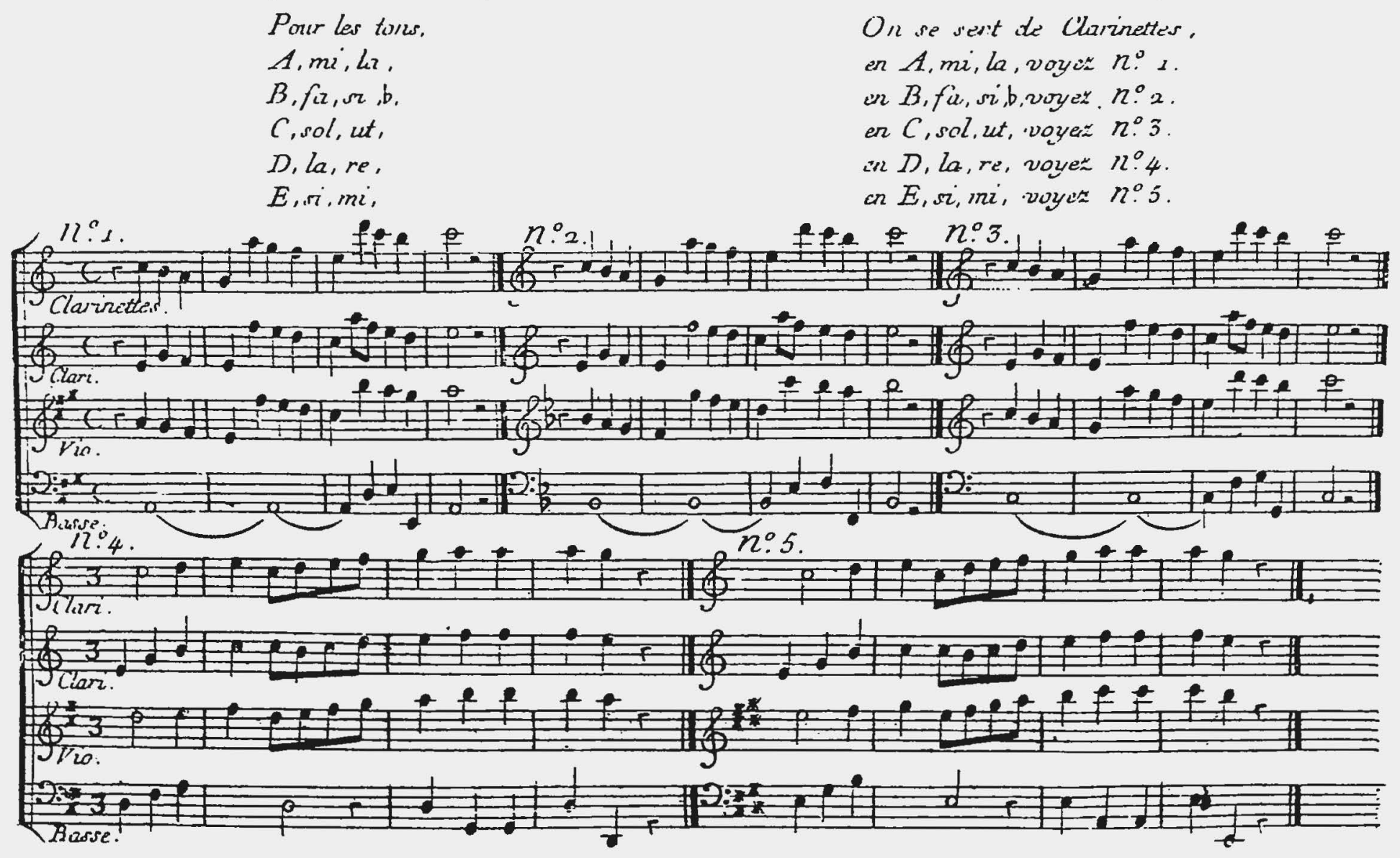


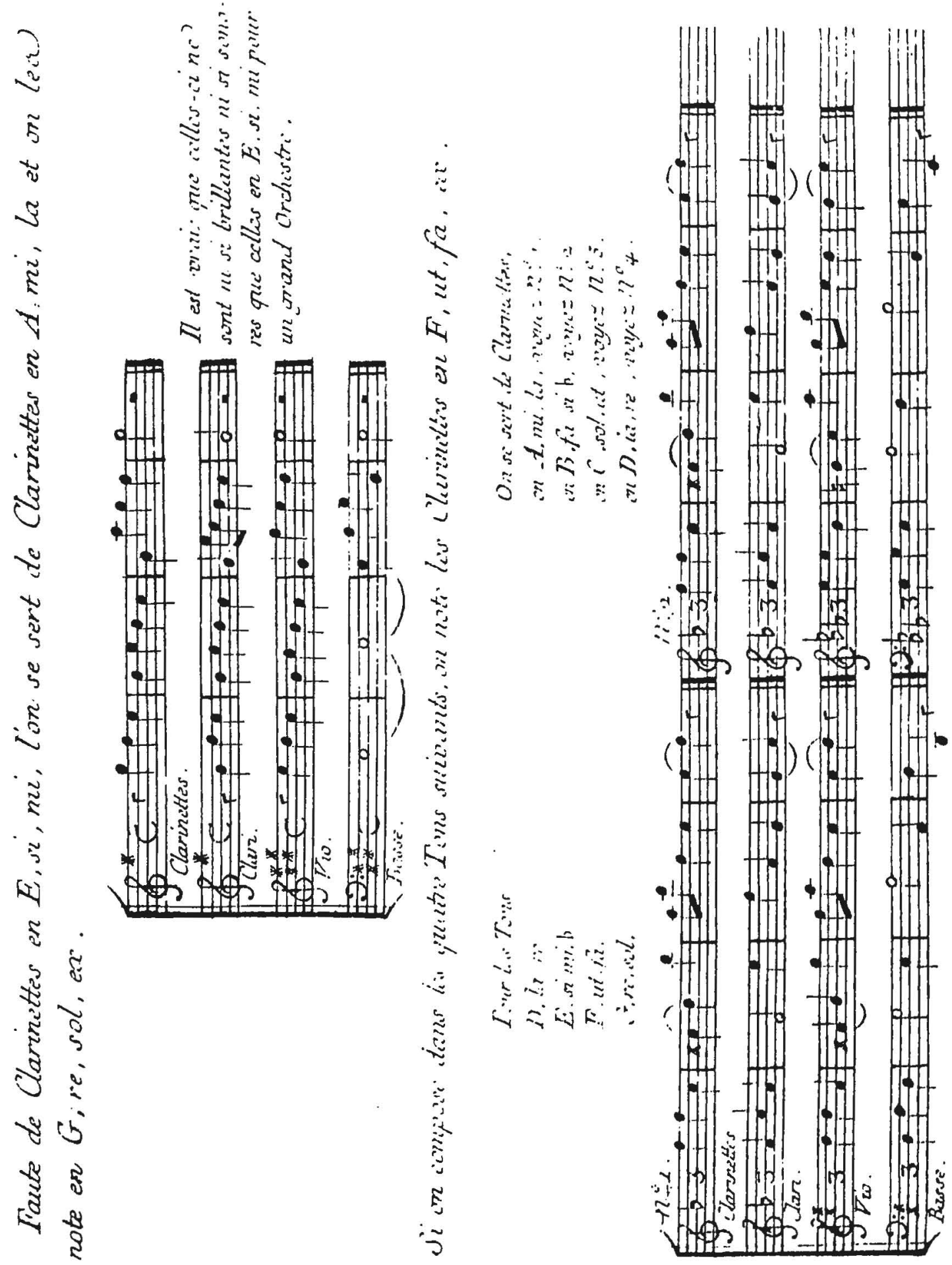


Because of a scarcity of clarinets in $\pi$, one would use clarinets in $A$, and one would notate it in $G$, ex.,

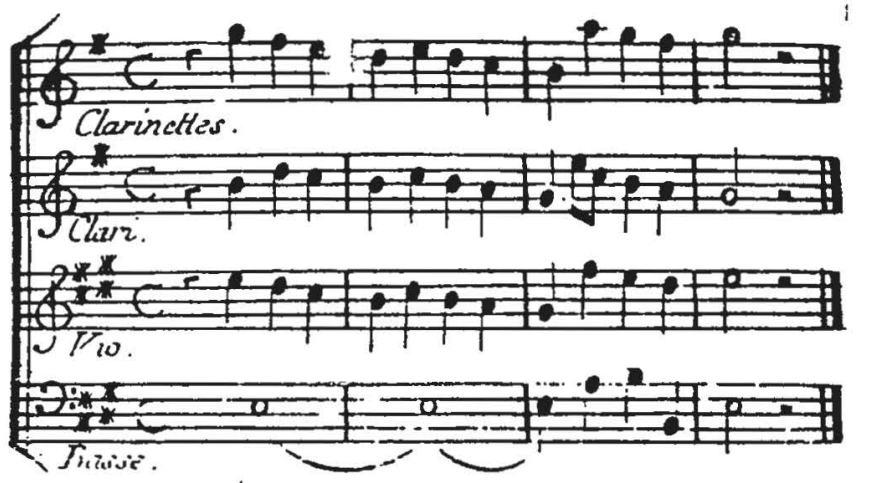

It is true that these are neither as brilliant nor as sonorous as those in $\mathrm{E}$ with regard to a large orchestra.

If one composes in the following four keys, one notates clarinets in $F$, ex.,

$$
\begin{array}{ll}
\text { For the lreys, } & \text { One would use the clarinets, } \\
\text { D, } & \text { in A, see no. } 1 . \\
\text { E-flat, } & \text { in B-flat, see no. 2. } \\
\text { F, } & \text { in C, see no. } 3 . \\
\text { G, } & \text { in D, see no. } 4 .
\end{array}
$$

(See examples pages 105, 107).

One sees, therefore, by this index of examples, that one is able to use clarinets in $D$ as well as in $A$ for the key of $D$. The difference being that those in $D$ are much more brilliant and more sonorous than those in $A$; and it is necessary to notate the first in $C$ and the others in $F$, as I have indicated.

If one composes in A minor one would use the clarinets in $D$, and write it down in G minor, ex.

(See example page 107). 


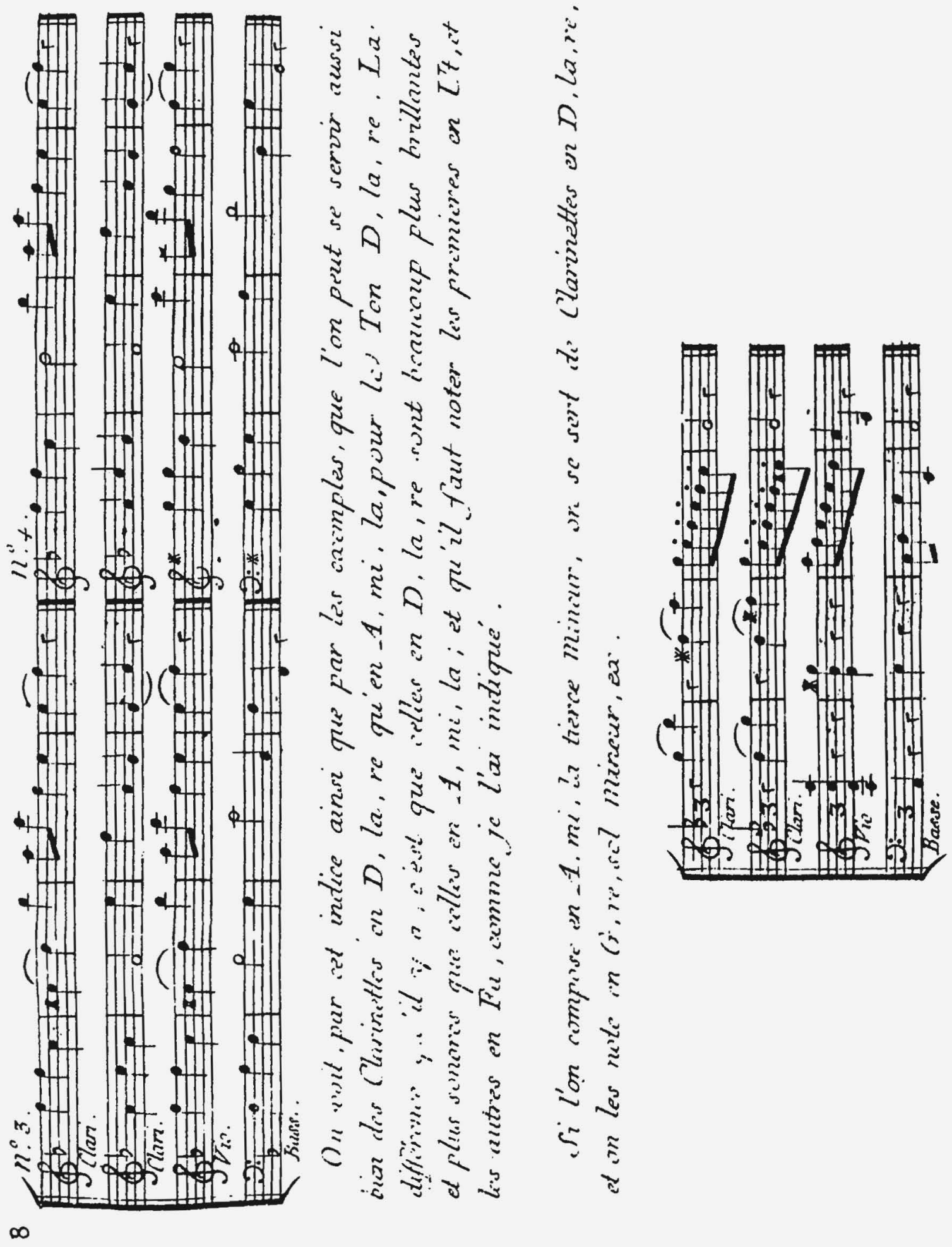


$a$




If one composes in the three corresronding minor keys one notates the clarinets in the key of $D$ minor, ex.

$$
\begin{array}{ll}
\text { For the keys, } & \text { One uses the clarinets, } \\
3 \text { minor, } & \text { in } \therefore \text {, see no. } 1 . \\
\text { C minor, } & \text { in } 3 \text {-flat, see no. } 2 . \\
\text { D minor, } & \text { in C, see no. } 3 .
\end{array}
$$

(See examples page 108).

If one composes in $E$ minor one would use the clarinets in $\Lambda$, notating in $G$ minor, ex.

(See example page 108).

If one composes in $F$ minor one must use the clarinets in B-flat, notating in G minor, see no. 1 .

If one composes in G minor one must use the clarinets in C, notating in G minor, see no. 2 .

(See examples page 110).

$$
\text { pt. } 9 .
$$

The composer should also be careful to mark the kinds of clarinets at the beginning of each piece. This is applied equally to the hunting horns. 
Si lon Compose en $F$, ut, fa, tierce mineure un se sert de Chrinettes on $B$, fia, si $b$, en les noteunt in (F, ie. sol. mineur, voyes $n: 1$.

Si l'on Compose on $G$, re, sol tierce mineure on se sert de Clarinettes en $C$, sol, ut, en les nitant in (i, ,e sol mincur, rayez $n^{0}: a$.

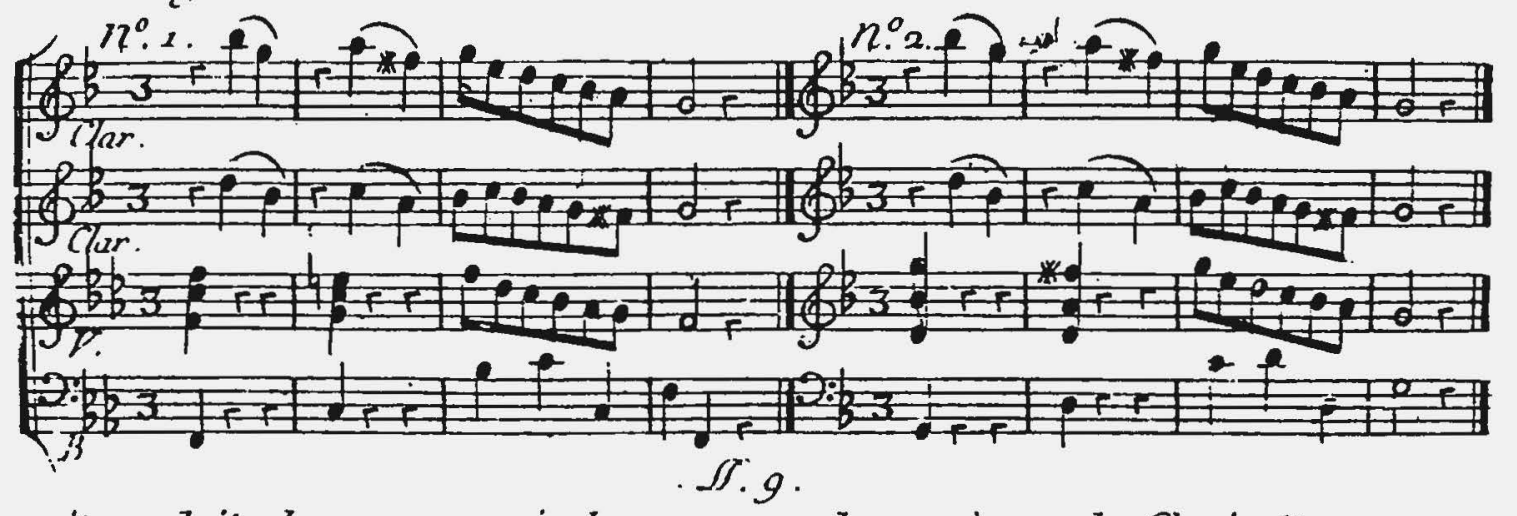


de ihutue Piece. Ce qui se fäit éculement pour les Corir de Chasise.

$$
\text { dr. } 10 \text {. }
$$



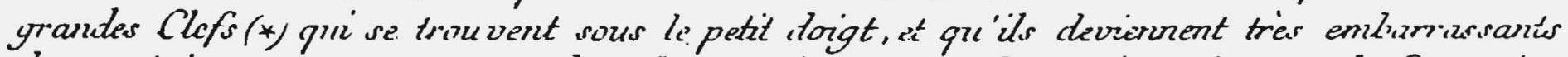
dans cortains passages, no tonct dans la grande nitasse, il est nécersuive que le Compositaur

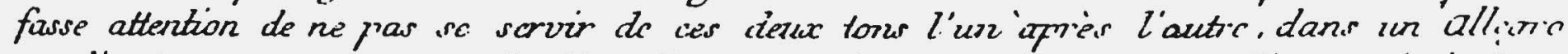
ou d'auties morenenienter semblables. Par ecomple, les passager que l'on ivoit iz lii, Lettie laf ne peuvení jumair être executér dans ce mounconent, ni ceux de la Lrttrc (b.)

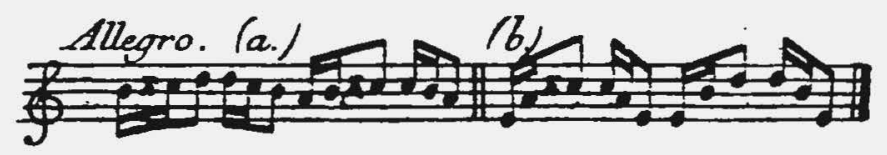

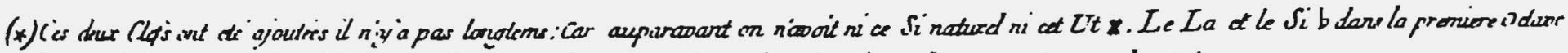

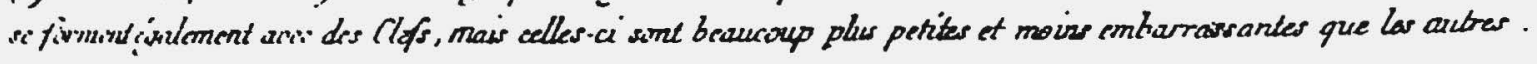




$$
\text { pt. } 10 \text {. }
$$

Since the $B$ natural in the first octave [b] and the C-sharp in the second [C\#] are made with the two large keys, * which are found under the small finger, and these can be very cumbersome in certain passages, especially the very fast ones; it is necessary that the composer pays attention that he is careful not to use these two notes one after another, in an Allegro or other similar movement. For example, the passages that one sees at letter (a) would never be able to be executed in this manner, nor that at letter (b).

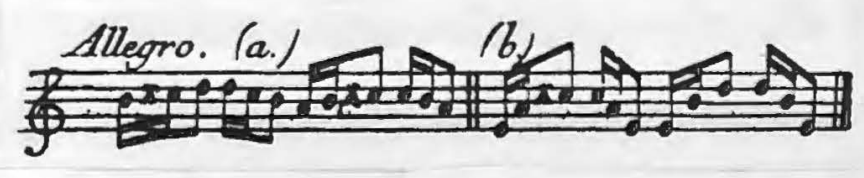

(*) These two keys were added not long ago, because before one had neither the B-natural or the C-sharp. The A and the B-flat in the first octave $\left[a^{\prime}, b^{b}\right]$ are formed equally with the keys, but these are much smaller and less encumbering than the others. But when one ascends or when one descends without leaps especially in a slow movement, it is much more practicable, for ex.

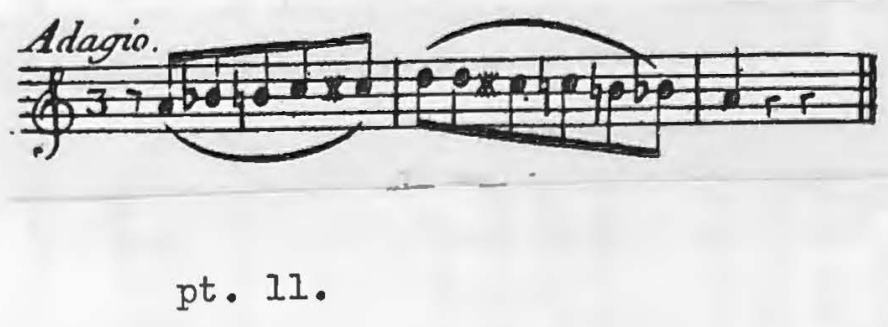

One finds also some figures or passages which cannot be executed with connected notes or slurs. Here are some of them. 
Mais quand on monte ou que lon descerut sans intrivalles, sur tout dans un monuremint l.net, ils sont beaucoup plus praticiahles, par eix.

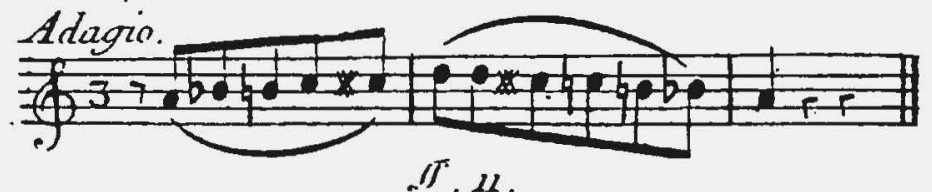

IT. 11.

Il se trowve aussi des Traits ou Passages avec Liaison ou Coulés que l'on ne prut civéruter. En noici queligues uns.

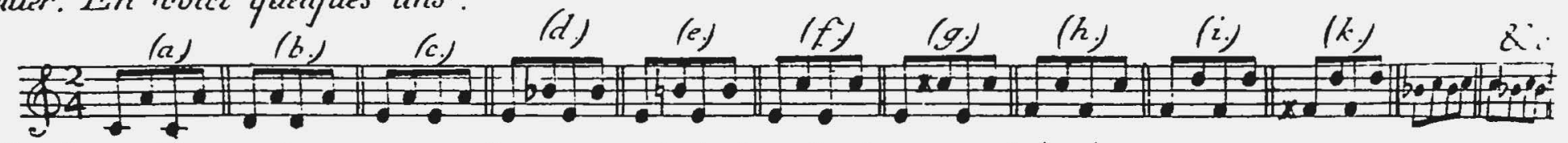



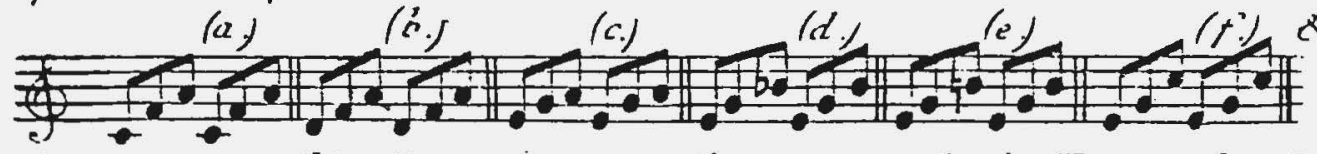

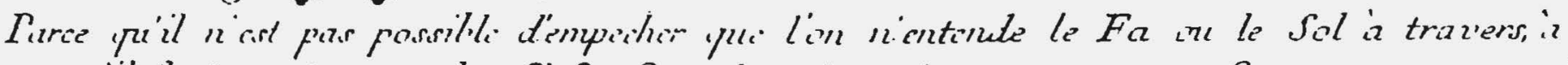

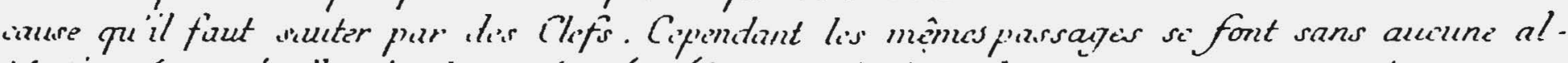

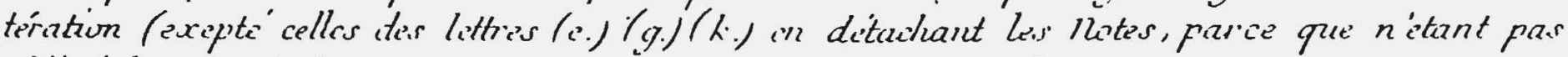

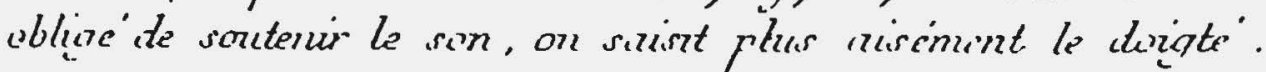

$$
\text { IS. } 1: \therefore \text {. }
$$

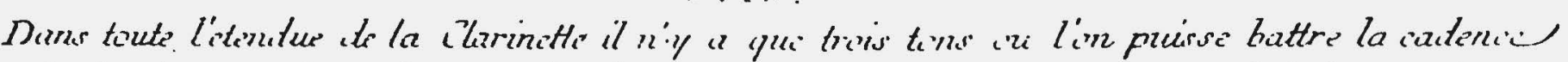



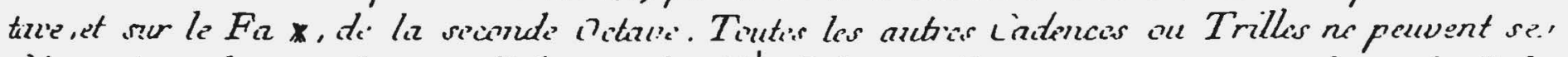



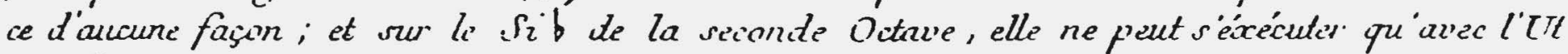
* on la secicrude iruperflue.

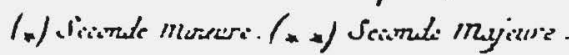




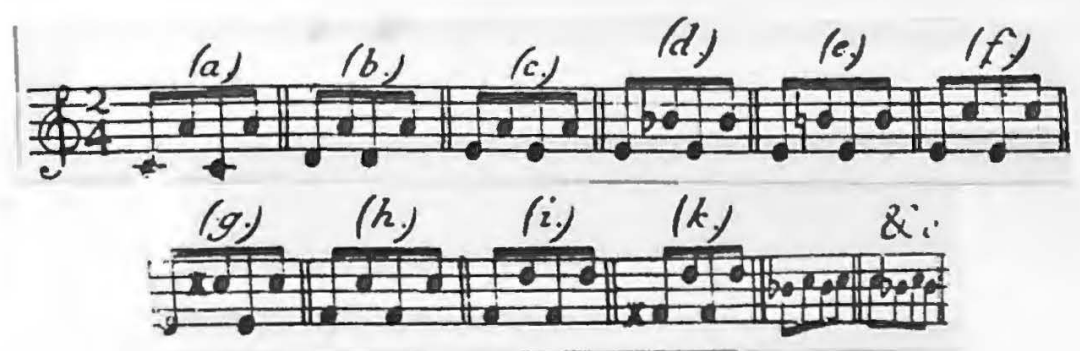

The effect that they produce when one wants them slurred is this.

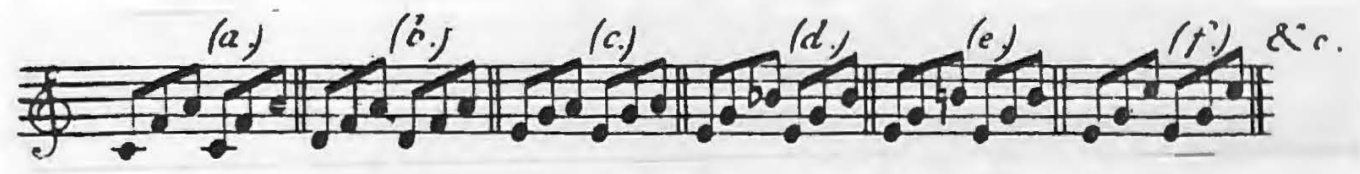

As it is not possible to keep from hearing the ' $F$ or $G$ which lie in between, it is necessary to leap [over them] by means of the keys. Nevertheless, the same passages are played without any alteration (except those of letters $c, g$ and $k$ ) by detaching the notes. Since it is not necessary to sustain the tone, one can achieve the fingering more easily.

$$
\text { pt. } 12 \text {. }
$$

Throughout the complete range of the clarinet there are only three notes where one can trill on the half step or the small second, * for ex.; on the A, and B-natural of the first octave $\left[a^{\prime}, b^{\prime}\right]$ and on the F-sharp of the second octave $\left[f^{\prime}\right]$. All the other cadences or trills are only able to be made with the large second.** On the B-flat of the first ocrave $\left[b^{b}\right]$, it can only be executed with the C-sharp [C\#' $]$ or the augumented second.

* minor second. ** major second. 
Beaucoup de drubles Croches tans le mode parallele ne sonf print en usage sor In Clari. nette, attentu que la Poitrine doit substikuer au conp de Langue, a cruse de la porition ds. l'anche qui se trowe sous le Palais de la Bouche. IExample suivant montrera de quelle fas'on on doit mettre les parties de Clarinettes quand le Violon fait des doubles Croches.



$$
\text { T. } 14 .
$$

J'aurois bien d'auties choses à dise relativement a cet Instrument, mais je me suir contenti' d'en donner les regles les plus nécessaires. criaignant de rendre ce petit Ouvrage trop obscur et d'embrowiller lo Lecteur. La Riggle la plus sure et la moil. leure de Composer pour la. Clarinette, c'est d'avoir pour but un Chant agréable et naturel, d'éviter les grands sauts ct les Traits trop Chromatiques. En fin dej suive la regle generale qra' dit i qu'il faut Composer ou Chanter pour le Cour et l'Oreille; il faut toucher at ne pas étonner \& $\mathbb{C}_{c}$. Les Pièves que je donnerai à la fin, du Livre pourrint peut ître sernir d'eccemple de ce que je viens de dired.

\section{Fin de la Premiere Partie.}




$$
\text { pt. } 13 .
$$

Many of the repeated sixteenth notes are not at all in use on the clarinet since the lungs must substitute for the stroke of the tongue, on account of the position of the reed, that is found under the roof of the mouth. The following example will point out in what manner one must use the parts of the clarinets when the violin plays sixteenth notes.



I could very well have said other things relating to this instrument, but I have been satisfied to give the most necessary rules concerning it; fearing to render this small work too obscure and confusing to the reader. The safest and preferable rule for composers for the clarinet is to have for their goal a natural and pleasing melody, to avoid great leaps and overly chromatic figures. In conclusion, to follow the general rule which says: it is necessary to compose or to sing for the heart and the ear; it is necessary to move not astonish, etc. The pieces that will be given at the end of the book should be able to serve as an example of that which I have spoken about. 
CHAPTER IV

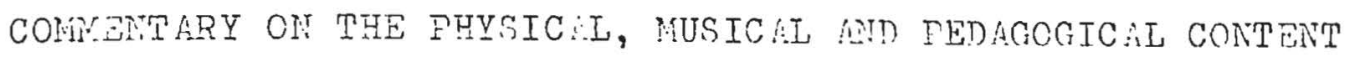
OF THE ESSAI D'INSTRUCTION

There are two extant copies of Roeser's Essai. One at the Bibliotheque Royale de Belgique, ${ }^{1}$ the other at the University of Nichigan. According to Nacdonald, the latter must have been issued after 1783 .

The date has been determined by inclusion of a Boyer catalogue which predates Johansson facsimile 90 (1784?). The issue may have changed hands or may have been initially sold as early as 1790 or as late as 1802 . The conclusion results from noting that a label which reads "chez Mercier, à la Musique Royale, Rue des Prouvaire, près la Rue St. Honoré, No. $33 "$ is pasted over the original imprint on the title page of the Michifan treatise. Hopkinson, 91 assigns the dates 1790 to 1802 for this address of Mercier. ${ }^{2}$

Consequently, the Minkoff Reprint edition, on which the translation is based, must have been reprinted from the University

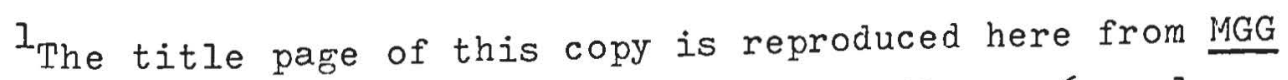
(1957), s.v. "Instrumentation," by Ludwig K. Mayer, 6: cols. $1261-1262$.

2 Robert James Macdonald, "Frangois-Joseph Gossec and French Instrumental Music in the Second half of the 18th century," 2 vols. (Ph. D. dissertation, University of Michigan, 1968), 1: 169. 


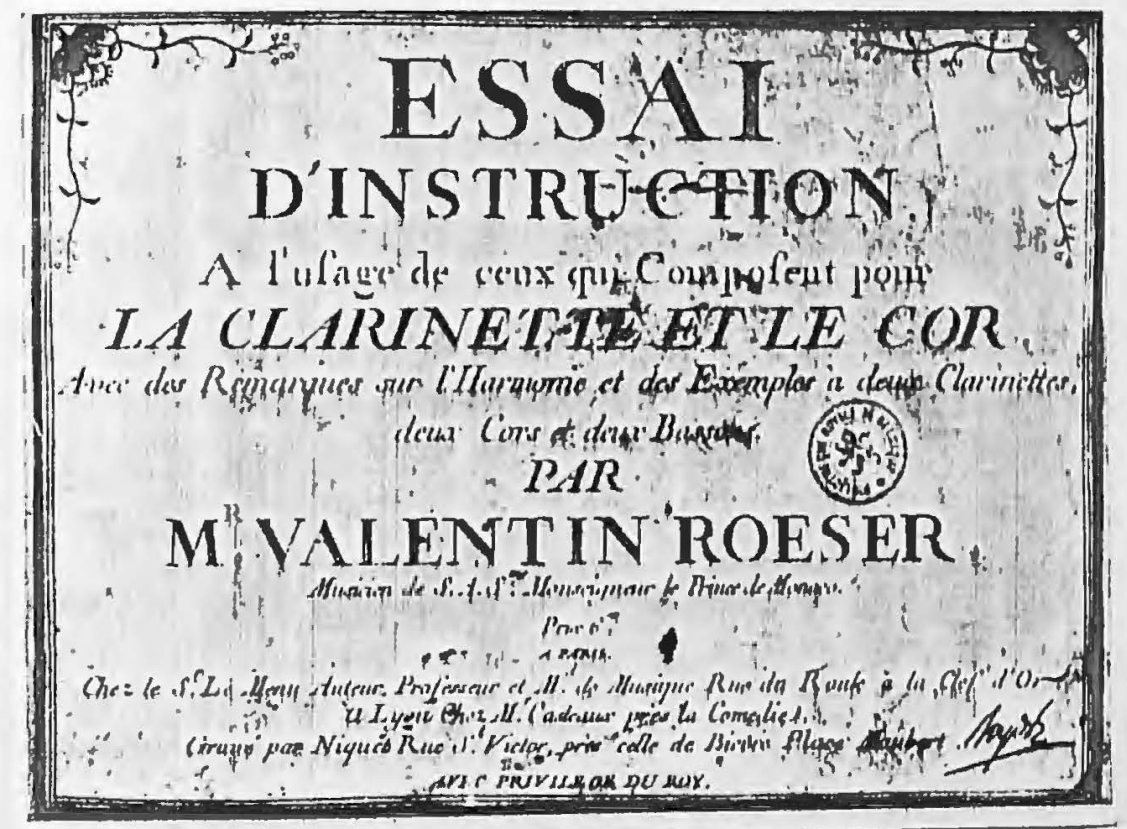

The title page of the 1764 edition of the Essai d'Instruction from MGG (1957), s.v. "Instrumentation," by Ludwig K. Mayer, 6: cols. 1261-1262. 
of Yichigan copy. The title pace gives the identical address of lercier as above, where the title page of the Brussels cony indicates Le Venu as the publisher. is Soyer catalog is also included in this edition indicating Boyer's address as, "Rue neuve des petite Champs, près la Rue Gaillon, Maison de l'Apoticaire, ĩo. 83". From about 1776 to Nay of 1783, Nme Boyer and He Menu published music together at "rue de Roule à la Clef d'or". After May of 1783, M. Boyer replaced Mme Boyer in this partnership. His address of "rue Neuve des Fetits-Champs, près celle de Gaillon, No. 83" was printed on the title pages of music with Mme Le lenu's address. M. Boyer also published works by himself at his own address. From an advertisement in the Mercure de France (I January 1785) Boyer's address is seen to have changed to "rue de Richelieu, à la Clef d'or, à l'ancien Café de Foy". By 22 fugust 1790, líme Le Menu's business was taken over by Lobry. Boyer continued to publish at his last address until 24 December 1796, when he was succeeded by Naderman. ${ }^{3}$ This information explains why a Boyer catalog of c. 1784 was included in a publication that was originally printed by Le Menu. We can only assume that Mercier acquired a copy of the Essai sometime between 1790 and 1802.4

${ }^{3}$ See, Cari Johannson, French Music Fublishers' catalorues of the Second Half of the Eighteenth Century, 2 vols. (Stockholm: Almquist \&. Wiksells, 1955), 2: 104-107.

${ }^{4}$ See, Cecil Hopkinson, A Dictionary of Parisian líusic Publishers, 1700-1950 (London: the author, 1954), 91. 
In concluding his description of the clarinet, La Borde (1780) recommends Roeser's Essai as well as Francoeur's Diapason général (1772).

On peut consulter la méthode de $\because$. Rodser, Maître de Clarinet, qui a développé, avec beaucoup de précision la maniere d'en jouer, $\therefore$ le Livre des Unissons de $M$. Francoeur le Neveu. 5

One must consult the method of $M$. Roeser, Maître de Clarinet, who has developed, with much precision the manner of playing, and the book of unisons by M. Francoeur the younger.

Forkel $(1792)^{6}$ and Choron et Fayolle $(1810-11)^{7}$ both give 1781 as the publication date of Roeser's Essai. This may indicate that the Essai was popular enough to be reprinted in 1781. It also appeared in Le Menu's catalog of 1765 through Boyer's catlog of $1788 .^{8}$

${ }^{5}$ [Jean-Benjamin de La Borde], Essai sur la musique ancienne et moderne, 4 vols. (Paris: Ph. D. Pierres, 1780), I: 252.

${ }^{6}$ Johann Nicolaus Forkel, Allegemeine litteratur der Musik (Leipzig: Nachdruck der Ausgabe, 1792, reprint ed., Hildesheim: Olms, 1962), 444.

7 Alexandre E. Choran et F.J.M. Fayolle, Dictionnaire historique des musiciens, artistes et amateurs, morts ou vivans (Paris: Valade, 1810-11, reprint ed., 2 vols., Hildesheim: Olms, 1971), 2 : 230-231.

8 Johansson, French Music Publishers' catalogues, 1: facsimiles 80-99. 
Part one: the types of clarinets that are used

Roeser initially compared the clarinet to the oboe and transverse flute, presumably because these instruments were already quite popular, and because several didactic tutors were available in France, e.g.; Freillon-Poncein (1700), Hotteterre (1707, 1713, 1719-1722, c. 1728, 1741), Schickhard (c. 1720), Corrette (c. 1735), Quantz (1752), Bordet (c. 1755), kahaut (c. 1759) and Delusse (c. 1761).9 Roeser appears to make the earliest known specific reference to clarinets in various pitches in this part, by giving seven types. Majer (1732, 1741) and Eisel (1738) in their general treatises, make no mention of the pitch of the clarinet. De Garsault spoke of his clarinet, in Notionaire (1761), as being pitched in the key of F, but also suggested the use of clarinets in other pitches Without specifically naming them (see, page 59). Francoeur, whose Diapason Eénéral is based largely on Roeser's work, mentions all seven types and adds the b-natural clarinet to his list. He later mentions that this instrument is actually the B-flat instrument, which one changes by using another "corps", or middle joint. 10 La Borde in his Essai surpasses Roeser and

9 For information on these tutors see, Thomas Warner, An annotated Bibliography of Woodwind Instruction Books, 1600-18,30 (Detroit: Information Coordinators, 1967).

10 [Louis-Joseph] Francoeur, Diapason général de tous les instruments à vent (Paris: Des Lauriers, 1772, reprint ed., Genève: Minkoff Reprint, 1972), 21, 24. 
Francoeur by naming all of these types and adding a clarinet pitched in e-flat. Il It should be mentioned that the practising clarinettist was not able to carry around all of these instruments, or even the equivalent in pièces de rechange. Undoubtedly, these instruments were listed in Roeser's Essai for the convienience of the composer, as well as for general information.

Fart two: the types of clarinets most often used and the tone quality of different clarinets

Clarinets pitched in A, B-flat, $C$ and $D$ were the most often used according to Roeser. Francoeur agreed and considered them "Ies Clarinettes les plus favorables". 1? Where Roeser's C clarinet is the sweetest type, Francoeur adds that its sound is sad and lugubrious, suitable for somber effects and funeral pieces. 13 Likewise, his E clarinet is very high like Roeser's; and used with storms, battles and tambourines. ${ }^{14}$ In part eight, Roeser mentions that his A clarinet is neither as brilliant or as sonorous as the Eclarinet. Francoeur's A clarinet has a visorous sound, sweet but less somber than the G clarinet. It is suitable

11 [La Borde], Essai sur la musique, 1: 250.

12 Francoeur, Diapason général, 21.

${ }^{13}$ Ibid., 23.

${ }^{14}$ Ibid., 25. 
for tender and gracious airs. 15

An anonymous French tutor of about the same time as Francoeur's treatise states, that the most often used clarinets are pitched in A, B-flat and natural, C and D. Furthermore, "with these four clarinets one can execute all music written for this instrument". 16 The B-flat instrument was naturally provided with a pièce de rechange to change to 3 natural. A performers' viewpoint seems to appear in F.D. Castillon's long article on the clarinet appearing in the 1776 edition of the Encyclopédie. 17 He states specifically that the tonality of the clarinet is in A, but also observed that it is now provided with duplicate middle joints in order to play in the key of B-flat. This preference for the mellow sound of the clarinet pitched in A is a significant change, in contrast to the shrill, hard sound of de Garsault's E clarinet of 1761. Castillon's text is directed to the performer rather than the composer, even a fingering chart for a four-key clarinet is provided. An illustration of this clarinet (plate

${ }^{15}$ Ibid., 23

${ }^{16}$ Principes de Clarinette avec la Tablature des Meilleurs Maitres (Paris: n.p., c. 1772), see, Daniel Thomas Bogart, "A History of the Clarinet as an Orchestral Instrument from Inception to Full Acceptance into the Hoodwind Choir," (Ph. D. dissertation, Michigan State University, 1968), 23-25.

17 Encyclopédie... Supplement (Amsterdam: M.M. Rey, 1776), vol. 19, tome II, 450-451, see, Eric Halfpenny, "Castillon on the Clarinet," Music and Letters 35, no. 4 (October 1954): 332-338. 
twenty) appears in the "Lutherie" plates of the suite de Recueil de Flarches (1777) of the Encyclopedie. It clearly shows the front of the clarinet in figure 17, its back with the joints serarated in ficure 18, and the mouthpiece with its attached barrel. Youthpiece and barrel are shown with its reed detached from it in figures 19 and 20. The numbers of the tone holes refer to the fingering chart provided in the text of the article on the clarinet. This instrument is without doubt, the clarinet that Roeser described in his treatise.

Vanderhagen's extensive and important Méthode (c. 1785) does not mention the types of clarinets specifically that were used. However, he does include clarinets in A, B-flat, B-natural, $C$ and $D$ in his examples of transposition. ${ }^{1}$ there are four anonymous Inglish clarinet tutors during the eighteenth century (see, Appendix C for their titles). The earliest of these, The Clarinet Instructor (c. 1780), evidently served as a model for the remaining books. 19 Its author specifies only clarinets

18 Amand Vanderhagen, Méthode Nouvelle et Raisonnée pour la Clarinette (Paris: Boyer et Le Menu, c. 1785, reprint ed., Geneve: Minkoff Reprint, 1972, bound with Roeser's Essai), 1718. This reprint edition is erroneously dated as 1798, its correct dating is determined by an advertisement in the Mercure de France, see, Warner, 39.

${ }^{19}$ See, Eugene E. Rousseau, "Clarinet Instructional llaterials from 1732 to CA. 1825" (Fh. D. dissertation, State University of Iowa, 1962), 26-27, 31-33, cf. Warner, 34, 38, 47. 
PIATE 20
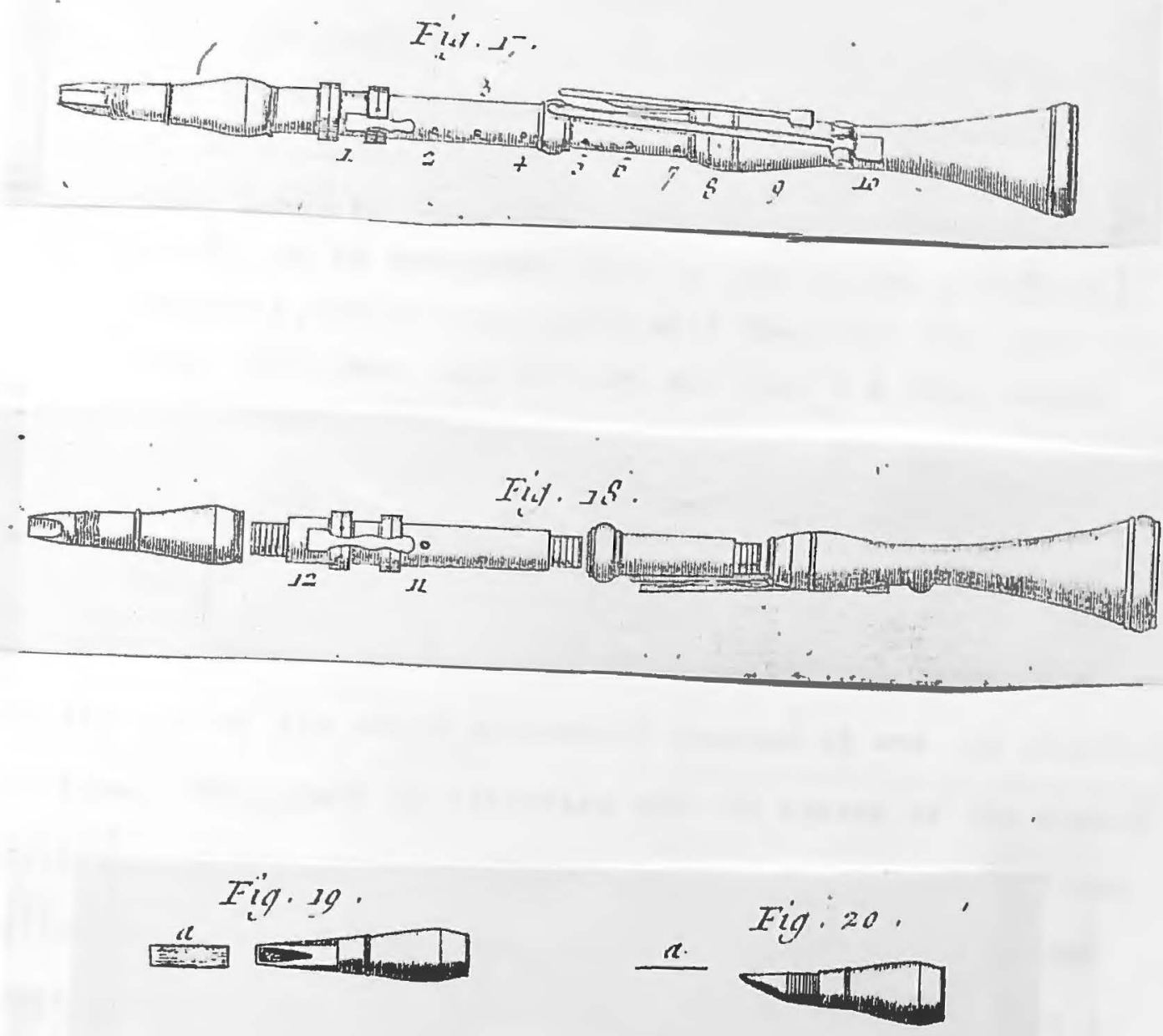

A four-key clarinet from the Encyclopédie... Suite de Recueil de Planches (Paris: Panckouche, Stoupe, Brunet, 1777), 143, supplemental plate 4 . 
pitched in $C$ and $B-f l a t$ on a page concerning transposition. 20 A similar passage occurring in the Compleat Instuctions [sic] for the Clarinet $(c .1785)$ is clearer in its meaning:

The only Keys in which Clarinet viusic is printed are $C$ and $F$, for which a C Clarinet must be used: But as This Instrument is often required to Ilay in concert with Bassoons and other Instruments, in the Key of $B^{b}$ or $\mathrm{E}^{\mathrm{b}}$, it is necessary in this case to use a $\mathrm{B}$ [flat] clarinet, which will agree with them tho' the parts for this Instrument are written and play'd a Note higher than those of the other Instruments. 21

Part three: the range of the clarinet

Roeser states the range of the clarinet as being three octaves from $f$ to f'''. He purposely put the lowest note, e, at the end of the range presumably because it was not playable in tune. This fact is clarified when he speaks of the recent addition of the third and fourth keys, for the notes b'' and c''-sharp, in part ten. In part four, Roeser mentions that further semitones could have been shown in his range, but as

20 The Clarinet Instructor by which playing on that Instrument is rendered easy (London: Longman \& Broderip, c. 1780), 7. Rousseau, 112, cites this passage and mistakenly refers to $B-f l a t$ and E-flat clarinets. The reference is actually made to a B-flat clarinet that is used in the keys of E-flat or B-flat, and a C clarinet used in the keys of $F$ or $C$.

${ }^{21}$ Compleat Instuctions [sic] for the Clarinet (London: 3 . A. \& D. Thompson, c. 1785), 8. 
these notes were badly out of tune, he decided to leave them out. in incomnlete method in the Paris conservatory, dated c. 1765 by Rousseau, provides a fingering chart for the four-key clarinet, that adds three semitones to this range ( $f-s h a r p, b-n a t u r a l$, and $g^{\prime}-$ sharp) and extends it to $g^{\prime \prime}$ '.2? Another fingering chart, for the four-key clarinet, identical to this one is found in Jacques Potteterre's Méthode Dour apprendre à jouer en peu de tems de la flûte (Paris: Bailleux, c. 1765).23 Castillon, in the Encyclooédie, follows these fingering charts in their ranpes but provides some significant differences in fingerings. 24 Francoeur added two semitones to Roeser's range (b-natural and $\mathrm{g}^{\prime}-$ sharp) as well as extending it two more notes to a''1.25 The anonymous Frincipes de Clarinette follows Francoeur in its range of from e to $a^{\prime \prime}$, and includes the three semitones of the incomplete method. 26 This is the last known fingering chart for a four-key clarinet.

Francoeur also provides a division of his overall range into two parts, "Premier" and "Second Dessus", for all the types of clarinets. He explains that some people are not able to play the

22 See, Rousseau, 25, 26, 63.

23 Rousseau, 105, see, Warner, 9.

24 See, Halfpenny, 337-338.

25 Francoeur, 18.

${ }^{26}$ See, Bogart, $24-25$. 
lowest notes as well as the highest notes of the range.? IIis "Fremiere Clarinette" extends from a to fll, "Second Clarinette" from $f$ to $c^{\prime \prime}$ and $e$ to d''. The individual ranges of each clarinet that he mentions all fall within these boundaries. ${ }^{28}$

Vanderhagen also used a range of from e to a'l' in his two charts provided for a five-key clarinet. The first chart exhibits a range of from e to a'' without any accidentals, and is called, "Gamme Naturelle" (See, plate twenty one for this chart). The second chart, "Gamme Diesée et Bemolisée", provides fingerinģs for the remaining sharps and flats of the range, from f-sharp to e'''flat. 29 The English tutors of the eighteenth century are more conservative in their charts, providing a range of from e only to f''. However, Vandenbrock in his instrumentation treatise of 1793, indicates the highest pitch of the clarinet as an $e^{\prime \prime \prime}$ wi.th the notation "et plus" written below it. He also recommends not writing above $c^{\prime \prime}$ since it is difficult to play from $c^{\prime \prime}$ to $e^{\prime \prime} \cdot 30$

27 Francoeur, 22.

28 It was demonstrated by Becker that as early as 1765, Franz Pokorny used the range of Francoeur's "Premiere Clarinette" in his clarinet concerto in E-flat major, and the range of the "seconde Clarinette" for his concerto in B-flat major. See, EDP, vol. 4l, "Klarinetten-Konzerte des 18. Jahrhunderts," ed. by Heinz Becker (Niesbaden: Breitkopf \& Hurtel, 1957), x.

${ }^{29}$ Vanderhagen, $[i, i i]$.

30 Othon Vandenbrock, Traité général de tous les instrumens à vent (Paris: Boyer, 1793), 40, 44, cf. Rousseau, 79. 
FIPT: 21
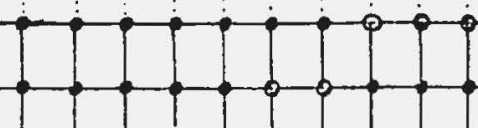

(1)
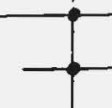



今ั.

5

Mi

Mi b


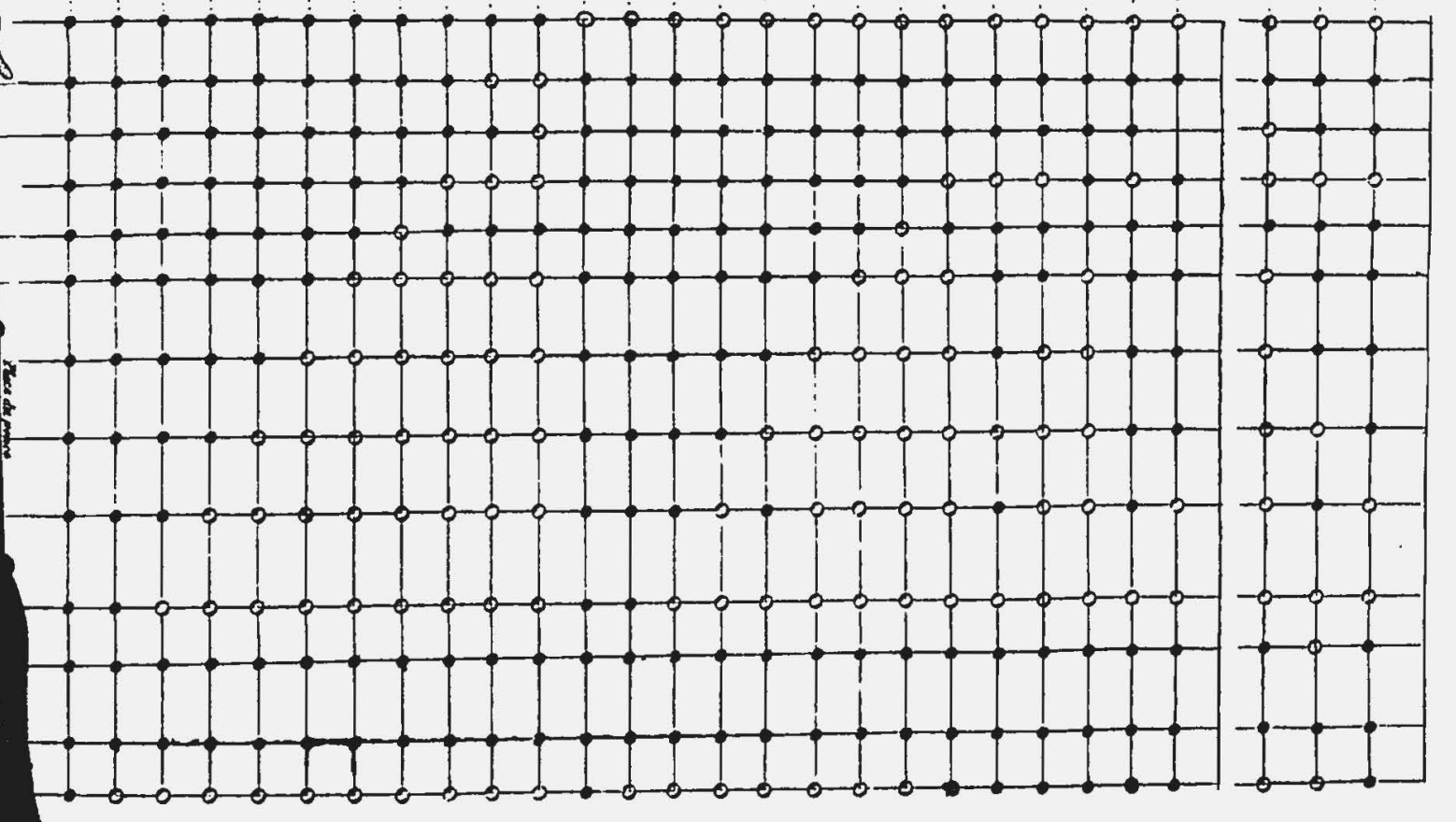



A fingering chart for the five-key clarinet from Amand Vanderhagen, Methode Nouvelle et Raisonnée pour la Clarinette (Paris: Boyer et Le Kienu, c. 1785, reprint ed., Genève: Minkoff Reprint, 1972), 2 . 
Part four: the types of sound within the range of the clarinet

As early as 1726, Weigle recognized the high and low ranges that are characteristic of the clarinet, in his Musicalisches Theatrum (see, page 46). He did not refer to the contrast in quality that these registers possess, but subsequent writers refer to this contrast in ensuing decades. Adlung's brief mention in his Anleitung (1758) noted only two different kinds of quality: "In der Tiefe lautet es ariders als in der Hbhe, und alsdenn nennt man es chalumeau". 31 Roeser is the first writer to describe the three basic sound qualities within the range of the clarinet, and to label them as chalumeau, clarion or clarinet, and high or acute (aigus). He is followed in this description by Francoeur and La Borde in the eighteenth century. Francoeur adds that the "Clarinettes tons" comprise the range that is used the most. 32

The more conservative English viewpoint on the sound quality of the clarinet appears only in John Callcott's article, "Clarinett", from his unfinished Dictionary of Music (1797-1807). 33

All other wind instruments form their octave to their lower notes by the same fingering with a force of breath; but the clarinett is so contrived that by keepine down the upper key behind the Instrument all the notes become a

${ }^{31}$ Jacob fidlung, fnleitung zu der musikalischen Gelahrtheit (Erfurt: J.D. Jungnicol, 1758, facsimile ed., ed. by Hans Joachim Koser, Kassel und Basel: Bärenreiter, 1953), 588.

32 Francoeur, 18.

${ }^{33}$ London, British Library, Add. 27680. 
Twelfth or Double fifth higher.

This alteration affects the tone of the notes $:$ constitutes two different parts of the instrument. The lower called chalumeau, being similar to species of an old plute if termed, 34 the higher called Clarinett, a diminutive of Clarino, signifying a little Trumpet being the next powerful instrument used in military service.

Callcott uses the terms of the Frenchmen but simply ignores the highest register of the clarinet. It should be mentioned that this is the first English source that speaks of the chalumeau as "beinE similar to species of an old Flute". Numerous subsequent nineteenth and twentieth century tutors and treatises were to use the same terminology and description, of the range of the clarinet, that is found in Roeser's treatise.

Part five and six: tables of unisons demonstrating transposition and an explanation of transposition

This method of demonstrating the transposition of various clarinets in unison with string instruments was successfully copied for all the instruments in Francoeur's and Vandenbrock's treatises. It was subsequently used by Berlioz and many others

34 Here, Callcott might be considering the eighteenth century practise of using the term "chal" or "chalumeau" over notes in clarinet parts, indicating that these sections were to be played an octave lower. "Clar" or "clarinette" was used to indicate that the passage was to be played an octave higher. See, Rousseau, 7475 . 
through the twentieth century. 35

\section{Part seven: the most favorable keys on the clarinet}

Roeser includes both the major keys of $F$ and $C$ and the minor keys of $D$ and $G$ as the most favorable keys. Francoeur mentions only $F$ and $C$ major but states that with the four clarinets in $A, B$-flat and natural, $C$ and $D$, it is possible to play in all keys. ${ }^{36}$ an identical statement is also made in the Princires de Clarinette (c. 1772). 37 La Borde follows Roeser in stating the most favorable keys as $F$ and $C$ major and $D$ and $G$ minor. 38 The English tutors all state that the B-flat clarinet is used for the keys of B-flat and E-flat, and the C clarinet is used for the keys of $\mathrm{C}$ and $\mathrm{F}$. No minor keys are mentioned. Interestingly, Roeser notes here that the $D$ clarinet must be excused for $D$ minor, because it is too small to have a large key to play c''-sharp. Without the c''-sharp key the D clarinet would only have been a three-key instrument, and not very easy to play in the newest style of music. The addition of keys is

35 Rousseau, 113, mistakenly calls Roeser's "clarinette en E, si, mi" a B-natural clarinet. He identified it with the clarinet in mi, a nineteenth century name of the B-natural clarinet. The transposition given by Roeser proves that this instrument is pitched in high $\mathrm{E}$.

$$
\begin{aligned}
& 36 \text { Francoeur, 22, } 21 . \\
& 37_{\text {See, Bogart, } 25 .} \\
& 38_{\text {La Borde, } 251-252 .}
\end{aligned}
$$


also discussed in part ten.

Fart eight: indexes and examples of transposition of all the clarinets

Here are further examples of the most useful method of demonstrating transposition, used by most subsequent writers. Part nine: marking the kind of clarinet to be used in the score

A. direction to the composer not always included in other eighteenth century treatises.

\section{Part ten: the four keys of the clarinet}

Roeser makes the first reference to the $b^{\prime}$ and $c^{\prime}-$ sharp keys by stating. "These two keys were added not long ago because before one had neither the B-natural or the C-sharp". The low e that was gained by the addition of the b' key was probably badly out of tune on these four-key instruments. Thus, Roeser set this note outside his range. Credit for the addition of these leys as well as the fifth key, was given to the Brunswick organ builder, Barthold Fritz (1697-1766), initially by Lefevre in his Méthode (1802). 39 Lefevre states that the third key was added some time before the fourth and fifth key were added together. This is in contradiction to Roeser's interpretation, which associates the third and fourth keys together. Roeser's statement must be accepted as being more accurate since he lived

39 Jean-Xavier Lefevre, Nêthode de clarinette (Paris: Imprinerie du Conservatoire, 1802), 2. 
at the same time the keys were added ${ }^{40}$ (see, pages $73-74$ ).

He also cited two passares that are impossible to play on the four-key clarinet, and admonishes the composer to use the $b^{\prime}$ and $c^{\prime}$ '-sharp in a slow movement without leaps. Francoeur provides his own examples of the same technical difficulty of playing $b^{\prime}$ and $c^{\prime \prime-s h a r p . ~}{ }^{41}$ Subsequent instrumentation treatiscs use examples to illustrate technically difficult or impossible passames. Castillon only casually mentioned the difficulty of some fingerings on the clarinet in his article in the Encyclopédie. However, at the conclusion of his article he stated that "At the time of writing, there is in Berlin a musician who plays a clarinet with six keys, on which he obtains all the modes. It has already been shown that four keys cause difficulties. How much worse it must be with six!"42 vithin a few years, most clarinets in France, Germany and England were either of the five or six-key type.

Part eleven: passages that cannot be played as slurred notes

Roeser makes the point that almost all of these examples can be played detached without hearing a note in between the original eighth notes. This type of practical comment does not

40 See, Robert Austin Titus, "The solo music for the clarinet in the eighteenth century! ( $\mathrm{Ph}$. D. dissertation, State University of Iowa, 1962), 35-36.

${ }^{41}$ Francoeur, 35 .

${ }^{42}$ See, Halfpenny, 335. 
seem to be mentioned in other eighteenth century sources.

\section{Part twelve: trills}

Francoeur includes many more examples of trills on the half step than Roeser. 43 Vanderhagen distinguishes between "La Cadence préparée" and "La Cadence subito ou non preparée" with two short examples. He even includes a brief section on the "martellement" (mordent) in his tutor. 44 Trills, turns and beats (mordents) are explained only in Eeneral terms, without examples from the clarinet's range, in the English tutors.

\section{Part thirteen: articulation of sixteenth notes}

From Roeser's statement on the position of the reed, it is obvious that his clarinet was played with the reed pressed against the upper lip. Very few eighteenth century tutors or treatises deal with the question of embouchure. The first specific instruction occurs in The Clarinet Instructor:

Blow moderately strong the chalumeau notes, but for the clarinet notes the reed must be pinched with the lips a little and blown a little stronger: yet be careful that the teeth do not touch the reed in blowing. 45

The Compleat Instuctions [sic] does not offer any specific information on blowing the clarinet, but it includes an example

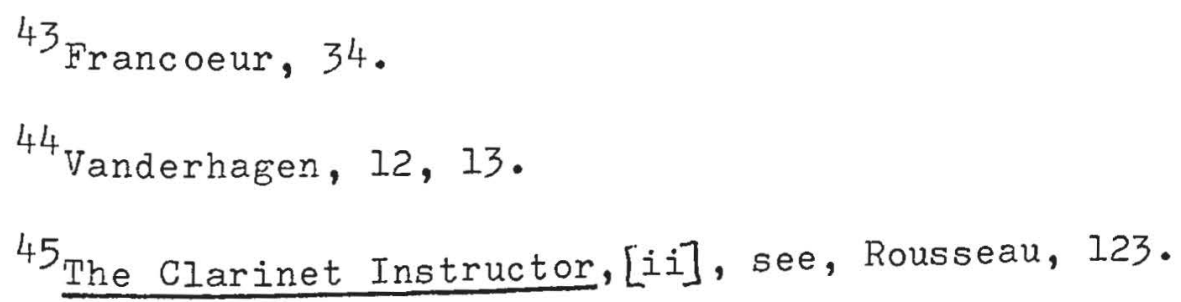


of notes marked $\rfloor\rfloor\rfloor$ and $1+1 ; j$. Vach is shown to be played as receiving one-half its own value. The only distinction offered between these articulations is the work "soft", appearing below the example of the dotted notes. 46

Vanderhagen appears to be the first to suggest to the clarinettist how to use the tongue to produce different articulations. His article five, "Differents coups de Iangue" is five papes in length. 47 He states that "the stroke of the tongue is to the wind instrument the same as the stroke of the bow on the string instrument". 48 Legato is achieved by pronouncing "d", staccato by pronouncing "t". The legato or connected notes ("Coups de Langue enchainés par $D^{\prime \prime}$ ) were not marked, but the staccato or detached notes (Coups de Langue detachés par $t^{\prime \prime}$ ) are marked with a dot. A later edition of this tutor changes these terms to tĥu for the legato notes and té for the staccato notes. 49 That these directions still apply to the upper-lip embouchure is substantiated by Vanderhagen's remark in another edition of his tutor:

${ }^{46}$ Compleat Instuctions [sic], 7, see, Rousseald, 131. 47 Vanderhagen, 5-9. ${ }^{48}$ Ibid., 5.

${ }^{49}$ Amand Vanderhagen, Nouvelle méthode de clarinette (Paris: Pleyel, 1803 or 1804), 36. See, Rousseau, 131. 
Support the mouthpiece on the teeth and cover the reed with the upper lip in no case touching the reed with the upper teeth. 50

Cnly gradually in the nineteenth century did clarinettists change their embouchure by putting the reed against the lower lip. This allowed for a much greater freedom in articulation, as well as a greater control of the entire range of the instrument. 51

\section{Part fourteen: a general rule for composers}

Although Roeser admonished composers to avoid great leaps in their writing for the clarinet, most of them included many leaps in their concertos and chamber music during the eighteenth century. His advice to composers reflects a careful and restrained attitude that is perhaps typical of his own time. The pieces that were given at the end of the book are sextets by Roeser for two clarinets, two horns and two basses.

50 Amand Vanderhagen, Méthode mouvelle et raisonnée pour la clarinette (Paris: Nadermann, c. 1780), 5, see, Titus, 79, Warner, 57, cf. Thomas Warner, "Indications of performance practise in woodwind instruction books of the 17 th and 18 th centuries" (Ph. D. dissertation, New York University, 1964), 89.

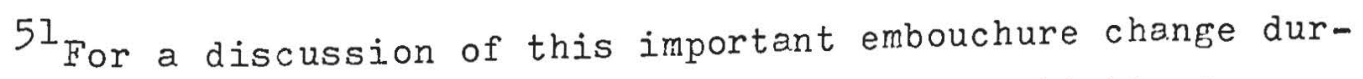
the nineteenth century see, Heinz Becker, "Zur Geschichte der Klarinette im 18. Jahrhundert," $\mathrm{Yif}_{\text {f }}$ (1955): 283-286, trans. by Don Halloran (August 1971), 19-25 (typewritten); MGG (1958), s.v. "Klarinette: C. Die europhische Klarinette," by Heinz Becker, 7: cols. 1015-1016, trans. by Dyke Kiel, The Clarinet 2, no. 4 (August 1975): 24 . 
ABBREVIATIOHS USED IN THE LTFEIDIXES

\begin{tabular}{|c|c|}
\hline BUCEY: & The British Union-Catalogue of Early Music \\
\hline & Erinted before the Year 1801. \\
\hline cem. & cembalo (harpsichord). \\
\hline cha. & chalumeau. \\
\hline$\underline{D D T}$ & Denlrmbler Deutscher Tonkunst. \\
\hline$\underline{\mathrm{DTB}}$ & Denkmbler der Tonkunst in Bayern. \\
\hline EDIf: & Das Erbe Deutscher Musik. \\
\hline fl. & flute. \\
\hline Groves VI & Groves Dictionary of Music and Musicians, sixth \\
\hline & edition (to be published). \\
\hline$\underline{\mathrm{HLT}}$ & Ernst Iudwig Gerber, Historische-biographisches \\
\hline & Lexicon der Tonkunstler. \\
\hline hn. & horn. \\
\hline$\underline{\mathrm{MGG}}$ & Die Musik und Geschichte und Gegenwart. \\
\hline Quellenlexicon & Robert Eitner, Biographisch-bibliographische \\
\hline & Quellen-Iexicon der Musiker und Musikgelehrten. \\
\hline$\underline{\text { RISM }}$ & Répertoire Internationale des Sources Musicales. \\
\hline va. & viola \\
\hline vn. & violin. \\
\hline
\end{tabular}


APPENDIX A

This appendix presents a listing of all the musical works, reported in the scholarly literature, that snecify the use of a chalumeau. It is organized according to the format used in the International inventory of musical sources. Renertoire international des sources musicales. Einzeldrucke vor 1800 (RISM), editing by Karlheinz Schalger, Kassel: BHrenreiter, 1971-. The content of each listing provides if available: 1) composer and dates, 2) composition and date, 3) key indicated, 4) range of each chaluneau indicated, 5) location of MS, catalog number and/ or modern edition, and 6) source references. The library sipla used are those found in the above volumes of RISH. An alphabetical listing of the sigla denoted appears after anpendix B. As complete a listing as possible is provided even though some sources are incomplete and uncertain. Nevertheless, all this material was thought to be valuable in any further studies and therefore, was brought under one heading. All source references referred to in appendixes $A$ and $B$ are given in an abbreviated form below. Abbreviations of reference sources used in appendixes $A$ and $B$

Full bibliographic citations of the following references are given in the Bibliography pages 174-189. 
$\begin{array}{ll}\text { Becker } 1 & \text { Heinz Becker, "Das Chalumeau bei Telemann". } \\ \text { Becker } 2 & \text { Heinz Becker, "Tas Chalumeau im }\end{array}$

Bil1

Chatwin

Dart 1

Oswald Bill, Listings of chalumeau and clarinet

music from the Hessische Landes-und Hochschulbibliothek, Personal letter 11 January 1974.

R.B. Chatwin, "Handel and the Clarinet".

Thurston Dart, "The Earliest Collections of Clarinet Music".

Dart 2 Thurston Dart, "The Mock Trumpet".

Eitner Pobert Eitner, Quellenlexicon.

Gévaert François-Auguste Gévaert, A New Treatise on In-

strumentation.

Hermann MGG (196I), s.v. "Johann Melchior Molter," by

Friedrich Hermann.

Hunt Edgar Hunt, "Some light on the chalumeau".

Kroll 1 Oskar Kroll, "Das Chaluneau".

Kroll 2 Oskar Kroll, The Clarinet.

Lanning Edrard Lanning, "The Clarinet as the Intended Solo

Instrument in Johann Melchior Molter's Concerto 34 ".

Lawson Colin Lawson, "The Early Chalumeau Duets".

Menke Werne Menke, Das Vokalwerk Georg Philipp Telemann's.

Owen 1 ingela Maria Cwen, Information on music written for

the chalumeau, Personal letter 31 March 1977.

Owen 2 Angela Maria Owen, "The Chalumeau and Its Music".

Petzoldt Richard Petzoldt, Georg Philipp Telemann=Leben=und

ierk. 
Fincherle Marc Pincherle, Antonio Vivaldi et la Miusique Instrumentale.

Rendall 1 F. Geoffrey Rendall, "A Short Account of the Clarinet in छngland during the jighteenth and Ninetecnth Centuries".

Rendall 2 F. Geoffrey Rendall, The Clarinet.

Scott Maxyne Mathisen Scott, "The Clarinet in France in the Mid-18th Century".

Thaler Alan Thaler, "Der Getreue lusic-Meister: A 'Forgotten' Periodical".

Van der lieer 1 John Henry van der Meer, "Some More Denner Guesses".

Van der lieer 2 John Henry van der Meer, "The Chalumeau Froblem".

Weston Pamela Weston, Clarinet Virtuosi of the Past.

Whitwell David Whitwell, "Clarinet Manuscripts in Vienna". 
A IIST OF MUSICAL TOPHS USING THE CHALUMEAU

I. Vocal Works:

A. Cantatas.

Bach, Johann Iudwig (1677-1741) - Cantata bey der Zuruckkunft Hochfurstl. Durchl. Herre Herzog Anton Ulrich aus Wien in dero Fochfurstl. Residenz Meiningen, 1728 - B-flat major f' to b''-flat (treble clef) - D-bra(B) - Owen 1, Owen 2. Caldara, Lntonio (1670-1736) - Non n'è pena - D-brd(DS), Mus. $1046 / 8-$ Bill.

Conti, Francesco Bartolomeo (1681-1741) - Con più luci, cantata per una voce - g' to b''(violin clef) - A(wgm), III/1471 Becker 2 .

- Fra questa umbrose pinate - D-brd(DS), Mus. 1046/2 Bill.

Graupner, Christoph (1687-1760) - Es begab sich dass Jesus in eine Stadt mit Namen Nain ging, 1737 - first part - C to g (bass clef), second part - C to e (bass clef) - D-brd(DS), Nius. 7337/22, DDT vol. 51-52 - Kroll 1. KOnig, Johann Ulrich (1688-1744) - Auf zur Iust - D-brd(F) Kroll 1.

Telemann, Georg Philipp (1681-1767) - Christus ist um unserer Missetat willen, 1721 - Becker 2. - Danket dem Herrn Zabaoth, 1718 - D-brd(F) - Kroll 1, 
Telemann, Georg Philipp (1681-1767) - Der feste Grund Gottes besteht, 1721 - D-brd(F) - Kroll 1, Becker 2. - Mit Gott in Gnadenbunde stehen - D-brd(F) - Kroll I, Becker 2. - Sehet man die Exempel der Alten, 1748 - Becker 2.

\section{B. Operas.}

Ariosti, Attilio (1666-c.1740) - Marte placato, Serenata, 1707 $A\left(W_{n}\right)$ - Kroll 2, Rendall 2, Eitner.

Bononcini, Antonio Maria (1675-1726) - La Conquista delle Spagne di Scipione Africano il giovane, 1707 - A(Wn), Ms. 18264/ 275 P - Kroll 2, Rendall 2, Eitner.

Bononcini, Giovanni Battista (1670-1755) - Endimione, 1706 A(Wn), Ms. 17685/86 P - Van der Meer 2, Eitner. - Turno Aricino, 1707 - A(Wn), Ms. 17690/91 P; GB(Lbm) Ms. 430 - Van der Meer 2, Eitner. - - Il Natale di Giunone festeggiato in Samo, 1708 - $\mathrm{A}(\mathrm{W} / \mathrm{n})$, Ms. 18271/72 P - Eitner.

Fux, Johann Joseph (1660-1741) - Julo Ascanio re d'Alba, 1708 $B$ major - first part, f' to $b^{\prime \prime}=$ flat (violin clef); second part, ' $f$ ' to $g$ "' (violin clef); third part, $F$ to b-flat (bass clef) - John .Henry van der Meer, J.J. Fux als Operkomponist, 4 vols., Utrechtse bijdragen tot de Musikwissenschaft II (Bilthoven: Creyghton, 1961), vol. 4, Johann Joseph Fux Sumtliche Werke, Series V, vol. I (Kassel-Graz, 1962) - Van der Meer 1, Becker 2. 
Fux, Johann Josenh (1660-174I) - Pulcheria poemetto dramatico, 1708 - B major - b' to c''l (violin clef) - D-ddr(DIb), ís. B213 P, Johann Joseph Fux Sumtliche Verke, Series V, vol. 2 (Kasse1-Graz, 1967) - Becker 2, Fitner. - Il Mese di Marzo consecrato a Narte, 1709 - Van der lieer 2 .

- Gli Ossequi della Votte, 1709 - Van der Keer 2.

- La Decima Fatica d'Ercole ovvero La Sconfitta di Gerione in Spagne, 1710 - Van der Meer 2.

- Dafne in lauro, 1714 - Van der Meer 2.

- Orfeo ed Euridice, 1715 - Van der Keer 2.

- Diana placata, 1717 - Van der Meer 2.

- Psiche (in collaboration with Caldara), 1720 - Van der Yeer 2 .

- Giunone placata, 1725 - f' to b''-flat (treble clef) A(Wn), Sig. 17.268 - Kroll 1, Eitner.

Gluck, Christoph Willibald (Ritter von) (1714-1787) - Orfeo, 1762 - "Chiamo il meo ben cosi", f' to e''-flat (treble clef) - RISM G 2842 - Kroll 1, Rendall 2, Owen 2. - Alceste, 1767 - f' to a'' (treble clef) - D-ddr(Bds), RISM G 2638 - Kroll 1, Eitner.

Handel, George Frideric (1685-1759) - Riccardo Primo, 1727"Quell innocente afflitto", d' to c'"' (treble clef); "Quando ne vedo la cara madre", f' to c'"' (treble clef) $\mathrm{GB}(\mathrm{Lbm})$, Mus. ms. Riv, 20.c.2, ff. 1-146, page $109-$ Chatwin, Owen 2 . 
Hasse, Johann Ádolph (1699-1783) - Alfonso, 1738 - B(BC), D-ddr (DIb) - Kroll 1, Eitner.

Keiser, Reinhard (1674-1734) - Der hochmutige, gesturtzte und erhabene Croesus, 1710 and 1730 - 1710, F major - first part, b to a'" (treble clef), second part, g' to d'' (treble clef), third oart, d' to $\mathrm{c}^{\prime \prime}$ (treble clef); 1730, A major - first part e' to g''-sharp (treble clef), second part, d'-sharp to c''-sharp (treble clef), third part, b to a' (alto clef) - D-brd(B), B(Bc), US(STu); DDT.vol. 37-8 Kroll 1, Owen 1, Owen 2, Eitner. - - Serenata, auf die Vermusslung, 1716 - "Zar in Dunff", first part, g' to a'" (treble clef), second part, g' to f''sharp, third part, ,C to $c$ (bass clef)-D-brd(B), Mus. ms. 11495 F - Kroll 1, Eitner.

Steffani, Agostino (1654-1728) - Il Turno (Amor vien dal destino), 1709 - first part, f' to f'' (treble clef), second part, bflat to $c^{\prime \prime}$ (treble clef), third part, c to $g^{\prime \prime}$ (treble clef), fourth part, col basso-GB(Lbm), R.M. 23. h.2. - Kroll 2, Eitner.

Telemann, Georg Philipp (1681-1767) - Genserich, Sieg der Schbnheit, 1724 - first part, c'' to f'"' (treble clef), second part, f' to b'' (treble clef) - D-brd(B), lis. 21777 P Kroll 1, Eitner. Ziani, Marc Antonio (1653-1715) - Caio Pompilio, 1704 - A(igm), Mus. 2398, A(Wn) - Rendall, Kroll 2, Eitner. 


\section{Oratorios.}

Bonno, Giuseppe (1710-1788) - Eleazaro, 1739 - b'-flat to b'' flat (treble clef) - A(Ngm), A(in), 17054/55 F - Kroll I, Eitner.

Bononcini, fntonio Maria (1675-1726) - Il trionfo della grazia, overo La conversione de Maddalena, 1707 - $\Lambda(W n)$ - Van der Pieer 2, Eitner.

Hasse, Johann Adolph (1699-1783) - La virtu al pie della croce, 1737 - f' to f'' (treble clef) - D-ddr(DIb) - Kroll I, Eitner.

Telemann, Georg Philipp (1681-1767) - Seliges Erw甘gen, "Es ist vollbracht", first part, c' to d"' (violin clef), second part, $F$ to b (bass clef) - D-ddr $(S W I)-$ Becker 2 . Vivaldi, Antonio (1678-1741) - Juditha triumphans devicta Holofernis barbarie - "Veri, veri me sequere", a' to b''-flat (treble clef) - I(Tn), US(STu), M2000V85 J9a - Owen 1, Owen 2.

II. Instrumental Works:

A. Chamber Works.

Airs à deux Chalumeaux, deux Trompettes, deux Hautbois, deux Violins, deux Flates, deux Clarinelles ou Cors de Chasse, livre premier, no. 348; livre second, no. 349, first ed., 1707-1716, second ed., 1717-1722 - first part, a to b'', second part, d to b' - $B(B c)$, classmark 5606; Klarinetten Duette aus der Fruhzeit des Instrumentes, ed. Heinz Becker, 
Collegium Musicum, no. 106, Viesbaden: Breitkopf \& Hartel, 1954, no. 2106 - Dart 1, Kroll 2.

Airs Anglois pour le Chalumeau - 1716 catalog of Roger et Le Cene - Vieston.

The Fourth Compleat Book for the Mock Trumpet, 1706-1708 -

first and second parts, $g$ to $a^{\prime}$ (treble clef) - GB(Ge), classmark B.e.19- Dart 2.

Dittersdorf, Karl Ditters von (1739-1799) - Divertimento Notturno for vn., cha., 2 vla., 2 hns., and bass - f' to c''' (violin clef) - A(Wgn), Mus. XI/16950 - Kroll 1, Becker 2. Dreux, Jacques Philippe (fl._1730) - Airs à deux Clarinettes ou deux Chalumeaux, composées par Mr. Dreux - 1716 catalon, of Roger et Le Cene, no. 358 - Rendall 2, Pincherle, Lawson. - Fanfares et autres airs de Chalumeaux à ? dessus - 1706 and 1716 (no. 193) catalog of Roger et Le Cene - Rendall 2, Kroll 2, Lawson.

- Fanfares pour les Chalumeaux et les Trompettes, propres aussi à jouer sur les flutes, violons et hautbois, a 2 et 3 parties composés par Jacques Philippe Dreux - 1706 and 1716 (no. 163) catalog of Roger et Le Cene - g' to g''(treble clef) - D-brd(W), RISM D 3546 - Owen 2, Lawson. - Fanfares pour les Chalumeaux, les Doubles Flutes, et les Trompettes, propres aussi à jouer sur les Flutes, Violons et Hautbois - 1706 and 1716 (no. 133) catalog of Roger et Le Cene - $g^{\prime}$ to $g^{\prime \prime}$ (treble clef) - D-brd (W), RISM D 3546 Owen 2, Lawson. 
Dreux, Jacques Philippe (fl. 1730) - Livres de pieces pour les Flutes, les Hautbois, le Chalumeau et pour les Violins a la Francoise a 2, 3, et e parties - 1706 catalog of Etienne Roger - Owen 2.

Graupner, Christoph (1687-1760) - Ouverture for cha., 2 vns., va. and cem., c. 1743 - B major - d' to c''l (violin clef) D-brd(DS), Mus. 464/59 - Becker 2, Bill.

- Ouvertlire for cha., fag., 2 vns., va. and cem., c. 1737 C major - C to $f$ (bass clef) - Dabra(DS), Mụs. 464/80 - Becker 2, Bill.

- Ouverture for fl. traverse, va. d'amore, cha., 2 vns., va. and cem?, c. 1732 - F major - F to b-flat (bass clef) - D-brd (DS), Mus. 464/79 - Becker 2, Bill.

- Ouverture for 2 cha., 2 vns., va. and cem., c. 1735-37 - F major - first part, $G$ to b-flat (bass clef); second part, C to $f$ (bass clef) - D-brd(DS), Mus. 464/41 - Becker 2, Bill. - Ouverture for 2 hns., typ., 2 cha., 2 vns., va., fag. and cem., October 1746 to January 1747 - F major - first part, F to b-flat (bass clef); second part, C to $f$ (bass clef)D-brd(DS), Mus. 464/7 (incomplete) - Becker 2, Bill. - Ouverture for 3 cha., c. 1741 - F major - first part, c' to f' (soprano clef); second part, F to b-flat (bass clef); third part, C to $f$ (bass clef) - D-brd(DS), Mus. 464/43; Suite F Dur fur drei Blockflbten oder andere Melodieinstrumente, ed. Dietz Degen, New York: C.F. Peters, 1943, no. 4564; 
First Suite for three Clarinets, ed. Edgar Hunt, London:

Schott, 1961, no. 10750 - Hunt, Becker 2, Bill.

- Ouverture for 3 cha. - C major - first part, $c^{\prime}$ to d'

(soprano clef); second part, F to b-flat (bass clef);

third part, C to $f$ (bass clef) - D-brd(DS), Mus. 464/73;

Second Suite for three Clarinets, ed. Edgar Hunt, London:

Schott, 1961, no. 10751 - Hunt, Becker 2, Bill.

- Ouverture for fl. traverso, va. d'amore, 2 cha., corno di selva, 2 vns., va. and cem., 1735 - C major - first part, F to $b$-flat (bass clef); second part, C to $g$ (bass clef) - Dbrd(DS), Mus. 464/32 - Becker 2, Bill.

- Ouverture for 3 cha., 2 vns., va. and cem., c. 1741 - C

major - first part, c' to d'' (soprano clef); second part, G to b-flat (bass clef); third part, $C$ to $f$ (bass clef) - Dbrd(DS), Mus. 464/2 - Becker 2, Bill.

- Ouverture for 3 cha., 2 vns., va. and cem., c. 1741 - F major - first part, $c^{\prime}$ to $d^{\prime \prime}$ (soprano clef); second part, G to b-flat (bass clef); third part, $C$ to $f$ (bass clef) - Dbrd(DS), Mus. 464/21 - Becker 2, Bill.

- Ouverture for 3 cha., 2 vns., va. and cem., c. 1741 - D minor - first part, $c^{\prime}$ to e'' (soprano clef); second part, F to b-flat (bass clef); third part, C to $f$ (bass clef) - Dbrd(DS), Mus. 464/38 - Becker 2, Bill.

- Trio for va. d'amore, cha. and cem., c. 1735-37 - F major -

C to $f$ (bass clef) - D-brd(DS), Mus. 471/2,5; GB(Lbm) MiSS.

3/6976 - Kroll 1, Becker 2, Bill. 
Graupner, Christoph (1687-1760) - Trio for fag., cha. and cem., c. 1737 - C major - C to f (bass clef) - )-brd(DS), Mus. 471/2,6 - Becker 2, Bill.

Heinichen, Johann David (1683-1729) - Pastorale per la Notte della Nativitate Christi for 2 obs. en cha., 2 obs. ripien, vns., vlas., and bassi soliti ( 2 fl., fg.) - A major - first part, $g^{\prime}$ to $c^{\prime \prime \prime}$ (viclin clef); second part, f-sharp to b''-flat (violin clef) - D-ddr(DIb), Musik 2398/0/13 a - Becker 2. Molter, Johann Melchior (1696-1765) - Sinfonia for 2 cha., 2 hns. and fag. - C major - first part, $c^{\prime}$ to $e^{\prime \prime}$ (violin clef); second part, C to a (bass clef) - D-brd(KA), Mus. Hs. 675 Becker 2 .

- Sonata for 2 hns., 2 cha. and fag. - F major - first part, $c^{\prime}$ to $f^{\prime \prime}$ (violin clef); second part, F to d' (bass clef) D-brd (KA), Mus. Hs. 508 - Becker 2.

Telemann, Georg Philipp (168 -1767) - Carillon a 2 Chalumeaux, ou Flute a bec ou trav. avec la Basse, 1728 - Achte Lection der Music-Meisters, page 32 - D-brd(B), Signature Mus. 12028 - Thaler.

- Concerts a neuf parties for cha., ob., fl. traversiere, vn. I, vn. II, vlas., bassecontre I, bassecontre II and b.c. G major - d' to $e^{\prime \prime}$ (soprano clef) - D-brd(B), l'us. ms. autogr. Telemann 3 - Kroll 1.

- Ouverture for 2 cha., 2 vlas. and bass - F major - first part, $f$ ' to b''-flat (French violin clef); second part, $F$ to b-flat (bass clef) - D-brd(DS), Mus. 1034/10 - Becker 2, Bill. 
Telemann, Georg Philipp (1681-1767) - Sonata for 2 cha. and unison vns. - F major - first part, $c^{\prime}$ to f'' (soprano clef); second part, F to b-flat (bass clef) - D-brd(DS), Mus. 1942/14 Becker 2, Bill.

\section{B. Concertos.}

Fasch, Johann Friedrich (1688-1758) - Concerto for cha., 2 obs., 2 vns., va., bassono, bass, bass ripieno and cem., between 1734 and 1745 - B major - $f^{\prime}$ to $c^{\prime \prime \prime}$ (violin clef) - D-ddr(Dlb), Musik 2423/0/12 - Becker 2.

Gassman, Florian (1729-1774) - Notturno for chalamaux and orch. A(Wn) Mus. ms. Sm 11394 - Whitwell.

Graupner, Christoph (1687-1760) - Concerto for cha., va. d'amore and ob., c. 1737 - B major - F to b-flat (bass clef) - D-brd (DS), Wus. 411/6 - Becker 2, Bill, Kroll 1. - Concerto for cha., fag. and cello, c. 1737 - C major - C to f (bass clef) - D-brd(DS), Mus. 411/26 - Becker 2, Bill, Kroll 1.

- Concerto for 2 cha., 2 vns., va. and cem. - C major first part, $c^{\prime}$ to e'l' (soprano clef); second part, $C$ to $f$ (bass clef) - D-brd(DS), Mus. 411/41 - Becker 2, Bill, Kroll 1. - Concerto for fl. traverse, va. d'amore and cha., c. 1732 F major - F to b-flat (bass clef)-D-brd(DS), Mus. 4ll/3I Becker 2, Bill, Kroll 1. 
Graupner, Christoph (1687-1750) - Concerto for 2 cha., 2 vns., va. and cem., c. 1735-37 - F major - first part, F to b-flat (bass clef); second part, $C$ to $f$ (bass clef) - D-brd(DS), Mus. 4ll/50 - Becker 2, Bill, Kroll 1.

Hasse, Johann Adolph (1699-1767) - Concerto - f' to b''-flat (treble clef) - D-ddr(Dlb) - Kroll l.

Hoffmeister, Franz Anton (1754-1812) - Concerto for Schalamaux and orch. - A(Wgm), Mus. ms. VIII 1404 - Whitwell. Telemann, Georg Philipp (1681-1767) - Concerto for 2 cha. and 2 fag., vns. unison, vals, bass - C major - first part, $c^{\prime}$ to f'' (sounding) notated in the part, $f$ ' to b''-flat (soprano clef); second part, F to b-flat (bass clef)-D-brd(DS), Mus. 1033/38 - Becker 2, Bill, Kroll 1. - Concerto for 2 cha., vns. 1 and 2, va. and cem. - D minor - first part, f' to b'' (French violin clef); second part, F to b-flat (bass clef) - Dubrd(DS), Mus. 1033/38; Concerto for 2 Clarinets (Chalumeaux) \& Strings, ed. Hermann Dechant, London: Musica Rara, 1973, no. 1633 a/b - Becker 2, Bill, Kroll 1.

Vivaldi, Antonio (1678-1741)-Concerto for 2 fls., 2 tiorbe, 2 mandolines, 2 Salmò, 2 vns, in tromba marina and cello (Fanna XII, no. 37; P. 16), c. 1740 - C major - first part, $G$ to $e^{\prime}$ (bass clef); second part, G to e' (bass clef) - Dddr(Dlb), Nusik 2389/0/4(a); Concerto in Do maggiore, ed. Gian Francesco Malipiero, Milano: Ricordi, 1960, tomo 318 Becker 2. 
Vivaldi, Antonio (1678-1741) - Concerto for $2 \mathrm{fls.,} \mathrm{ob.,} \mathrm{salmoe,}$ 2 trombe, vns., 2 vlas., strings and 2 cembs. (Fanna XII, no. 23 ; P. 87) - C major - $G$ to c (bass clef) - I( $\left.T_{n}\right)$, Renzo Giordano collection, 34, cc. 115r-132v; Concerto in Do maggiore, ed. Gian Francesco Malipiero, Milano: Ricordi, 1952, tomo 51, the salmoe is replaced by an english horn transposed upward by an octave. - Owen 2, Van der Meer 2. - Concerto "Funebre" for ob. sordini and salmoe, va. all' Inglese, vns. and vlas, sordini, but not the principal vn. (Fanna XII, no. 12; P. 385) - B-flat major - F to b-flat (bass clef) - I(Tn), Niauro Foa collection, 32, cc. 349r-359v; Concerto "Funebre" in Sib maggiore, ed. Angelo Ephrikian, Milano: Ricordi, 1949, tomo 142, the salmoe is replaced by an english horn transposed upward by an ocatave - Owen 2, Pincherle. - - Concerto for 3 obs., fag., 2 hns., vn., strings and cem. (Fanna XII, no. 33, P. 359) - G minor - "Basione" part - I $(T n)$, Mauro Foa collection; Concerto in Sol minore, ed. Gian Francesco Malipiero, Milano: Ricordi, 1956, tomo 249 - Van der Meer 2. 


\section{APPENDIX B}

This appendix presents a listing of all the musical works, reported in the scholarly literature, that specify the use of a two-key clarinet. It employs the same format as appendix A in the content of each listing and their organization. 
A LIST OF WUSICAL IORKS USING THE TOOKEY CLARINET

I. Vocal ivorks:

A. Cantata.

Telemann, Georg, Philipp (1681-1767) - Cantata for Whitsunday, 1721 - Menke, Kroll 2.

\section{B. Mass.}

Faber, Jean Adam Joseph - Maria Assumpta, 1720 - "Qui tollis peccata mundi", F to a'' (treble clef) - Gévaert, Rendall 2 , $\operatorname{Krol1} 2$.

\section{Operas.}

Conti, Francesco Bartolommeo (1682-1732) - Don Chisciotte in Sierra Morena, 1719 - A(igm), Ms. 17207 P, A(Wn), D-brd(B), Nis. 4076 P - Becker 2, Eitner.

Handel, George Frideric (1685-1759) - Tamerlano, "Granville" copy, c. 1740-1750-GB(Lbm), Mus. ms. Eg. 2920, vol. XI, ff. 1-110, RISM H 350 - Chatwin, Rendall 1, Rendall 2, Kroll 2. Rameau, Jean-Philippe (1683-1764) - Castor et Pollux, 1738 $A(\mathrm{gm}), \mathrm{A}\left(W_{n}\right), B(B c), D-b r d(B), D-b r d(D S), F\left(P_{c}\right), F(P n)$, $F(P o), G B(c f m), G B(I b m), I(B c)$ - Scott; Eitner. 
Rameau, Jean-Philippe (1683-1764) - Temple de la gloire, 1745 $F\left(P_{n}\right), F\left(P_{0}\right)-S c o t t$, Eitner.

Telemann, Georg Philipp (1681-1767) - Yiriway, 1728 - D-brd(B), Hs. 21778 P, GB(Lbm) - Petzoldt, Eitner.

II. Instrumental Works:

A. Chamber Works.

Airs à deux Chalumeaux, deux Trompettes, deux Hautbois, deux Violins, deux Flûtes, deux Clarinelles ou Cors de Chasse, livre premier, no. 348; livre second, no. 349, first ed., 1707-1716, second ed., 1717-1722 - first part, a to b' (treble clef); second part, a to b' (treble clef) - B(Bc), classmark 5606; Klarinetten Duette aus der Frthnzeit des Ins.trumentes, ed. Heinz Becker, Collegium Musicum, no. 106, Wiebaden: Breitkopf \& Hartel, 1954, no. 2106 - Dart 1, Kroll 2.

Dreux, Jacques Philippe (fl. 1730) - Airs à deux Clarinettes ou deux Chalumeaux, composees par Mr. Dreux - 1716 catalog of Roger et Le Cene, no. 358 - Rendall 2, Fincherle, Lawson. Krlbel, M (fl. 1730-1758) - Trio. Le Clarinet. Le Cornu De Schass, et Basso, c.1740 - D or C major - D-brd(DS), Mus. 1181 - Bill, Eitner. 
B. Concertos.

Molter, Johann Nelchior (1696-1765) - Concerto for clar. in D, strings and cem., c. 1747 - A major - c' to g''l' (treble clef) - D-brd(KA), Mus. ms. 304; EDM, vol. 41, wiesbaden: Breitkopf \& Hurtel, 1957 - Rendall 2, kroll ?, Eitner. - Concerto for clar. in D, strings and cem., c. 1747 - D major - $c^{\prime}$ to $f^{\prime \prime \prime}$-sharp (treble clef) - D-brd(KA), Mus. ms. 334; EDM, vol. 41, Wiesbaden: Breitkopf \& Hurtel, 1957 - Rendall 2, Kroll 2, Eitner. - Concerto for clar. in D, strings and cem., c. $1747-D$ major - g' to g''' (treble clef) - D-brd(KA), Mus. ms. 337; EDM, vol. 41, Miesbaden: Breitkopf \& Hartel, 19,57 - Rendall 2, Kroll 2, Eitner. - Concerto for clar. in D, strings and cem., c. 1747 - G major - $c^{\prime}$ to g''l' (treble clef) - D-brd(KA), Mus. ms. 302; EDM, vol. 41, Wiesbaden: Breitkopf \& HHrtel, 1957,- Rendall 2, Kroll 2, Eitner.

- Concerto for clar. in D, strings and cem., c. $1747-D$ major - d' to g''l' (treble clef) - D-brd(KA), Mus. ms. 332; Edward Francis Lanning, "The Clarinet as the Intended solo Instrument in Johann Melchior Molter's Concerto 34," D.M.A. dissertation, University of Missouri-Kansas City, 1969 Lanning •

- Concerto for solo instrument, strings and cem. - D-brd(KA), Hus. ms. 328 - Lanning, Hermann. 
Vivaldi, Antonio (1678-1741) - Concerto for 2 clars. in C, 2 obs., strings and cem. (Fanna XII, no. I; F. 73), c. 1740 - C major - first part, g to c'l' (treble clef); second part, f to c'l' (treble clef) - I(Tn), Renzo Giordano collection, 31, cc. 7?.r$87 \mathrm{v}$; Concerto in Do maggiore, ed. Angelo Ephrikian, Milano: Ricordi, 1947, tomo 3 - Rendall 2, Kroll 2. - Concerto for 2 clars. in C, 2 obs., strings and cem. (Fanna XII, no. 2; P. 74), c. 1740 - C major - first part, (r to c'"' (treble clef), second part, g to $c^{\prime \prime}$ (treble clef) - I(Tn), Renzo Giordano collection, 31, cc. 90r-103v; Concerto in Do maggiore, ed. Angelo Ephrikian, Milano: Ricordi, 1947, tomo 10 - Rendall 2, Kroll 2.

- Concerto "per la Solennita di S. Lorenzo" for 2 fls., 2 obs., 2 clars. in C, fag., 2 concertante vns., strings and cem. (F̣anna XII, no. 14; P. 84), c. 1740 - C major - first part, c' to d''l(treble clef); second part, 8 to c'l' (treble clef) - I(Tn), Renzo Giordano collection, 34, cc. 2r-20v; Concerto in Do maggiore, ed. Angelo Ephrikian, Milano: Ricordi, 1949, tomo 54 - Rendall 2, Kroll 2. 
LIBRARY AND MUSEUY SIGLA

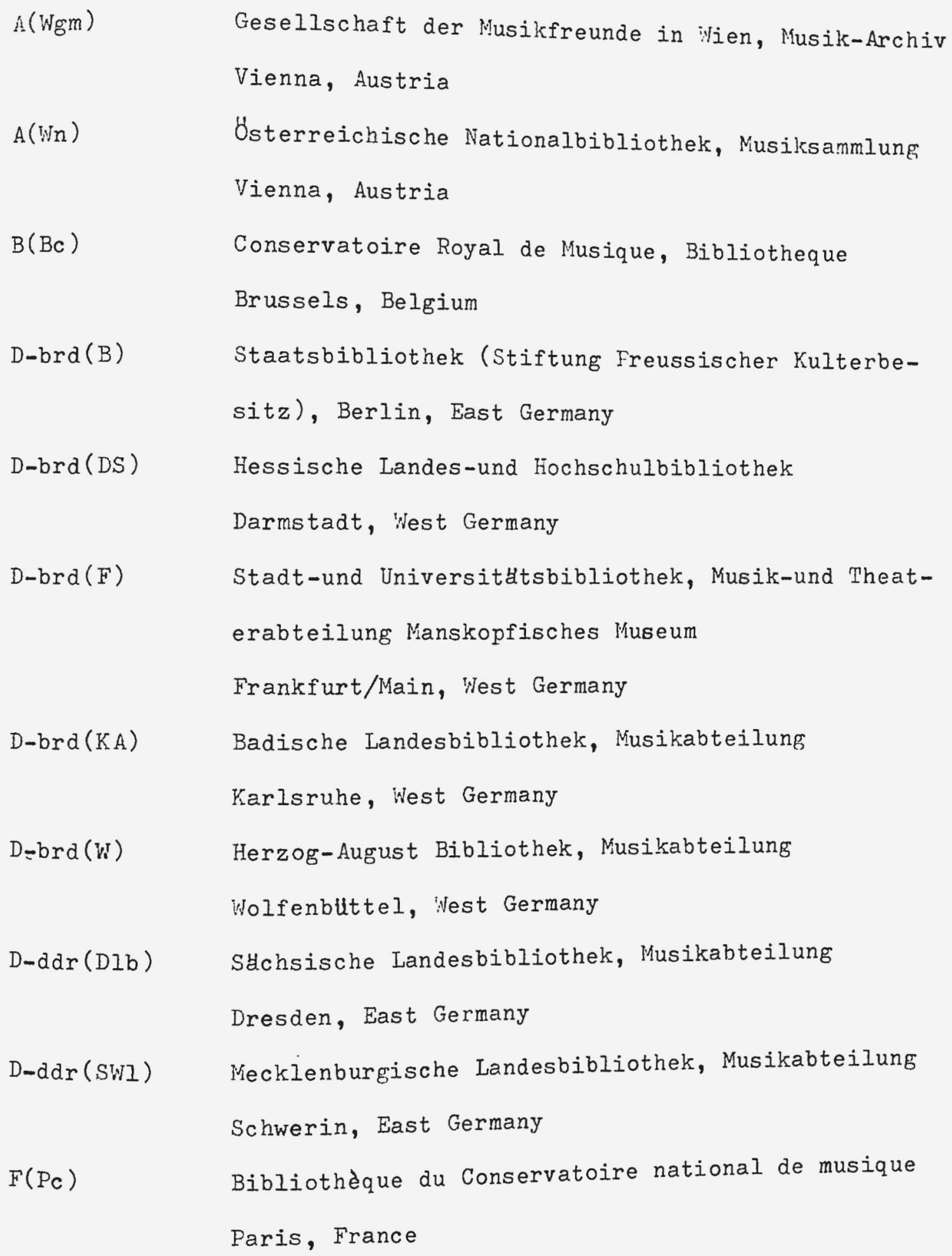




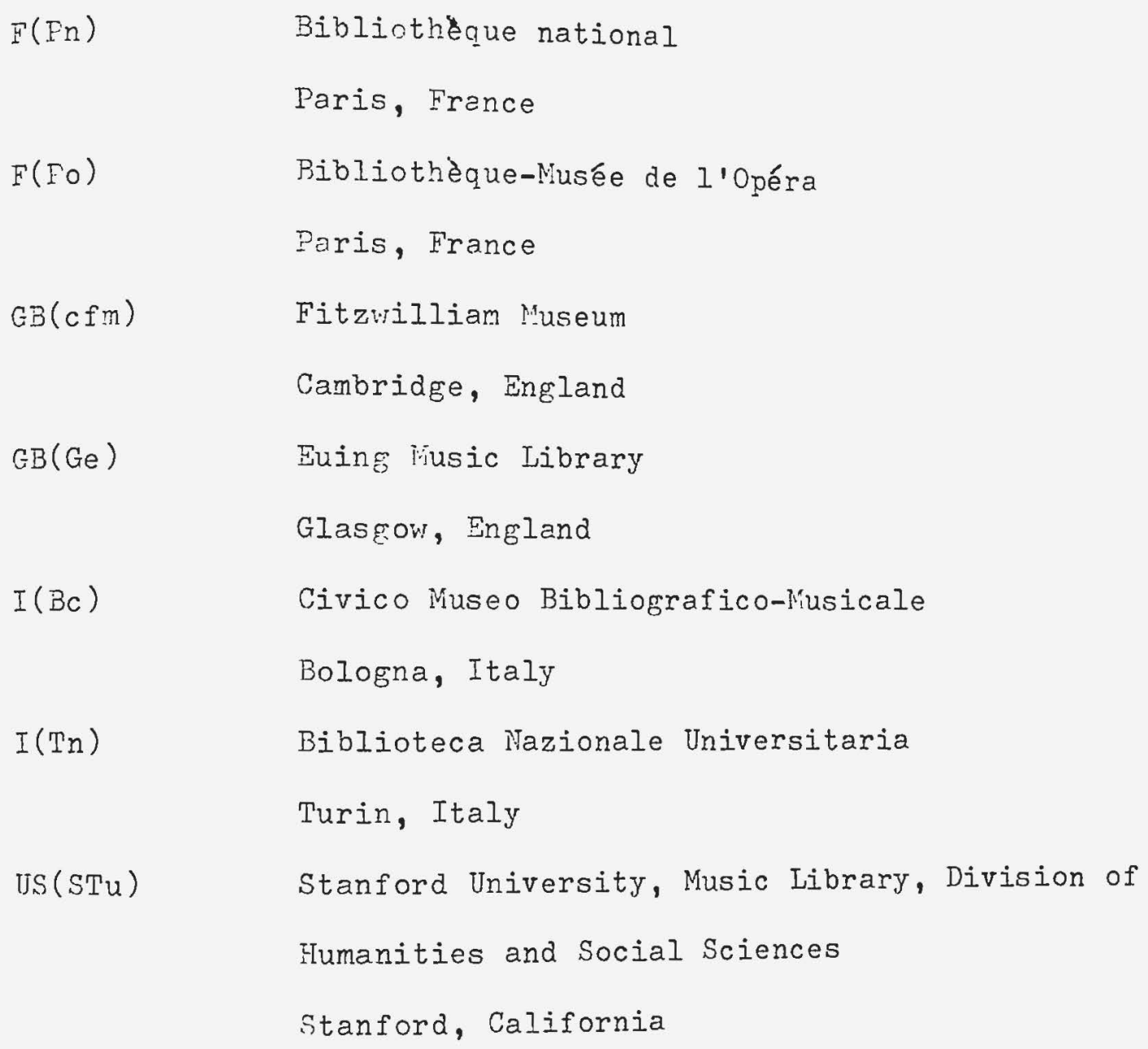


APPENDIX C

This listing presents the most important eifhteenth century instructional materials that deal with the chalumeau and clarinet found in the scholarly literature. Complete bibliographical listings are attempted, as well as specific page numbers in larger works, where the pertinent information may be found. Some of the longer titles of books are shortened. Clarinet tutors that anpear in Thomas Varner's An Annotated Bibliography of Woodwind Instruction Books, 1600-1830 are noted at the end of the citation using a capital $N$ and the number of the tutor or treatise found in this book. In some cases, tiarner's information was supplemented by Adrienne Simpson's, "A Short-Title List of Printed Instrumental Tutors up to 1800, Held in British Libraries," R.M.A. Research Chronicle, no. 6 (1966), 24-50. This information is also noted at the end of the citation by using a capital $S$, with the page number that corresponds to the tutor in this article. 
A CHROIOUOGICAL LISTING OF IMGTRUCTIONL ATRRIALS

FOR THE IIGHT GEITH CENTURY CHLUYEAU IKD CLARIXET

The Fourth Compleat Book for the Mock Trumpet Containing Plain and Easy Directions to Sound the Vock Trumpet Together with Variety of new Trumpet Tunes Aires Narches \& Ninuets fitted to that Instrument, and Very Froper for the Brazen Trumpet, also severall First and Second Trebles for two Trumpets the whole Fairly Engraven, London: J. Walsh, J. Hare and F. Randall, c. 1707.

Walther, Johann Gottfried. Fraecepta der musicalische Composition, (1708), facsimile ed., ed. by Peter Benary, Jenaer Beitryge zur Píusikforschung, vol. 2, Leipzig: Breitkopf \& HHrtel, 1955, 43.

Mattheson, Johann. Das Neu-erbffnete Orchestre. Hamburg: B. Schillers Wittwe, 1713, 272.

Crousaz, Jean Pierre de. Traité de Beau. Amsterdam: Francois L'Honore, 1715, 239 .

Bonanni, Filippo. Gabinetto Armonico pieno d'Istromenti Sonori. Roma: Giorgio Flacho, 1722, 67-68. 
Weigle, Johann Christoph. Musicalisches Theatrum auf welchen alle zu dieser edlen Kunst gehbrige Instrumenta. Nurnberg: Joh. Christoph Weigle (before 1726), Documenta Musicologica, vol. 22, facsimile ed., ed. by Alfred Berner, Kassel: Barenreiter, 196I, blatt 14

Doppelmayr, Johann Gabriel. Historische Nachricht von den Nurnbergischen Mathematicis und Kunstlern. Nurnberg: P.C. Monath, $1730,305-306$

Najer, Joseph Friedrich Bernhard Caspar. Museum Musicum Theoretico Practicum das ist Neu-erbffneter Theoretisch-und Fractischer Music-Saal. Schwbb. Hall: Georg Michael Majer, 1732, Documenta Musicologica, vol. 8, facsimile ed., ed. by Heinz Becker, Kassel und Basel: Burenreiter, 1954, 32, 39.

Walther, Johann Gottfried. Musikalisches Lexicon oder musicalische Bibliothek. Leipzig: Wolffgang Deer, 1732, Documenta Musicolorica, vol., 3, facsimile ed., ed. by Richard Schaal, Kassel: Bürenreiter, 1953, 153-154; 168; 202-203; 218; Table IX.

Zedler, Johann Heinrich. Grosses vollstundiges Universal-Iexicon, 33 vols., Halle, 1732-1754, vol. 6(1733), 226 s.v. "Clarinetto"; vol. 7(1734), 569 s.v. "Denner, Joh. Christoph". 
St Ussel, Johann Christoph and Johann David StUssel, Kurzgefasstes Husikalisches Lexikon. Chemnitz: J.C. and J.D. Stbssel, 1737, s.v. "chalumeau".

[Eisel, Johann Fhilipp.] Musicus Autodidaktos oder der sich selbst informirende Musicus. Erfurt: Johann Michael Funcken, $1738,76-78 . W-71$

Majer, Joseph Friedrich Bernhard Caspar. Neu-eryffneter theoretisch und praktischer Music-Saal. Nurnberg: Johann Jacob Gremer, 1741,43

Encyclopédie, ou Dictionnaire raisonne des sciences, des arts et des metiers par un societe de gen de lettres. Mis en ordre : publie par m. Didertot... \& quant a la partie mathematique, par m. d'Alembert: - Faris: Briasson, David, Le Breton, 17 vols., 1751-1765, vol. 3(1753), 505.

Adlung, Jacob. Anleitung zu der musikalischen Gelahrtheit. Erfurt: J.D. Jungnicol, 1758, Documenta Musicologica, vol. 4, facsimile ed., ed. by Hans Joachim Noser, Kassel und Basel: Burenreiter, 1953, 588 .

[Ancelet.] Observations sur la musique, les musiciens, et les instrumens. Amsterdam: Aux depens de la campagnie, 1757, 33. 
Garsault, Francois Alexandre Pierre de. Notionaire, ou mémorial raisonné. Paris: Guillaume Desprez, 1761, 633, 646-647. W-101

Roeser, Valentin. Essai d'Instruction à l'usage de ceux qui Composent pour la clarinette et le cor. Paris: Le Menu, 1764, 212. $W-102$

[Anonymous Tutor, Title page missing] (c. 1765) in Eugene E. Róusseau, "Clarinet Instructional Materials from 1732 CA. 1825", Ph.D. dissertation, State University of Iowa, 1962, 25-26, 63.

Hotteterre, Jacques. Méthode pour apprendre à jouer en peu de de la flute. Paris: Bailleux, c.1765: W-42

Tansur, William. The Elements of Musick made easy: or, An Universal Introduction to the Whole Art of Musick. Book III. London:

Printed for S. Crowder, 1767, 114. W-113

Encyclopédie.. Recueil de Planches, sur les sciences, les arts mechaniques, avec leur explication... Il vols., Paris: Briasson, David, Le Breton, 1762-1772, vol. 5, plate 8.

Francoeur, [Louis-Joseph]. Diapason Général de tous les instruments à vent. Paris: Le Marchand, 1772; Paris: Des Lauriers, 1772 , reprint ed., Geneve: Minkoff Reprints, 1972. 
Principes de Clarinettes Avec la Tablature des Meilleurs Maitres pour cet Instrument et plusieur Duo pour cet Instrument. Faris: c. 1772 in Daniel Thomas Bogart, "A History of the Clarinet as an Orchestral Instrument from : Inception to Full Acceptance into the iloodwind Choir," Fh.D. dissertation, Michipan State University, $1968,23-25$

Encyclopédie... Supplement. Amsterdam: M.M. Rey, 4 vols. 17761777, vol. 2, 1775, 450-451.

Encyclopédie... Suite de Recueil des planches . . Faris: Fanckouche, Stoupe, Brunet, 1777, 143, supplemental plate 4. The Clarinet Instructor. London: Longman \& Broderip, c. 1780. $N-134$

[La Borde. Jean-Benjamin de.] Essai sur la musique ancienne et moderne. Paris: Ph. D. Fierres, 1780, 4 vols., vol. 1, 248252. $N-148$

Complete Instuctions (sic) for the Clarinet. London: S, A, ? P Thompson, c. 1785. W-156

Vanderhagen, Amand. Méthode Nouvelle et Raisonnée pour la Clarinette. Paris: Boyer et Le Menu, c. 1785; reprint ed. Geneve: Minkoff Reprint, 1972. W-157 
Vandenbrock, Othon. Traité Général de tous les instrumens à

vent. Paris:Boyer, 1793, 44-51. :i-1? 1

Reynvaan, Joos Verschuere. Muzikaal Kunst-woordenboek. Amsterdam: Nouter Brave, 1795, 149.

New and Complete Instructions for the Clarionet. London: Freston \& Son, c. 1797. W-187 S-48

New and Compleat Instructions for the Clarionet. London: A. Bland \& Weller's, c. 1798. W-191

Calcott, John Wall. "Clarinett", article from an unpublished Dictionary of Music, London: British Library, Add. 2.7680 . 
APPENDIX D

This listing presents a checklist of the musical works of Valentin Roeser gathered from the scholarly literature. The majority of these were taken from Barry s. Brook's article on Roeser in $\mathbb{M G G}$ and his article on Roeser that will be published in Groves VI. Other sources are noted in parenthesis and may be found fully cited in the Bibliography. 
A CHECKLIST OF MUSICAI TORKS BY VILENTIN ROESER

\section{Symphonies.}

Opus

1 Six Sonates à trois ou à tout l'orchestre $(E, g, D, E b, A, B b)$ (Paris, 1762).

- Symphonie Périodique No. 2 (Eb) (Bailleux, 1762); also appeared as No. 2 of Six Symphonies da vari autori, 4 th collection by Bailleux.

- Symphonie Fériodique No. 34 (Paris, c. 1763) lost.

IV Sei Sinfonie con obboe obligate e Corni da Cacia ad Libitum (G,Eb,F,Eb,D,Eb) (Paris, 1766); also appeared as Symphonies Périodiques XIX to XXIV.

$\mathrm{V}$ Six Simphonies à deux Violons Alto Viola et Basse obligées deux hautbois, et deux Cors ad Libitum (D,Eb,F,G,A,Bb) (Paris, c. 1772).

XII Six Simphonies à Grand Orchestre dont trois avec les Clarinettes et Cors Obligées (Eb, D, Bb, G,C,F) (Paris, 1776).

\section{Chamber Music.}

- Six Sonates pour le violon avec basse $(F, C, A, b, D, A)$ (Paris); DTB, vol. 28, Jahrgang XVI, xliv.

II Six sonates [duó] à deux violons (Paris, 1766)

III Six sonates [trio] à 2 violons et basse pouvant s'exécuter sur la mandoline (Paris, 1770) 
Opus

VI 12 Sonates très faciles pour le Clavecin ou le pianoforte (Paris, 1771; London, c. 1780, c. 1790, 1799); BUCEM, vol. $2,895$.

VIII (12?) Duo de clarinette (Paris, 1773).

X Six Sonates pour le forte piano suivies de remarques sur les deux genres de Polonoises (Paris, 1774).

XI Six Sonates pour le pianoforte avec accompagnrment de violon et six ariettes (Faris, 1775).

XII Six ?uatuor pour clarinette ou hautbois, violon, alto et basse (Paris, 1775, compare Six Symphonie Opus XII above).

XIII Suite des Duo de violon (Paris, 1775).

Romance "Sou les lois de la jeune Hortense..." (voice

and bass) text by $\%$.H. de I. published in Mercure de

France (June 1777).

\section{Chamber Music with Duplicate Opus Numbers.}

12 Petit Airs pour 2 clarinettes (violons) (Paris); DTB,

vol. 28, Jahrgang XVI, xix.

VI Duos faciles pour 2 violons (Paris, 1770); DTB, vol. 28, Jahroang XVI, xix.

$X$ Six Sonates pour le Clavecin avec violon obligé (Amsterdam); DTB, vol. 28, Jahrganp XVI, xix. 
Arrangements, Collections.

Le Bal germanique ou ler [also 2er] Recueil de Danses illemandes rassemblées et arrangées pour $?$ violons et basse (Paris, 1764).

Six Sonates Dour le clavecin avec accompagnement d'un violon; tirées des ouvrages de J. Stamitz. Suite I (Paris, 1768); DTB, vol. 28, Jahrgang XVI, xliv.

$I^{e}$ Suite de Soirée de Bagnolet (Opéra comique de Roeser?) (Paris, 1768).

$2^{\text {e }}$ Suite dé Soirée de Barnolet (Paris, 1769).

Duo de Tofferi mis en trio par Roeser (Paris, 1769).

$1^{\text {re }}$ Suite des Ariettes arr. pour 2 clar., 2 cors, 2 bassons (Paris, 1771).

4 Recueils de douze ariettes (voice and clavecin or pianoforte) choisies de differens opéras comiques (Faris, 17711775).

16 Recueils de Petits Airs (Duos for 2 Violons) (Paris, 1771-1775).

40 (approx.) Divertissements Militaires for 2 clars., 2 hns.,

2 bassoons (Paris, 1771-1782).

$9^{\text {e }}$ Suite des Airs arrangées pour 2 clar., 2 cors, 2 bassons (Paris, 1772). 
Duo pour 2 clarinettes (Paris, 1774).

Fremier Recueil de duo tires des opéras comiques avec accompagnement de clavecin ou pianoforte (Paris, 1774). Ouverture de Myrtile e Lycoris pour le clavecin (Van Ypen, 1776): Vander Straeten, La Musique aux Fay-Bas, vol. 2, 397 .

5 Recueils d'Ariettes d'Opéra comiques arrangées pour le clavecin avec paroles (Paris, 1775-1777).

2 Recueils d'airs d'Opéra comiques arrangées pour 2 clarinettes (Faris, 1777).

2 Recueils d'airs d'harmonie arrangées pour 2 clarinettes (Paris, 1777).

3 Recueils d'airs d'Opéra comiques arrangées pour 2 Flutes (Paris, 1777-1779).

5 Recueils d'Ariettes d'Opéra comiques arrangées pour 2 violons (Paris, 1777-1779)

Ouverture de Roland (Piccini) arrangée en quatuor (Paris, 1778)

Ouverture et 7 ariettes de Laurette (Haydn, Meraux?) arrangées en quatuor ou pour tout l'orchestre (Paris, 1778). Ouverture de l'Olympiade arrangée pour le clavecin ou pianoforte avec accompagnement de violon (Paris, 1773). Petits Airs pour le clavecin (Paris, 1779). 
Suite de Pieces d'harmonie for 2 clar., 2 cors, 2 bassons (Faris, 1782).

Recueil de XII Ariettes d'Opérá com. av. acc. de Clav. (Paris, 1792); Gerber, HIT, vol. 2, 898.

16 Marches et Airs a 2 clar., 2 cors, 2 bassons, (Berlin, 1813).

Ariettes du Silvain; et une de Iucile (par Gretry) arrang. par 2 clar., 2 cors, 2 bassons; Eitner, quellenlexicon, vol. 8,275 .

Ariettes et air de danse, tirès d'Ermelinde in opéra de Mr. Philidor arrang. par 2 clar., 2 cors, ? bassons; Eitner, Quellenlexicon, vol. 8, 275.

12 Pieces a 2 clar., 2 cors and 2 fag.; Eitner, Quellenlexicon, vol. 8, 275 .

\section{Pedagogic Works.}

Essai d'instruction à I'usage de ceux qui composent pour la clarinette et le cor (Paris, 1764).

I'Art de toucher le clavecin selon la manière perfectionnée des modernes (Paris, 1764); anonymous translation of Marpurg's Die Kunst des Clavier zu spielen, 1750.

Gamme et 6 duo pour la clarinette (Paris, 1769). Gamme et 12 duo pour le basson (Paris, 1769). 
Kethode raisonnée pour apprendre à jouer du violon (Paris, 1770); translation of Leopold hozart's Grundliche Violonschule, plus "On trouvera à la fin de cette Néthode XII Petits Duo et une Caprice Facile". Gamme du serpent (Paris, 177ว).

Gamme du hautbois et 12 duo pour cet instrument (Paris, 1777).

Gamme pour la flûte traversière et 12 duo pour cet instrument (Paris, 1777).

Méthode pour Flute (Paris: Chez Leduc); Pietro Lichtenthal, Dizionario e bibliografia della musica, 4 vols. (Milano: Antonio Fontana, 1826), 4: 111. 


\section{Books}

Adlung, Jacob. Anleitung zu der musikalischen Gelahrtheit. Erfurt: J.D. Jungnicol, 1758; Documenta Musicologica, vol. 4, facsimile ed., ed. by Hans Joachim Noser. Kassel und Basel: BHrenreiter, 1953.

Agricola, Martin. Musica Instrumentalis Deudsch. Wittenberg: Georgio Phaw, 1529; reprint ed. Hildesheim: 0lms, 1969.

Amman, Jost. Nappan-und-Stammbuch darinnen der Keys. Maiest. Chur und Fursten Graffen Freyherrn deren von Adel. Franckfort am Mayn: Sigmundt Feyrabends, 1589; reprint ed. Munchen: Hirth, 1881 .

Apel, Nilli. Harvard Dictionary of Music. Cambridge, Massachusetts: Harvard University Press, 1968.

Baines, Anthony. European and American Musical Instruments. New York: The Viking Press, 1966.

- Noodwind Instruments and their History. $3 \mathrm{~d}$ ed. Iondon: Faber and Faber, 1967.

Becker, Heinz. History of Instrumentation. Trans. Robert Kolben. Anthology of Music, 33 vols. Cologne: Arno Volk, vol. 24, 1964.

Bonanni, Filippo. Antique Musical Instruments and Their Players 152 Plates from Bonanni's 18th Century "Gabinetto Armonico". New intro. and captions by Frank LI. Harrison and Joan Rimmer. New York: Dover, 1964. 
Bonanni, Filippo. Gabinetto Armonico pieno d'Istromenti Sonori.
Roma: Giorgio Flacho, 1722.

The British Union-Catalogue of Barly Music Frinted before the Year 1801. A record of the holdings of over 100 libraries throughout the British Isles. Ed. B. Schnapper, 2 vols. London: Butterworths Scientific Publications, 1057.

Brook, Barry S. La Symphonie Française dans la Seconde lioitié XVIII ${ }^{\mathrm{e}}$ Siècle. 3 vols. Faris: Fublications de l'Institut de Yusicologie de l'Universite dé Faris, 1962.

Burgkmair, Hans. The Triumph of Maxmillian I. Trans. of text by Stanley Appelbaum. New York: Dover, 1964.

Carse, Adam. Musical Iind Instruments. London: Macmillan and Co., 1939.

Choron, Alexandre E. et F.J.Y. Fayolle. Dictionnaire historique des musiciens, artistes et amateurs, morts ou vivans. Faris: Valade, 1810-1811, 2 vols., reprint ed. Hildesheim: 01ms, 1971.

The Clarinet Instructor. London: Longman \& Broderip, c. 1780.

Complete Instuctions [sic] for the Clarinet. London: S.A. \& P. Thompson, c. 1785.

Cotgrave, Randle, A Dictionarie of the French and English tongues. London, 16Il; facsimile ed. with intro. by Hilliam S. Hoods. Columbia: University of South Carolina Press, 1950.

Crousaz, Jean Pierre de. Traité de Beau. Amsterdam: François I'Honord, 1715. 
Day, Charles Russell. A Descriptive Catalogue of the Yusical Instruments Recently Exhibited in the Royal Nilitary Exhibition, London 1890. London: Eyre \& Spottiswoode, 1891.

Den'smaler der Tonkunst in Bayern. Braunschweig: H. Litolff's Verlag, 38 vols., 1900-1938.

Denkmaler der Tonkunst in Österreich. Vienna: Artaria, 1894-.

Denkmbler Deutscher Tonkunst. Leipzig: Breitkopf \& HArtel, 65 vols., $1892-1931$.

Desainliens, Claude. A Dictionary French and English. London: Thomas Woodcock, 1593; facsimile ed. Nenston, England: Scolar Press, 1970.

Dlabað, Jan Bohumir. Allgemeines historisch Kunst-lexicon fur Bbhmen. 3 vols. Frag: G. Hesse, 1815; reprint ed. Hildesheim: 01ms, 1973.

Doppelmayr, Johann Gabriel. Historische Nachricht von den Nurenbergischen Mathematicis und Kunstlern. Nurnberg: F.C. Wonath, 1730.

[Eisel, Johann Philipp]. Musicus Autodidaktos oder der sich selbst informirende Musicus. Frfurt: Johann Michael Funcisen, 1738.

Eitner, Robert. Biographisch-bibliographische Quellen-Lexicon der Musiker und Nusikgelehrten. Leipzig: Breitkopf und Hurtel, 1899-1904, 10 vols.; reprint ed. New York: Musurgia, 1947.

Encyclopaedia Britannica. Ilth ed. Cambridge, England: At the University Fress, 32 vols., 1916. 
Encyclovédie, ou Dictionnaire raisonné des sciences, des arts et des métiers var un societe de gens de lettres. Mis en ordre \& publié par m. Diderot... \& quant à la partie mathématique, par m. d'Alembert... Paris: Briasson, David, Le Breton, 17 vols., 1751-1765.

Encyclopédie.. Recueil de Planches, sur les sciences, les arts mechaniques, avec leur explication... Faris: Briasson, David, Le Breton, 11 vols., 1762-1772.

Encyclopédie.. Suite de Recueil des Planches... Paris: Panckouche, Stoupe, Brunet, 1777.

Encyclopédie .. Supplement. Amsterdam: M.M. Rey, 4 vols., $1776-1777$.

Das Erbe Deutscher Kusik. Leipzig: Breitkopf \& Hartel, 1935-1942, 1954-。

Estienne, Robert. Dictionariolum Puerorium Tribus Linguis Latina Anglica e Gallica. London: Reginaldum Walsium, 1552; reprint ed. New York: Da Capo, 1971.

Fétis, Francois J. Biographie universelle des musiciens et bibliographie generale de la musique. 2me ed., 8 vols. Paris: Firmin Didot Freres, 1866-1870.

Fitzpatrick, Horace. The Horn and Horn Playing and the AustroBohemian Tradition from 1680 to 1830 . London: Oxford University Press, 1970.

Florio, John. Queen Anna's New World of Words or Dictionarie of the Italian and English tongues. London: printed by Kelch. Bradwood for Edw. Blount and William Barret, 1611. 
Forkel, Johann ITicolaus. Allgemeine litteratur der Musik. Leipzig: Nilachdruck der fusgabe, 1792; reprint ed. Hildesheim: $01 \mathrm{~ms}, 1962$.

Francoeur, [Louis-Joseph]. Diapason général de tous les instruments à vent. Paris: Des Lauriers, 1772; reprint ed. Genève: Minkoff Reprints, 1972.

Garsault, François Alexandre Pierre de. Notionaire, ou mémorial raisonné. Paris: Guillaume Desprez, 1761.

Gerber, Ernst Ludwig. Historisch-biographisches Lexicon der Tonkinstler. 2 vols. Jeipzig: J.G.I. Breitkopf, 1790-1792; reprint ed., ed. by Othmar Wessely, 4 vols. Graz: Akademische Druck-und Verlagsanstalt, 1966-1969.

Gévaert, François-Auguste. A New Treatise on Instrumentation. Trans. E.F.E. Studdard. Paris and Brussels: Henry Lemoine, $n \cdot d$.

Grand Larousse encyclopédique. 10 vols. Paris: Librairie Larousse, 1960-1964.

Handel, George Frederic. Sonata in D major for 2 Clarinets and Iorn or 3 Clarinets in $B^{b}$. Ed. for practical performance by J.M. Coopersmith and Jan LaRue. Bryn Mawr, Pennsylvania: Wercury iusic Corporation, 1950.

Hunt, Edgar. The Recorder and its Music. New York: W.W. Horton, 1962 .

Internationaz Inventory of musical sources. Répertoire international des sources musicales. Einzeldrucke vor 1800 . Redartion Karlheinz Schlager. Kassel, Basel, Tours, London:

BHrenreiter, 1971-• 
Johansson, Cari. French Music Publishers' catalogues of the Second Half of the Eighteenth Century. 2 vols. Stockholm: Almquist \& Yrsells, 1955.

Kircher, Athanasius. Musurgia Universalis sive ars magna consoni et dissoni. 2 vols. Romae: Francisci Corbelletti, 1650; reprint ed., l vol. Hildesheim: 0lms, 1970.

Klarinetten Duette aus der Fruhzeit des Instrumentes. Ed. Heinz Becker. Collegium Nusicum, no. 106. Wiesbaden: Breitkopf \& Hätel, 1954.

Kroll, Oskar. The Clarinet. Rev and with a repertory by Diethard. Piehm, trans. by Hilda Morris, trans. ed. by Anthony Baines. New York: Taplinger, 1968.

[La Borde, Jean-Benjamin de]. Essai sur la rnusique ancienne et moderne. 4 vols. Faris: Fh.D. Pierres, 1780.

Lefevre, Jean-Kavier. Méthode de Clarinette. Paris: Imprimerie du Conservatoire, 1802 .

The Letters of Mozart and His Family. Trans. and ed. by Emily Anderson. 4 vols. London: Macmillan \& Co., 1938.

Luscinius, Ottmar. Musurgia seu praxis Musicae. Strasburg: Joannem Schottum, 1536.

Wajer, Joseph Friedrich Bernhard Caspar. Museum Musicum Theoretico Practicum das ist Neu-erbffneter Theoretisch-und Practischer Nusic-Saal. Schwab. Hall: Georg Michael Majer, 1732; Documenta Musicologica, vol. 8, facsimile ed., ed. by Heinz Becker. Kassel und Basel: BHrenreiter, 1954. 
Vajer, Joseph Friedrich Bernhard Caspar. Neu-eryffneter theoretischer Husic-Saal. Nurnberg: Johann Jacob Gremer, 1741.

Harcuse, Sibyl. A Survey of "usical Instruments. New York: Harper \&: Row, 1975.

Mattheson, Johann. Grundlage einer Ehren-Pforte. Hamburg, 1740; reprint ed., ed. by Max Schneider. Kassel: Burenreiter, 1969.

Menke, Werner. Das Vokalwerk Georg Philipp Telemann's. Kassel: Bürenreiter, 1942.

Mersenne, Marin. Harmonie universelle, contenant la theorie et la pratique de la musique. Paris, 1636; facsimile ed., intro. by Fronçois Lesure. Faris: Ed. du Centre National de la Recherche Scientifique, 1963.

- Harmonie Universelle. Paris: S. Cramoisy, 1636. The Boolss on Instruments. Trans. by Roger E. Chapman. The Hague: Martinus Nijhoff, 1957.

Die Musik in Geschichte und Gegenwart Allgemeine Enzyklophdie der Musik. Ed. Friedrich Blume. Kassel und Basel: Burenreiter, 1949-.

Newman, Hilliam S. The Sonata in the Classic Era. Chapel Hill: University of North Carolina Press, 1963.

Nickel, Ekzehart. Der Holzblasinstrumentenbau in der Freien Reichsstadt Nurnberg. Schriften zur Musik, vol. 8. Munchen: Emil Katzbichler, 1971. 
Nicot, Jean. Thresor de la Langue Francoise tant ancienne que moderne. Paris: David Davieur, 1606; reprint ed. Jenston, England: ;colar Fress, 1972.

Petzoldt, Richard. Georg Philipp Telemann=Leben=und Werk. Leipzig: VEB Deutscher Verlag fur musik, 1967.

Fincherle, Miarc. Antonio Vivaldi et la Musique Instrumentale. 2 vols. Faris: Libraire Floury, 1948. - Vivaldi, Genius of the Baroque. Trans. by Christopher Hatch. New York: W.W.Norton, 1957.

Praetorius, Michael. Syntagma musicum: II. De Organographia. Wolffenbuttel: Elias Holwein, 1619; Documenta Musicolocica, vol. 14, facsimile ed., ed. by Wilibald Gurlitt. Kassel: Bürenreiter, 1958.

Pulver, Jeffrey. A Dictionary of Old English Music \& Musical Instruments. New York: E.P. Dutton \& Co., 1923.

Pendall, F. Geoffrey. The Clarinet, some notes upon its history and construction. $3 d$ ed. revised with some additional material by Thilip Bate. New York: W.W. Norton, 1971.

Reynvaan, Joos Verschuere. Muzikal Kunst-woordenboek. Amsterdam: Vouter Brave, 1795.

Roeser, Valentin. Essai d'Instruction à l'usage de ceux qui composent pour la clarinette et le cor. Paris: Mercier, 1764 Amand Vanderhagen. Méthode Nouvelle et Raisonnée pour la Clarinette. Paris: Boyer et Le Menu, 1798 [c. 1785]; reprint ed. in 1 vol. Geneve: Minkoff Reprint, 1972. 
Sachs, Curt. The History of Musical Instruments. New York: W.W. Iorton, 1940.

Smith, Villiam C. A Bibliography of the Nusical Vorks Fublished by John Walsh During the Years 1695-1720. London: Bibliographical Society at the University Press, Oxford, 1948.

Straeten, Fdmond van der. Ia Fusique aux Fays-Bas Avant le XIX siècle. \& vols. Bruxelles: C. Muquart, 1867-1888; reprint ed., 4 vols. New York: Dover, 1969.

Trichet, Fierre. Traité des instruments de musique (vers 1640). Intro. and notes by François Lesure. Neuilly-sur-Seine: Société de musique d'autrefois, 1957.

Vandenbrock, Othon. Traité général de tous les instrumens à vent. Paris: Boyer, 1793.

Virdung, Sebastian. Musica getutscht und auszgezogen. Basel:

Yilhalmen Bischoue, 1511; Publikationen Hlterer praktischer und theoretischer Nusikwerke, vol. 1l, facsimile ed. Berlin: Gesellschaft fur Wusikforschung unter Leitung Robert Eitner, 1883; reprint ed. Kassel: Burenreiter, 1931.

Walther, Johann Gottfried. Musikalisches Lexicon oder musicalische Bibliothek. Leipzig: Wolffgang Deer, 1732; Documenta Musicologica, vol. 3, facsimile ed., ed. by Richard Schaal. Kassel: Bürenreiter, 1953.

- Praecepta der musicalischen Composition. (1708); Jenaer Beitrage zur musikforschung, vol. 2, facsimile ed., ed. by Peter Benary. Leipzig: Breitkopf \& Hurtel, 1955. 
Harner, Thomas E. An Annotated Bibliography of Hoodwina 183 $\frac{\text { tion Books, 1600-1830. Detroit: Information Coordinators, }}{\text { Inc., } 1967 .}$

Teigle, Johann Christoph. Musicalisches Theatrum auf welchen alle zu dieser edlen zunst eehurige Instrumenta. vurnberg: Joh. Christoph Feigle, c. 1726; Documenta Musicologica, vol. 22, facsimile ed., ed. by Alfred Berner. Kassel: Burenreiter, 1961.

Veston, Pamela. Clarinet Virtuosi of the Past. Iondon: Robert Hale, 1971.

The Vorld Book Encyclopedia. 20 vols. Chicago: Field Enterprises Educational Corporation, 1961.

Zedler, Johann Heinrich. Grosses vollstandiges Universal-Lexicon. 33 vols. Halle und Leipzig: Verlegts J.H. Zedler, 1732-1754. 
Articles

Becker, Heinz. "Das Chalumeau bei Telemann," Konferenzbericht der

3. Magdeburger Telemann-Festtace vom 22. bis 26. Juni 1967.

$2 d$ part, editing, Gunter Fleischhauer und walter Siegmund-

Schultze (Macdebure: Deutsche Kulterbund, 1969): 68-76.

"Das Chalumeau im 18. Jahrhundert," Speculum Musicae

Artis. Festgabe fur Heinrich Husmann zum 60. Geburtstag

(Mituchen: Tilhelm Fink, 1970): 23-46.

- "Zur Geschichte der Klarinette im 18. Jahrhundert,"

Die Musikforschung 8 (1955): 271-292.

Bowles, Edmund. "Haut and Bas: The Grouping of Musical Instruments in the Iiddle Âges," Musica Disciplina 8 (1954): 115140 .

Brenet, Michel. "Pameau, Gossec et les clarinettes," Le Guide Wusicale 49, no. 9 (March 1 1903): 183-185; 49, no. 10 (March 8 1903): 203-205; 49, no. 11 (March 15 1903): 227-228.

Chatwin, R.B. "Handel and the Clarinet," Galpin Society Journal $3($ Iarch 1950): 3-8.

Cucuel, Georges. "La question des clarinettes dans l'instrumentation du XVIII ${ }^{\mathrm{e}}$ siecle," Zeitschrift der Internationalen lusikgesselschaft 12 , no. 10 (July 1911): 280-284.

Dart, Thurston. "Handel and the Clarinet," Musical Times 90 , no. 1317-1318 (Nov-Dec 1952): 510.

- "The Earliest Collections of Clarinet Music," Galpin Society Journal 4 (June 1951): 39-41. 
Dart, Thurston. "The Mock Trumpet," Galnin Society Journal 6 (July 1953): 35-40.

Fitzratrick, Forace. "Jacob Denner's Voodwinds for Gottweig Abbey," Galpin Society Journal 21 (Yarch 1968): 81-87.

Gossec, François-Joseph. "Notice sur l'introduction des cors, des clarinettes et des trombones dans les orchestres franģais; extraite des manuscripts autographes de Gossec," Revue rusicale (of Fétis) 3d year, 5 (1829): 217-223.

Gradenwitz, Feter. "The Beginnings of Clarinet Literature," Pusic and Letters 27, no. 2 (April 1936): 145-150.

Halfpenny, Eric. "Castillon on the Clarinet," Music and Letters 35, no. 4 (October 1954): 332-338.

Heyde, Ferbert. "Sin Urahn der Klarinette?" Deutsches Jahrbuch der Musikwissenschaft fur 197015 (1971): 121-124.

Hunt, Edgar. "Some Light on the Chalumeau," Galpin Society Journal 14 (Narch 1961): $41-44$.

Kirkpatrick, Ralph. "On re-reading Couperin's L'Art de Toucher le Clavecin," Early Music 4 (January 1976): 3-4.

Kolneder, Valter. "Die Klarinette als Concertino-Instrument bei Vivaldi," Die Musikforschung 4 (1951): 185-191.

"Noch einmal: Vivaldi und die Klarinette," Die Musikforschung 8 (1955): 209-211.

Kroll, Oskar. "Das Chalumeau," Zeitschrift fur Musikwissenschaft 15, no. 8 (riay 1933): 374-378. 
Laurencie, Lionel de La. "Remeau et les Clarinettes," Sammelbunde der Internationalen Musikgessellschaft 9 , no. 2(February 1913): 27-28.

Lawson, Colin. "The ت̈arly Chalumeau Duets," Galpin Society Journal 27 (April 1974): 125-129.

MGG (1958), s.v. "IMrinette: C. Die europlische Klarinette," by Heinz Becker, 7: cols. 1005-1027; English trans. by Dyke Kiel, The Clarinet 2, no. 3 (May 1975): 5-10; 2, no. 4 (August 1975): $23-24$.

Owen, Ingela Maria. "The Chalumeau and Its liusic," American Recorder 5, no. 1 (1967): 7-9.

Frod'Homme, Jacques-Gabriel. "Austro-German Musicians in France in the Eiphteenth Century," The Musical Quarterly 15, no. 2 (1929): 171-195.

Rendall, F. Geoffrey. "A Short Account of the Clarinet in England during the Eighteenth and Iineteenth Centuries," Proceedings of the Royal Musical Association, 68th Session (1941-42): 5586.

Scott, Maxyne Mathisen. "The Clarinet in France in the Mid-18th Century," National Association of College Wind and Percussion Instructors Journal 20, no. I (Fall 1971): 14-16.

Simpson, Adrienne. "A Short-title list of printed English Instrumental tutors up to 1800 held in British libraries," R.M.A. Research Chronicle no. 6 (1966): 24-50.

Thaler, Alan. "Der Getreue Music-Meister: A 'Forgotten' Periodical," The Consort 24 (1967): 280-293. 
Tilmouth, Michael. "A Calendar of References to Music in Newspapers published in Iondon and the Provinces (1660-1719)," R.1..A. Research Chronicle no. 1 (1961, reprint 1968): 1-54.

Van der Meer, John Henry. "Some More Denner Guesses," Galpin Society Journal 23 (August 1970): 117-119.

"The Chalumeau Problem," Galpin Society Journal 15 (March 1962): 89-91.

Whitwell, David. "Early Clarinet Nanuscripts in Vienna," Instrumentalist 25, no. 4 (November 1970): 38-39.

Nolf, Eugene K. and Jean K. "A Nevly Identified Complex of Manuscripts from Mannheim," Journal of the American Musicological Society 27 (Fall 1974): 379-437.

Young, Phillip T. Moodwind Instruments by the Denners of Nurnberg," Galrin Society Journal 20 (March 1967): 9-16. 


\section{Unpublished materials}

Airs à Deux Chalumeaux Deux Trompettes, deux Haubois, deux Violons, deux Flutes, deux Clarinelles, ou Cors de Chasse. Dediez à Monsieur Henry Iperman Docteur en droit Civil \&: en droit Canon. Livre Fremier, Amsterdam: Estienne Roger \& Le Cene, c. 1717 to 1722 .

Becker, Heinz. "Zur Geschichte der Klarinette im 18. Jahrhundert," Die Musikforschung 8 (1955): 271-292; English trans. by Don Halloran (August 1971, typewritten).

Bill, Oswald. Hessische Landes-und Hochschulbibliothek. Listings of chalumeau and clarinet music. Personal letter 11 January 1974 .

Bogart, Daniel Thomas. "A History of the Clarinet as an Orchestral Instrument from Inception to Full Acceptance into the Woodwind Choir". Ph. D. dissertation, Michigan State University, 1968.

Brook, Barry S. "Roeser, Valentin". 7 pages to be published in Groves VI. Personal letter 8 January 1976.

Callcott, John Wall. "Clarinett". Article from an unpublished Dictionary of Music (1797-1807), London, British Library, Add. 27680 .

Lanning, Edward Francis. "The Clarinet as the intended solo instrument in Johann Melchior Molter's Concerto 34". D.M.A. dissertation, University of Missouri-Kansas City, 1969. 
Ludewig, Elsa Marie. "A Study of Zublished Clarinet Concertos before the Nozart Clarinet Concerto". Y.A. thesis, Iniversity of Rochester-Eastman school of vusic, 1963.

MGG (1958), s.v. "Klarinette: C. Die europdische Klarinette," by Heinz Becker, 7: cols. 1005-1027; English trans. by Dyke Kiel (December 1973, tyrewritten).

Macdonald, Robert James. "François-Joseph Gossec and French Instrumental Kusic in the jecond lalf of the eighteenthcentury". 2 vols. Th. D. dissertation, University of Michigan, 1968.

Owen, Angela Marie. Information on music written for the chalumeau. Personal letter 31 Narch 1977.

Rousseau, Eugene E. ""Clarinet Instructiona]. Saterials from 173 ? to CA. 1825". Fh. D. dissertation, State Iniversity of Iowa, 1962.

The Fourth Compleat Book for the Yock Trumpet . . London: J. Walsh, J. Hare and F. Randall, c. 1707.

Titus, Robert Austin. "The Solo Kusic for the clarinet in the eighteenth century". Fh. D. dissertation, State University of Iowa, 1962.

Warner, Thomas Everett. "Indications of Ferformance Fractise in Woodwind Instruction Books of the 17th and 18.th Centuries". Fh. D. dissertation, INew Yor!: University, $19,64$. 